\title{
FormaÇÃo de Biofilme e CorRosão em APARELHOS DiSJUNTORES de HaAs, Com e Sem Utilização de Agente Antimicrobiano: ESTUDO IN SITU.
} Dissertação apresentada à Faculdade de Odontologia de Ribeirão Preto da Universidade de São Paulo, para a obtenção do título de Mestre em Odontopediatria.

Orientador: Prof. Dr. Paulo Nelson-Filho

Ribeirão Preto-SP 


\section{FICHA CATALOGRÁFICA}

Bagatin-Rossi,Cristhiane Ristum

Formação de biofilme e corrosão em aparelhos disjuntores de Haas, com e sem utilização de agente antimicrobiano: estudo in situ. Ribeirão Preto, 2007.

89. : il. ; $30 \mathrm{~cm}$

Dissertação de Mestrado, apresentada à Faculdade de

Odontologia de Ribeirão Preto/USP. Área de concentração:

Odontopediatria.

Orientador: Nelson-Filho, Paulo.

1. Biofilme dental. 2. Estreptococos do Grupo Mutans. 3. Corrosão. 4. Disjuntores. 5. Clorexidina. 


\section{FormaçÃo de Biofilme e Corrosão em Aparelhos Disjuntores de haAs, Com e Sem Utilização de Agente Antimicrobiano:}

\section{ESTUDO IN SITU.}

Dissertação apresentada à Faculdade de Odontologia de Ribeirão Preto da Universidade de São Paulo, para a obtenção do título de Mestre em Odontopediatria.

Aprovado em:

Banca Examinadora

Prof. Dr.

Instituição: Assinatura:

Prof. Dr.

Instituição: Assinatura:

Prof. Dr. Instituição: Assinatura: 


\section{DADOS CURRICULARES}

\section{CRISTHIANE RISTUM BAGATIN-ROSSI}

Nascimento

18 de fevereiro de 1977 - Ribeirão Preto/SP

Filiação

Luis Antônio Bagatin

Marisa Dieb Ristum Bagatin

1995-1998

Curso de Graduação

Universidade de Ribeirão Preto - UNAERP

1998-1999

Curso de Aperfeiçoamento no Atendimento

Odontológico a Pacientes Especiais

Universidade de Ribeirão Preto - UNAERP

2000-2002

Curso de Homeopatia

Instituto Homeopático François Lamasson Ribeirão Preto/SP

2003-2004

Especialização em Odontopediatria

Universidade de Ribeirão Preto - UNAERP

2005

Curso de Aperfeiçoamento no Atendimento

Odontológico a Pacientes Especiais

Faculdade de Odontologia de Ribeirão Preto - USP

2005-2007

Curso de Pós-graduação (Mestrado) em Odontologia

Área de Concentração: Odontopediatria

Faculdade de Odontologia de Ribeirão Preto - USP 


\section{Ofereço este Trabalho}

A Deus,

"O teu presente éo presente que Deus Ihe entrega. Este éo momento para que você seja tudo o que precisa ser. Faça sua parte e com certeza Deus faráa dele pois, na realidade, todas as coisas, todos os acontecimentos, para quem os sabe ler com profundidade, encerram uma mensagem que, em definitivo, remete para Deus".

(João Paulo II) 


\section{Aos meus pais,}

A vitória alcançada hoje é fruto do amor incondicional desta união em minha vida. Vocês são o referencial, o exemplo e o meu melhor.

Ao meu pai Luis Antônio Bagatin, por me ensinar a ser melhor a cada dia, você é meu apoio, base e proteção. Subsidiando minhas escolhas incondicionalmente, me faz entender o verdadeiro sentido de amar.

À minha mãe Marisa Dieb Ristum Bagatin, que me ensinou os valores da responsabilidade, da dedicacão e da competência, despertando o que há de melhor em mim. Incentivo constante para o meu crescimento profissional e pessoal, aqui está mais uma conquista por você estimulada.

Ao meu marido Leandro Bielli Rossi, responsável direto por esta conquista. É por você e para nós que cheguei até aqui. Obrigada por me provar que seu amor não tem limites, estando ao meu lado, me amparando e me impulsionando a cada nova dificuldade. A você minha gratidão e o meu amor, por todos os dias de minha vida.

A toda a minha familia, em especial às minhas tias Salma, Nadima, Célia e Adiná (in memorian) por estarem comigo, em constante apoio, afeto e presença, suprindo minhas vontades e aceitando minhas escolhas. Que essa conquista seja motivo de orgulho para vocês.

À minha nova familia Rossi, em especial à minha cunhada Ana Paula e à Ana Maria, pelas alegrias e bons momentos que tivemos, tornando minhas dificuldades mais leves. Agradeço a todos que compreenderam minhas ausências e falhas durante essa jornada. 
Ao meu orientador Prof. Dr. Paulo Nelson-Filho,

Pelo privilégio de ter sido guiada por um verdadeiro Mestre. Pessoa que dignifica a especialidade da Odontopediatria, com a vocação de ser Professor e Pesquisador. Inümeras são suas qualidades, com ações inspiradoras, atitudes e ensinamentos essenciais. Com uma convivência pautada no respeito e grande afeição, transformou minhas angüstias em possibilidades, minhas possibilidades em oportunidades e, hoje, minhas oportunidades se tornam realização. Meu reconhecimento e gratidão por ter sido escolhida sua orientada. $\mathrm{Na}$ certeza de que minha caminhada não termina aqui, levo comigo seu amor à profissão e a valorização da seriedade quando se gera o conhecimento científico, como condicốes para o meu exito profissional e pessoal. Muito Obrigada.

\section{À Profi. Dra. Izabel Yoko Ito,}

Pela honra de me permitir compartilhar de sua imensa sabedoria e bondade. Pessoa que me impressionou com sua incansável dedicacão à pesquisa e me inspirou com seu dinamismo e perseverança. Fą̧o minhas as palavras de William M. Bulger: "Não há nada que melhor defina uma pessoa do que aquilo que ela faz quando tem toda a liberdade de escolha".

\section{Ao Prof. Dr. José Tarcísio Lima Ferreira,}

Pelo vínculo criado por meio da convivência no desenvolvimento deste trabalho. Sua colaboração com disponibilidade, atenção e paciência frente às minhas ansiedades me ensinou que ser professor é acima de tudo compreender. Meus sinceros agradecimentos. 
À Coordeną̧ão do Programa de Pós-Graduação em Odontopediatria da Faculdade de Odontologia de Ribeirão Preto da Universidade de São Paulo, na pessoa da coordenadora Prof. Dra. Léa Assed Bezerra da Silva e do Vice-Coordenador Prof. Dr. Paulo NelsonFilho, pela oportunidade de participar deste conceituado Programa de Pós-graduação, me permitido vislumbrar perspectivas diferentes para minha vida.

À Prof. Dra. Sada Assed, Vice-Diretora da Faculdade de Odontologia de Ribeirão Preto da Universidade de São Paulo e à Prof. Dra. Aldevina Campos de Freitas, exemplos de vida e excelência acadêmica dedicada ao Departamento de Clinica Infantil, Odontologia Preventiva e Social da Faculdade de Odontologia de Ribeirão Preto-USP.

À Profi. Dr Léa Assed Bezerra da Silva, cujo comprometimento com o Ensino se estende além da carreira acadêmica, com dignidade e competência incontestäveis, minha admirą̧ão.

Ao Prof. Dr. Mário Leonardo, professor e pesquisador renomado mundialmente. Realidade tão distante que se fez tão próximo em inümeros momentos, inspirando-me com seu altruismo intelectual. Verdadeiro mestre por vocacão, meu mais profundo respeito.

À Prof́. Dr. Maria Conceição Pereira Saraiva, pelo valioso auxilio e orientação na anălise estatistica dos resultados, não medindo esforços para me auxiliar. Seus ensinamentos foram mais do que acadêmicos. Muito obrigada.

Ás docentes Prof. Dr. Maria Cristina Borsatto, Prof. Alexandra Mussolino de Queiroz e Prof. Dr. Kranya Victória Diazz Serrano, pela transmissão de conhecimentos no decorrer do curso e pela convivência e apoio constante, que tornou possível uma maior proximidade entre nós. Meu afeto sincero. 
À pós-graduanda Marcela Cristina Damião Andrucioli Soato, pela participação direta no atendimento aos pacientes participantes deste trabalho, abracando minha causa como se fosse sua. Você foi exemplo de doação, dedicando-se com responsabilidade, competência e profissionalismo. Esta vitória é sua também.

À pós-graduanda Juliana Barreto de Souza, por ter compartilhado comigo seus pacientes. Pela cumplicidade, disposição, apoio e companhia constantes, mostrando-me a cada dia que a verdadeira sabedoria está na bondade. Obrigada por tudo.

À professora Profa. Dra. Regina Guenka Palma Dibb, pela contribuicão na realização das fotografias em estereomicroscópio. Agradeço a disponibilidade e gentileza.

Aos docentes do Departamento de Clinica Infantil, Odontologia Preventiva e Social da Faculdade de Odontologia de Ribeirão Preto-USP, Profa. Dra. Sada Assed, Profa. Dra. Aldevina Campos de Freitas, Profa. Dra Léa Assed Bezerra da Silva, Prof. Dr. Mário Leonardo, Prof. Dr. Paulo Nelson-Filho, Profa. Dra. Maria Cristina Borsatto, Prof́. Alexandra Mussolino de Queiroz, Profa. Dra. Kranya Victória Diaz Serrano, Dra Gisele Faria, Profi. Dra. Maria Conceição Pereira Saraiva, Prof. Dr. Adilson Thomazinho, Prof. Dr. José Tarcisio Lima Ferreira, ,Profa Dra. Mirian Aiko Nakane Matsumoto e Profa Dra. Maria Bernadete Sasso Stuani, por dividirem comigo seus conhecimentos, pelo incentivo e pela convivência. Meu respeito e gratidão.

Ao Prof. Dr. Cincinato Rodrigues silva Neto, que acreditou em minha capacidade, ainda no primeiro ano de Faculdade, me incentivando a seguir na área acadêmica. Mestre, essa vitória representa o seu dom em minha vida.

Aos meus professores de graduação em Odontopediatria da UNAERP, Prof Dra Delsa Deise Macchetti Kanaan, Prof Christiane Elen Barquete Grandini Zuccolotto, Prof Dra Yara Teresinha Correa da Silva-Souza, Prof Dra Maria Célia Tambasco de Oliveira, Prof. Dr. Luís José Florian e Prof. Dr. Vlamir Oliveira da silva. Vocês foram o alicerce e a inspiração. obrigada por me ensinarem, através de suas atitudes, que dedicação à profissão podem ser somadas à afeição e ternura pelos alunos e pacientes. Meu eterno carinho e amizade. 
À pós-graduanda e amiga Raquel Assed Bezerra da silva, grande incentivadora desta nova trajetória da minha vida. Exemplo de responsabilidade, dedicação e competência, tenho orgulho de ser sua amiga. Conte sempre comigo. Registro aqui meu carinho e gratidão a você.

À pós-graduanda e amiga Regina Aparecida Segato Saiani, pelo inicio de uma grande amizade nas dificuldades compartilhadas. Pelas palavras de incentivo fundamentais nos momentos dificeis, com cumplicidade e afeto. Você é para mim um grande exemplo de responsabilidade e, acima de tudo, competência e profissionalismo. Muito obrigada.

À querida pós-graduanda Maria Stella Gaspar Gomes Raffaini, pela parceria e ajuda incondicionais durante toda esta jornada. Minha admiracão e gratidão, com muito carinho. Sua disposição, apoio e dedicacão constantes mostram o grande ser humano que é.

Aos colegas de Pós-Graduação, Cristiane Tomaz Rocha, Iza Teixeira Alves Peixoto, Maria Stella Gaspar Gomes Raffaini, Patricia Maria Monteiro, Patricia Motta Fernandes, Regina Aparecida Segato Saiani, Thaís Helena Andreolli do Amaral, Adriana Sasso Stuani, Fumio Matoba Junior e Valéria Pontelli Navarro, Soraia Monique Fiorati Aguiar, Sara Elisa Medina Mattar, Maria Angélica H. de M. Oliveira, pelos bons momentos compartilhados. Especialmente à Jaciara Gomes Miranda Silva, Soraya Dibb Sheyer Goncalves, Carolina de Souza Guerra, Francisco Wanderley Garcia de Paula e Silva e Andréa Soares de Oliveira Ortolan, pela disposição, ajuda e amizade demonstradas desde o inicio, em todos os momentos que convivemos.

Aos funcionários do Departamento de Clínica Infantil, Odontologia Preventiva e Social da Faculdade de Odontologia de Ribeirão Preto da Universidade de São Paulo, Fătima Aparecida Jacinto Daniel, Marco Antônio dos Santos, Nilva Aparecida Afonso Ruggiero, Rejane Gomes Cavalheiro Mazer e Carmo Euripedes Terra Barreto. Pela eficiência em 
atender e ajudar, sempre fazendo o melhor para corresponder às necessidades de todos e, sobretudo, pela amizade e carinho que me ofereceram.

Aos funcionários da Clínica I, do Departamento de Clínica Infantil, Odontologia Preventiva e Social da Faculdade de Odontologia de Ribeirão Preto da Universidade de São Paulo, Cleber Barbosa Rita, Vera Ribeiro do Nascimento e José Aparecido Neves do Nascimento, por sempre fazerem o melhor para corresponder às minhas necessidades durante o atendimento aos pacientes. Pela simpatia e empenho em me ajudar, fundamentais em muitos momentos.

Aos funcionários do "Centro de Formação de Recursos Humanos Especializados no Atendimento Odontológico de Pacientes Especiais", Benedita Viana Rodrigues, Fátima Rizóli, Nadir Felício e Renata Aparecida Fernandes Rodrigues, pelo atendimento sempre eficiente e cordial, especialmente à CD. Carolina Paes Torres Mantovani, pela amizade e carinho com que me acolheu nos momentos angustiantes.

Ás secretárias da Seção de Pós-Graduação Isabel Cristina Galino Sola e Regiane Cristina Moi Sacilotto, pela cordialidade, atenção e paciência em todos os momentos.

Ao funcionário Carmo Euripedes Terra Barreto, responsável pela confeção dos aparelhos utilizados neste trabalho. Minha profunda gratidão pelas orientaçôes, paciência, atenção e boa vontade.

Ao Departamento de Análise Clínicas, Toxicológicas e Bromatológicas da Faculdade de Ciências Farmacêuticas de Ribeirão Preto-USP, em especial ao pós-graduando Evandro Watanade e à técnica Maraisa Palhão Verri, pela assistência imprescindivel, pela atenção, gentileza e pela contribuicão no processamento microbiológico.

À técnica do laboratório de Microscopia Eletrônica de Varredura da Faculdade de Ciências Agrârias e Veterinárias de Jaboticabal da Universidade Estadual Paulista, Cláudia Aparecida 
Rodrigues, pela inestimável colaboração no processamento das amostras com atenção e disponibilidade.

Ao técnico do laboratório de Microscopia da Faculdade de Filosofia, Ciências e Letras de Ribeirão Preto - Departamento de Química da Universidade de São Paulo, Luciano Andrey Montoro, pela disponibilidade, atenção e paciência na avalią̧ão das amostras.

À Regina Aguena Albuquerque, Hermano Teixeira Machado e Júlio César de Matos, pelo auxilio nas ilustraçôes deste trabalho.

Aos Pacientes e seus acompanhantes, que tornaram este trabalho realidade, a minha gratidão pela confiança depositada e pelo carinho tantas vezes demonstrado.

Aos Alunos de Graduacão (Turmas 77, 78 e 79), pelo respeito e amizade que desenvolvemos durante estes anos, na convivência e confiança que muitas vezes nos aproximou.

À CAPES - Coordeną̧ão de Aperfeiçoamento de Pessoal de Nível Superior, pelo apoio e incentivo à pesquisa brasileira, buscando a excelência de nossa Pós-Graduação. Pelo fomento, indispensâvel ao desenvolvimento deste trabalho.

À FAPESP - Fundacão de Amparo à Pesquisa do Estado de São Paulo, pelo auxīlio financeiro, sem o qual esta conquista não seria possivel.

A todos que, de alguma forma, contribuiram para a realização deste trabalho, minha lembrança e minha gratidão. 


\section{RESUMO}

BAGATIN-ROSSI, CR. Formação de biofilme e corrosão em aparelhos disjuntores de Haas, com e sem utilização de agente antimicrobiano: estudo in situ. Ribeirão Preto, 2007. 89p. Dissertação [Mestrado] - Faculdade de Odontologia de Ribeirão Preto, Universidade de São Paulo.

O objetivo do presente estudo foi avaliar, em aparelhos disjuntores de Haas, a contaminação in situ por estreptococos do grupo mutans, sob a forma de colônias/biofilmes, nas diferentes superfícies (acrílico, fios, bandas e parafusos), com e sem o uso de bochechos com gluconato de clorexidina a 0,12\%, por meio de Cultura Microbiana e Microscopia Eletrônica de Varredura (MEV). Adicionalmente, a corrosão na área da união entre o fio, a solda de prata e a banda dos aparelhos foi avaliada por meio de Estereomicroscopia Ótica, MEV e análise em Espectrometria de Energia Dispersiva (EDS). Foram selecionados 34 pacientes de 7 a 12 anos de idade, que compareceram à clínica de Ortodontia Preventiva da FORP/USP, com necessidade de correção com aparelho disjuntor de Haas por problemas transversais da maxila (mordida cruzada posterior). Em seguida, utilizando uma tabela de números randômicos, os pacientes foram aleatoriamente divididos em dois grupos de 17 indivíduos cada (Grupos I e II). Durante todo o período de permanência dos aparelhos na cavidade bucal, no Grupo I (controle; $n=17$ ) os pacientes foram orientados a utilizar dentifrício fluoretado para escovação diária e não empregar bochechos com soluções antimicrobianas. Por outro lado, no Grupo II (experimental; $n=17$ ) os pacientes foram orientados a realizar, além da escovação diária com o uso de dentifrício fluoretado, 2 bochechos por semana com solução de gluconato de Clorexidina a $0,12 \%$ (Periogard ${ }^{\circledR}$ ). Decorridos cerca de 4 meses da permanência na cavidade bucal, os aparelhos foram removidos. Sendo seccionadas, aleatoriamente, partes dos aparelhos constituídas de uma banda com fio soldado, para análise em estereomicroscopia ótica, MEV e EDS. Os resultados em estereomicroscopia foram submetidos à análise estatística por meio do teste de Fisher, com nível de significância de 5\%. Em seguida, os aparelhos foram submetidos ao processamento microbiológico, em meio de cultura CaSa B, para contagem das colônias/biofilmes de estreptococos do grupo mutans. O teste estatístico não-paramétrico de Mann-Whitney foi aplicado para verificação de possíveis diferenças entre os grupos, com relação à formação de colônias/biofilmes sobre a superfície das diferentes áreas (parafuso, resina acrílica, bandas, fio vestibular e fio palatino), como também para verificar se havia diferença entre a formação de colônias/biofilmes sobre as superfícies livres (voltadas para a cavidade bucal) e as superfícies não-livres (em contato direto com a mucosa palatina e sulco gengival). O nível de significância adotado foi de 5\%. Após cultura microbiana, partes dos aparelhos 


\section{Abstract}

BAGATIN-ROSSI, CR. Biofilm formation and corrosion in Haas expanders, with and without use of an antimicrobial agent: in situ study. Ribeirão Preto, 2007. 89p. Dissertação [Mestrado] - Faculdade de Odontologia de Ribeirão Preto, Universidade de São Paulo.

The purpose of this study was to evaluate, in situ, in Haas expanders, the contamination of different surfaces (acrylic resin, wires, bands and screws) by mutans group streptococci colonies/biofilms with and without prescription of $0.12 \%$ chlorhexidine gluconate mouthwashes, by means of microbial culture and scanning electron microscopy (SEM). Additionally, the corrosion in the area of union between the appliances' wire, silver soldering and band was assessed by optical stereomicroscopy, SEM and energy dispersive spectroscopy (EDS). Thirty-four children aged 7 to 12 years were selected among the patients attending the Preventive Orthodontic Clinic at FORP/USP with need of corrective orthodontics with Haas expander due to transversal problems of the maxilla (posterior crossbite). Thereafter, using a table of random numbers, the patients were randomly assigned to two groups of 17 individuals each (Groups I and II). Throughout the time that the appliances remained in the oral cavity, the patients in Group I (control; $n=17$ ) were instructed to use a fluoridated dentifrice for daily toothbrushing and not to use antimicrobial mouthwash solutions. On the other hand, in Group II (experimental; $n=17$ ), in addition to daily toothbrushing with a fluoridated dentifrice, mouthwashes with an antimicrobial agent $\left(0.12 \%\right.$ chlorhexidine gluconate - Periogard $\left.{ }^{\circledR}\right)$ were prescribed to the patients. After approximately 4 months of maintenance in the patients' mouth, the appliances were retrieved. Thereafter, components of the appliances (consisting of a band with soldered wire) were sectioned at random for analysis under optical stereomicroscopy, SEM and EDS. The results of the optical stereomicroscopy were submitted to statistical analysis using Fisher's test at $5 \%$ significance level. The appliances were sent to microbiology processing, in CaSa B culture medium, for counting of the number of mutans streptococci colonies/biofilms. Mann-Whitney non-parametric statistical test was applied to verify possible differences between the groups with respect to the formation of colonies/biofilms on the surface of different areas (screw, acrylic resin, bands, buccal wire and palatal wire), as well as to determine whether there were differences between the formation of colonies/biofilms on free surfaces (facing the oral cavity) and non-free surfaces (in direct contact with the palatal mucosa and gingival sulcus). The level of significance was set at 5\%. After microbial culture, components of the appliances that were representative of each group were 
submitted technical processing and SEM analysis. The obtained results showed that there was no statistically significant difference between Groups I and II $(p=0.009)$ regarding the formation of colonies/biofilms on the non-free surfaces. However, when the free surfaces of Groups I and II were compared, statistically significant difference was observed between these groups in all analyzed areas (screw, acrylic resin and bands) $(p<0.001)$. The results of the microbial culture were confirmed by the SEM analysis. The optical stereomicroscopic analysis showed the existence of color alteration suggestive of corrosion in the solder region in contact with the band and with the wire in both groups $(p=1)$. The peaks of chemical elements observed in EDS were also similar in both groups. It may concluded that the use of $0.12 \%$ chlorhexidine gluconate mouthwashes (Periogard ${ }^{\circledR}$ ) showed efficacy in reducing the formation of colonies/biofilms on the free surfaces of Haas expanders, in situ, without increasing the corrosion levels.

Key Words: Dental biofilm, Mutans Streptococci, Corrosion, Expanders, Chlorhexidine. 
representativas de cada grupo foram submetidas ao processamento e análise em MEV. Os resultados obtidos evidenciaram que, com relação às colônias/biofilmes das superfícies nãolivres dos Grupos I e II, não houve diferença entre os grupos $(p=0,009)$. No entanto, quando as superfícies livres dos Grupos I e II foram comparadas, evidenciou-se diferença significante entre os 2 grupos, em todas as áreas analisadas (parafuso, resina acrílica e bandas) $(p<0,001)$. Os resultados da cultura microbiana foram confirmados em MEV. A análise em estereomicroscopia ótica evidenciou a presença de áreas de alteração de coloração sugestivas de corrosão na região de solda em contato com a banda e com o fio, em ambos os grupos $(p=1)$. Os picos dos elementos químicos observados em EDS também foram semelhantes em ambos os grupos. Pôde-se concluir que o uso do gluconato de clorexidina a $0,12 \%$ (Periogard ${ }^{\circledR}$ ), sob a forma de bochecho, apresentou eficácia na redução da formação de colônias/biofilmes nas superfícies livres dos aparelhos disjuntores de Haas, in situ, sem elevação nos níveis de corrosão.

Palavras-chave: Biofilme dental, Estreptococos do grupo mutans, Corrosão, Disjuntores, Clorexidina. 


\section{SUMÁRIO}

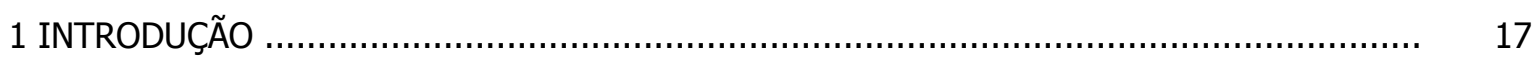

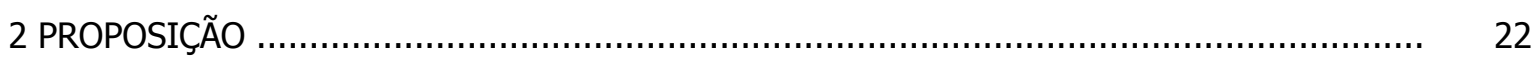

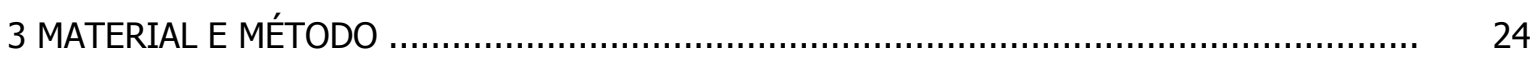

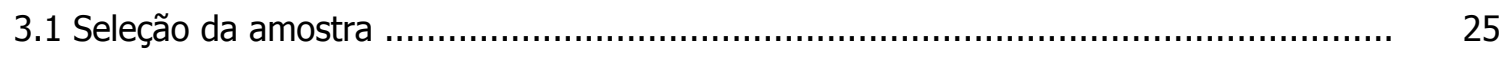

3.2 Colheita e Processamento de amostras de saliva .................................................. 25

3.3 Confecção dos aparelhos ortodônticos ........................................................... 26

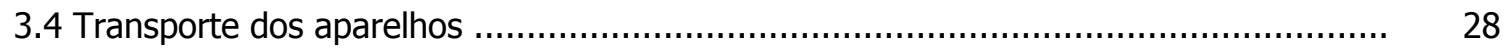

3.5 Avaliação da Formação de Biofilme in situ - Cultura Microbiana ............................... 30

3.6 Avaliação da Formação de Biofilme in situ - Microscopia Eletrônica de Varredura ........ 35

3.7 Avaliação da presença de Corrosão in situ - Estereomicroscopia Ótica, Microscopia Eletrônica de Varredura (MEV) e Espectrometria de Energia Dispersiva (EDS)............ $\quad 37$

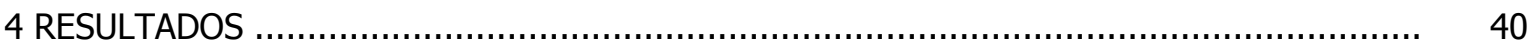

4.1 Da avaliação da formação de biofilme in situ - Cultura Microbiana ......................... 41

4.2 Da avaliação da formação de biofilme in situ - Microscopia Eletrônica de Varredura... 52

4.3 Da avaliação da presença de corrosão in situ - Estereomicroscopia Ótica, Microscopia Eletrônica de Varredura (MEV) e Espectrometria de Energia Dispersiva (EDS).......... 56

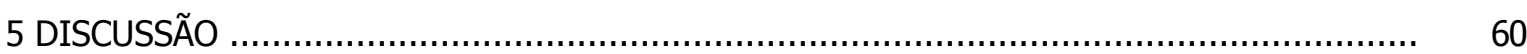

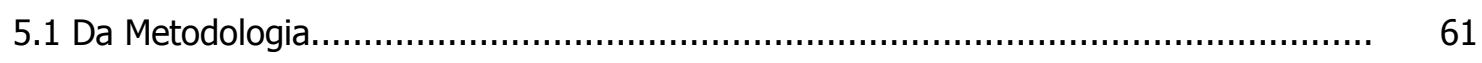

5.2 Dos Resultados da formação de biofilme in situ - Cultura Microbiana e MEV.............. 63

5.3 Dos Resultados da presença de corrosão in situ -Estereomicroscopia Ótica, Microscopia Eletrônica de Varredura (MEV) e Espectrometria de Energia Dispersiva

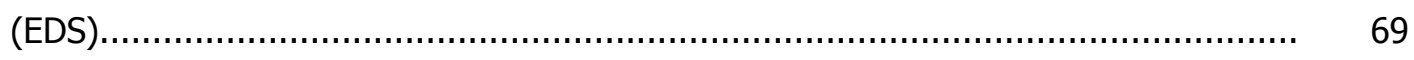

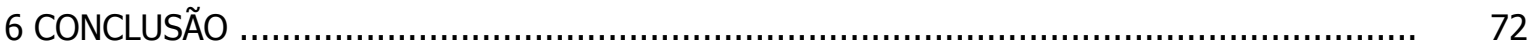

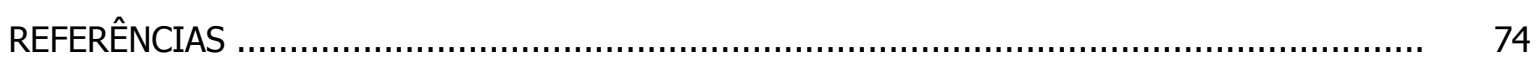

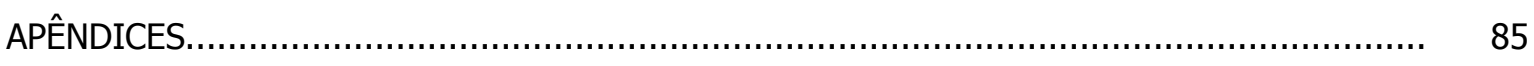

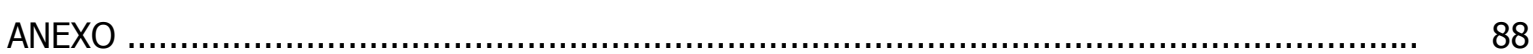




\section{INTRODUCÃO}




\section{InTRODUÇão}

O meio ambiente bucal oferece condições ideais para a colonização das partes anatômicas que o compõem por uma microbiota bastante complexa, que coexiste em homeostase com o hospedeiro (Fejerskov e Kidd, 2005). No entanto, quando ocorrem modificações no ambiente bucal, a microbiota também se altera, resultando em desequilíbrio, com possibilidade do desenvolvimento de doenças (Marsh, 2006).

O tratamento ortodôntico, particularmente por meio do uso de aparelhos fixos, ocasiona alterações específicas no meio bucal (Anhoury et al., 2002), incluindo redução do $\mathrm{pH}$, aumento no acúmulo de biofilme dental (Naranjo et al., 2006) e elevação dos níveis salivares de microrganismos (Rosenbloom e Tinanoff, 1991; Mattingly et al., 1983; Leung et al., 2006).

Tendo em vista que os aparelhos ortodônticos são compostos por uma variedade de materiais sólidos e elásticos (Stinberg e Eyal, 2004), após sua instalação na cavidade bucal proteínas salivares específicas irão adsorver nas diferentes superfícies dos mesmos (Ahn et al., 2002; Stinberg e Eyal, 2004), condicionando-as e desempenhando um importante papel na adesão bacteriana (Ahn et al., 2002). Além disso, as superfícies irregulares dos brackets, bandas, fios e outros acessórios funcionam como áreas de retenção de biofilme bacteriano (Rosenbloon e Tinanoff, 1991; Ahn et al., 2006; Leung et al., 2006), dificultam a higienização (Olympio et al., 2003) e limitam a ocorrência da auto-limpeza mecânica efetuada pela saliva e pela movimentação da musculatura (Rosenbloon e Tinanoff, 1991).

Esses fatores favorecem a queda do $\mathrm{pH}$ do biofilme dentário na presença de carboidratos fermentáveis, acelerando o acúmulo e a maturação do biofilme cariogênico, composto fundamentalmente por estreptococos do grupo mutans, os quais são microrganismos acidúridos e acidogênicos (Mizrahi, 1982; Gorelick et al., 1982; Ogaard et al., 1988; Mitchell, 1992), considerados os agentes etiológicos primários da cárie dental (Loesche, 1986; Mc Neill e Hamilton, 2003; Berkowitz, 2003; Ahn et al., 2007).

A produção de ácidos orgânicos ocasiona a desmineralização do esmalte, com a formação de manchas brancas opacas visíveis, que são a primeira evidência clínica da presença de lesões de cárie ao redor dos acessórios ortodônticos fixos (Anhoury et al., 2002; Chin et al., 2006; Sudjalim et al., 2007), quando programas preventivos individualizados não são implementados (Zachrisson, 1977). A despeito dos avanços nos materiais e técnicas 
empregados na Ortodontia nos últimos anos, cerca de 50 a $70 \%$ dos pacientes exibem manchas brancas ativas clinicamente visíveis (Ogaard et al., 2001; Gorelick et al., 1982; Ärtun e Brobakken, 1986), durante o tratamento ortodôntico que dura, aproximadamente, 2 anos (Basdra et al., 1996).

A instalação de aparelhos ortodônticos gera, também, um ambiente favorável para o acúmulo de microrganismos e resíduos alimentares, o que pode exacerbar alterações periodontais pré-existentes (Anhoury et al., 2002; Rosa et al., 2005; Naranjo et al., 2006).

Paralelamente, além da elevação dos níveis de microrganismos cariogênicos na saliva e no biofilme dental, vários autores têm se preocupado em avaliar a contaminação microbiana de componentes específicos dos aparelhos ortodônticos removíveis e fixos, assim como seu impacto sobre a microbiota da cavidade bucal. Empregando as técnicas de cultura microbiana, reação da polimerase em cadeia - PCR e Checkeboard DNA DNA Hybridization estes estudos incluem brackets (Anhoury et al., 2002; Steinberg e Eyal, 2004; Brêtas et al. 2005; Ahn et al., 2005; Leung et al., 2006; Ahn et al., 2007), fios ortodônticos (Diedrich, 1989; Turkkahraman et al., 2005), placas de resina (Auschill et al., 2005; Lessa et al., 2007; Peixoto, 2007), bandas (Huser et al., 1990; Anhoury et al., 2002; Fulford et al., 2003), molas, elásticos intra-bucais (Steinberg e Eyal, 2004; Brêtas et al., 2005; Magno et al., 2007) e micro-implantes para ancoragem esquelética (Chin et al., 2007), além de adesivos ortodônticos (Badawi et al., 2003; Ahn et al., 2006; Chin et al., 2006).

No entanto, tendo em vista que os aparelhos ortodônticos podem ser considerados fatores de risco clínico à integridade do esmalte e dos tecidos periodontais também devido ao acúmulo de biofilme que ocorre sobre as suas superfícies (Lessa et al., 2007; Peixoto, 2007; Magno et al., 2007), justifica-se a necessidade da realização de estudos focados no controle do biofilme in situ.

Para a prevenção e controle da instalação desses processos, embora os métodos de higiene bucal nos pacientes portadores de aparelhos ortodônticos devam ser enfatizados (Naranjo et al., 2006), em crianças, jovens e idosos a destreza manual e o cuidado com a higiene bucal, na maior parte das vezes, são fatores que comprometem o controle mecânico do biofilme (Dills et al., 1988). Adicionalmente, segundo Diedrich (1989) a escovação é ineficaz na remoção de microrganismos das áreas retentivas dos aparelhos. Em função disso, vários autores preconizam o uso de agentes antimicrobianos, principalmente sob a forma de bochechos, como coadjuvantes no controle do biofilme dental (Fardal e Turnbull, 1986; Brightman et al., 1991; Beyth et al., 2003; Olympio et al.,2006). 
No entanto, a formação de biofilme in situ, propondo métodos para o seu controle tem sido avaliada em um pequeno número de estudos, limitados a brackets (Brêtas et al., 2005), placas de resina acrílica (Auschill et al., 2005; Lessa et al., 2007; Peixoto, 2007) e ligaduras (Magno et al., 2007). Nesses estudos, especial enfoque é dado à clorexidina, considerada o antimicrobiano "padrão ouro", quando comparada aos demais agentes disponíveis no comércio especializado (Mosrefi, 2002). No entanto, não há estudos publicados avaliando a formação de biofilme bacteriano in situ na superfície de outras partes de aparelhos ortodônticos fixos.

Os aparelhos disjuntores de Haas são confeccionados com fios de aço, bandas, pontos de solda, acrílico e parafuso expansor, que são possíveis locais para adesão e proliferação microbiana, permanecendo cimentados na cavidade bucal por vários meses, em íntima proximidade com os tecidos moles e mineralizados da cavidade bucal. Assim, resultados de estudos avaliando a contaminação microbiana e métodos para o controle do biofilme nessas regiões apresentam grande aplicabilidade clínica.

Deve-se salientar, também, que o ambiente bucal é particularmente ideal para biodegradação de metais, devido às suas propriedades químicas, térmicas, microbiológicas e enzimáticas (Kedici, 1998). Segundo Bergman (1986), os metais utilizados em aparelhos ortodônticos, quando em contato com a saliva e alimentos (ácidos ou básicos), em diferentes temperaturas, podem sofrer corrosão eletroquímica no meio bucal. A corrosão de aparelhos ortodônticos pode apresentar implicações clínicas desfavoráveis, variando desde a perda de dimensão, que resulta na aplicação de forças menores sendo aplicadas aos dentes, até uma possível fratura do aparelho por corrosão sob tensão (Bergman, 1986). Além disso, no processo corrosivo, os íons metálicos liberados podem entrar em contato com células ou serem distribuídos pelo organismo. Os produtos tóxicos gerados pela corrosão do aparelho e sua absorção pelos tecidos é indesejável (Geis-Gerstorfer, 1994; Eliades et al., 2004; Siargos et al., 2007).

Em Odontologia, manifestações de corrosão podem exibir efeitos biológicos, funcionais e estéticos, sendo os efeitos biológicos os de maior significância (Geis-Gerstorfer, 1994; Eliades et al., 2001; Hwang et al., 2001; Kao et al., 2007). Quando os íons metálicos liberados nesse processo não são biocompatíveis, o organismo pode ser agredido pela toxicidade dos mesmos ou pelo risco de sensibilização (Kim et al., 1999; Huang et al., 2005; Iijima et al., 2006).

Vários estudos têm avaliado in vitro a corrosão em aparelhos ortodônticos, por meio da liberação de íons, incluindo basicamente níquel e cromo (Barret et al., 1993; 
Ferreira, 2005; Iijima et al., 2006) ou in vivo, usando indiretamente saliva, soro ou biofilme (Kerosuo et al., 1997; Agaoglu et al., 2001; Fors e Persson, 2006).

Tendo em vista que os aparelhos ortodônticos fixos podem atuar como nichos de retenção de microrganismos e estarem sujeitos ao processo corrosivo, estudos in situ avaliando a corrosão, assim como a contaminação bacteriana, propondo métodos eficazes para sua desinfecção do ponto de vista clínico, tornam-se necessários. 


\section{PROPOSICÃO}




\section{Proposição}

Este estudo teve como objetivo avaliar, in situ, em aparelhos disjuntores de Haas:

- A contaminação por estreptococos do grupo mutans, sob a forma de colônias/biofilmes, nas diferentes superfícies (acrílico, fios de aço, bandas e parafusos expansores), com e sem o uso de bochechos com gluconato de clorexidina a 0,12\%, por meio de Cultura Microbiana e Microscopia Eletrônica de Varredura (MEV); e

- A corrosão na área da união entre o fio, a solda de prata e a banda dos aparelhos, por meio de Estereomicroscopia Ótica, MEV e análise em Espectrometria de Energia Dispersiva (EDS). 


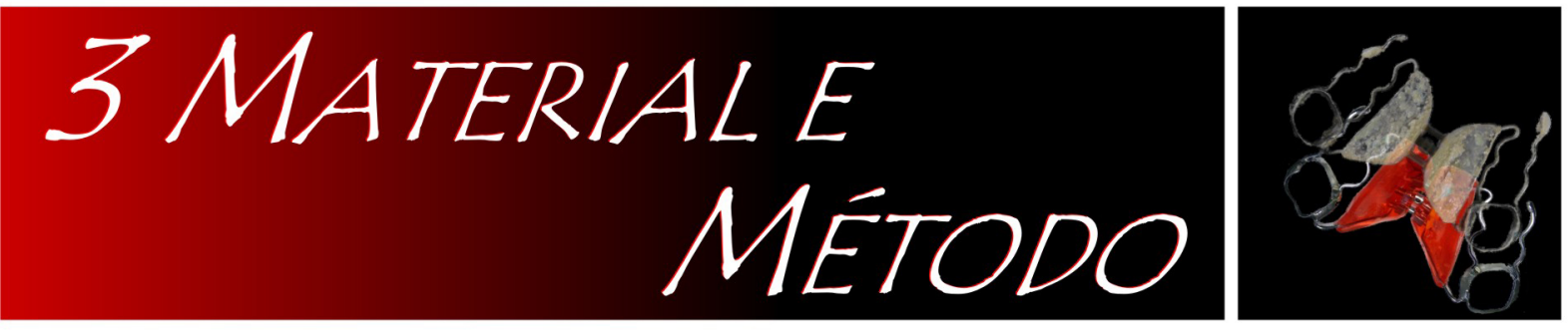




\section{Material e Método}

O presente estudo foi submetido à apreciação pelo Comitê de Ética em Pesquisa envolvendo Seres Humanos da Faculdade de Odontologia de Ribeirão Preto da Universidade de São Paulo - FORP/USP (Processo de $n^{\circ}$ 2006.1.391.58.9), tendo sido aprovado (Anexo A).

\subsection{Seleção da amostra}

Foram selecionados 34 pacientes (14 do gênero masculino e 20 do gênero feminino) de 7 a 12 anos de idade (média de 9 anos e 7 meses), que compareceram à clínica de Ortodontia Preventiva da FORP/USP, sem distinção de raça que, após anamnese e exame clínico apresentaram boa saúde geral e necessidade de correção com aparelho disjuntor de Haas por problemas transversais da maxila (mordida cruzada posterior). Os pacientes que fizeram uso de antibióticos e/ou bochechos com soluções antimicrobianas no período de 3 meses previamente ao início do estudo foram excluídos.

Os responsáveis pelos pacientes foram informados a respeito da pesquisa e assinaram um termo de consentimento livre e esclarecido, confirmando a participação de seus filhos no estudo (Apêndice $A$ ).

\subsection{Colheita e Processamento de amostras de saliva}

A fim de determinar se os 34 pacientes apresentavam estreptococos do grupo mutans, foram colhidos aproximadamente $2,0 \mathrm{~mL}$ de saliva em tubos de ensaio contendo pérolas de vidro. As amostras, após homogeneização em aparelho Mixtron-Toptronix (São Paulo - SP), foram submetidas à diluição decimal em série até $10^{-4}$, em solução salina tamponada fosfatada (PBS), pH 7,0. Alíquotas de 0,05mL da saliva pura e após diluição foram depositadas em placas de Petri contendo o meio de cultura $\mathrm{SB}_{20}$ modificado (Azevedo, 1988; Torres et al., 1993), seletivo para estreptococos do grupo mutans, e semeadas com auxílio de bastão de vidro angulado. Após semeadura, as placas foram incubadas em microaerofilia, pela técnica da chama de vela, durante 72 horas, a $37^{\circ} \mathrm{C}$.

Decorrido esse período, foi realizada a contagem do número de unidades formadoras de colônias (ufc), por $\mathrm{mL}$ de saliva, com auxílio de microscópio estereoscópico 
(Nikon - Japan). Colônias características do grupo mutans foram transferidas para tubos contendo o meio tioglicolato (Fluid thioglycollate medium w/o glucose or indicator - Difco), incubados a $37^{\circ} \mathrm{C}$ por 24 horas, para biotipagem. Foram efetuadas as seguintes provas bioquímicas, de acordo com Shklair e Keene (1974): fermentação do manitol, sorbitol, rafinose e melibiose, resistência à bacitracina, hidrólise da esculina e produção de peróxido de hidrogênio (Whittenbury, 1964), segundo modificações propostas por Ito et al. (1993), e hidrólise da arginina.

De acordo com os resultados obtidos observou-se que os 34 pacientes (100\%) apresentaram estreptococos do grupo mutans na saliva.

Em seguida, utilizando uma tabela de números randômicos, os pacientes foram aleatoriamente divididos em dois grupos de 17 indivíduos cada (Grupos I e II).

\subsection{Confecção dos aparelhos ortodônticos (Figura 1)}

Os pacientes foram moldados com alginato Jeltrate (Dentsply) utilizando-se moldeira ortodôntica. Após a desinfecção da moldagem com spray de hipoclorito de sódio a $1 \%$, por 10 minutos, os moldes foram vazados com gesso pedra branco tipo a especial (Mossoró), obtendo-se os modelos de gesso.

Foram confeccionados aparelhos do tipo Haas, com fios de aço inoxidável de 0,9mm (Dentaurum), soldados (solda de prata - Dental Morelli - Sorocaba - SP - Brasil) a bandas metálicas (Dental Morelli - Sorocaba - SP - Brasil) nos dentes de ancoragem posterior (molares permanentes). Como elemento ativo foi utilizado um parafuso expansor nacional de $11 \mathrm{~mm}$ (Dental Morelli - Sorocaba - SP - Brasil) localizado na região da sutura palatina mediana. Com o parafuso, bandas e fios soldados e em posição, o modelo de gesso foi isolado com Cel-Lac (S.S. White Artigos Odontológicos) para a aplicação da resina acrílica autopolimerizável JET (Artigos Odontológicos Clássico Ltda.), seguindo a proporção monômero/polímero recomendada pelo fabricante. O modelo foi, então, colocado em panela sob pressão (VH Soft Line - Polimerizador para acrílico) durante 5 minutos, para evitar a formação de bolhas.

Após a polimerização do acrílico, realizou-se o recorte e acabamento do aparelho, utilizando fresa de tungstênio em motor com peça de mão para baixa rotação. Para acabamento e regularização da superfície, foram utilizadas lixas para madeira $n^{\circ} 180$ e lixas d'água $n^{\circ} 400$ e 600, montadas em mandris e motor de baixa rotação com peça de mão. O polimento do aparelho foi realizado inicialmente com escova de pêlos em forma de 
roda, montada em torno para polimento, utilizando-se baixa velocidade e pasta de pedrapomes e água, seguida de roda de pano. O acabamento final foi realizado em polidora química (PQ 9000 - Termotron). A fixação das bandas do aparelho na cavidade bucal foi realizada com cimento fosfato de zinco (Cimento LS - Vigodent S/A Indústria e Comércio Rio de Janeiro - RJ - Brasil) e, em seguida, foi efetuada a fixação do fio ortodôntico nos dentes de ancoragem anterior (caninos ou molares decíduos) com resina fotopolimerizável (TPH - 3M).

A disjunção foi efetuada de acordo com a recomendação de Zimring e Isaacson (1969) e Thomazinho et al. (2005), ou seja, 2 voltas por dia nos primeiros 4 a 5 dias e 1 volta por dia no restante do tratamento. Conseguida a correção, que durou em média 20 dias, o aparelho foi mantido por mais 3 meses na cavidade bucal, como período de contenção do caso.

Durante todo o período de permanência dos aparelhos na cavidade bucal, no Grupo I (controle; $\mathrm{n}=17$ ) os pacientes foram orientados a utilizar dentifrício fluoretado para escovação diária e não empregar bochechos com soluções antimicrobianas.

Por outro lado, no Grupo II (experimental; $n=17$ ) os pacientes foram orientados a realizar, além da escovação diária com o uso de dentifrício fluoretado, bochechos com solução antimicrobiana. Com essa finalidade, cada paciente desse grupo recebeu a solução de gluconato de Clorexidina a 0,12\% (Periogard $^{\circledR}$ - Colgate Palmolive Kolynos do Brasil Ltda.), previamente acondicionada em frasco de plástico individual $(120 \mathrm{~mL})$, e copos para a realização de bochechos com $10 \mathrm{~mL}$ da solução, durante um minuto, duas vezes por semana (terças e sextas-feiras). Às terças-feiras o paciente comparecia à Faculdade, sendo o bochecho realizado sob supervisão do pesquisador, enquanto que às sextas-feiras o paciente realizava o bochecho em seu domicílio, sob a supervisão de um responsável (geralmente a mãe).

De acordo com o fabricante, o Periogard ${ }^{\circledR}$ apresenta a seguinte composição: gluconato de clorexidina a 0,12\%, água, glicerina, etanol, polisorbato 20, composição aromática sabor menta, sacarinato de sódio e corante FD \& Blue $n^{\circ} 1$.

Decorrido o período de correção e contenção, os parelhos foram removidos da cavidade bucal com brocas de baixa rotação multi-laminadas esterilizadas (Bush), para desgaste da resina aderida aos dentes de ancoragem, e com alicate saca-banda número 345 (Starlet - São Paulo - SP - Brasil) esterilizado, para remoção das bandas metálicas.

Após a remoção dos aparelhos da cavidade bucal dos pacientes dos Grupos I e II foram seccionadas, aleatoriamente, partes dos aparelhos incluindo a região de fio/banda/solda, de apenas um dos lados (direito ou esquerdo). O corte foi realizado com 
alicate esterilizado (Orthopli 021 - Dentaurum - Alemanha), em zona asséptica obtida com o uso de duas lamparinas acesas, estando os aparelhos seguros com auxílio de uma pinça clínica para algodão número 317 (Duflex - Santo André - SP - Brasil) esterilizada. As partes do aparelho constituídas de banda com fio soldado foram acondicionadas em dessecador completo de 300mm (Vidrolabor) contendo sílica gel como indicador de umidade, para posterior análise do processo corrosivo.

\subsection{Transporte dos aparelhos}

Após esse procedimento, os aparelhos foram individualmente acondicionados em coletores universais esterilizados de $100 \mathrm{~mL}$ (Pleion Indústria e Comércio de Plásticos Ltda.) e transportados ao laboratório de Microbiologia do Departamento de Análises Clínicas, Toxicológicas e Bromatológicas da Faculdade de Ciências Farmacêuticas de Ribeirão Preto Universidade de São Paulo, para processamento microbiológico. 
Figura 1 - CONFECÇÃO DOS APARELHOS DISJUNTORES DE HAAS

A - Fio em contato com a banda fixado com gesso pedra.

B - Aplicação da pasta para solda de prata.

C - Soldagem do fio à banda.

D - Posicionamento do parafuso expansor de $11 \mathrm{~mm}$.

E- Aplicação do Cel-Lac no modelo de gesso.

F - Manipulação da resina acrílica autopolimerizável.

G - Colocação da resina acrílica sob o parafuso.

H - Colocação da resina acrílica no modelo.

I - Aparelho colocado em panela sob pressão.

J - Recorte do aparelho utilizando fresa de tungstênio.

K - Polimento químico.

L - Aspecto final do aparelho. 

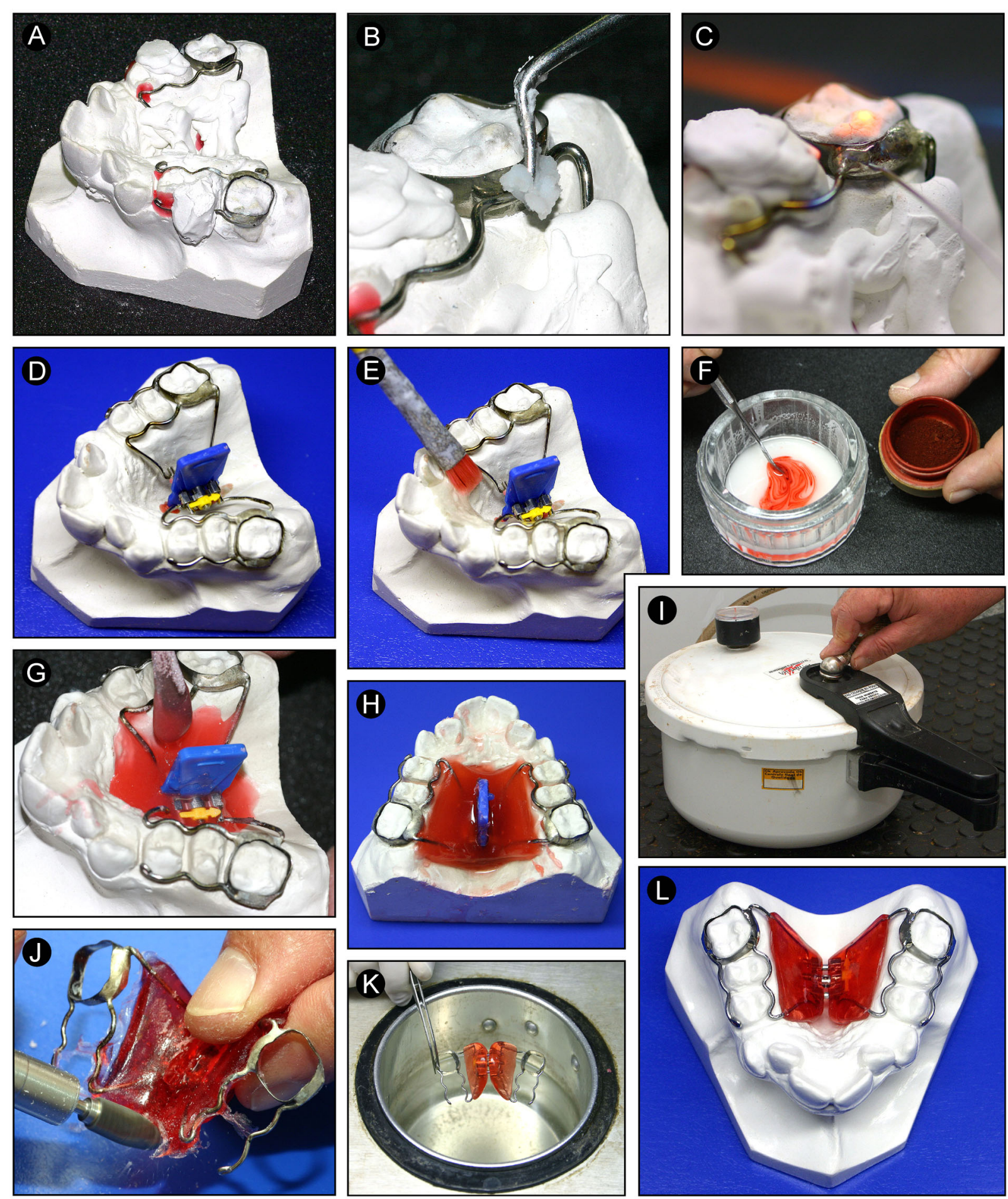


\subsection{Avaliação da Formação de Biofilme in situ - Cultura Microbiana}

\section{Preparo do meio de cultura CaSa B (Caldo Sacarose Bacitracina)}

O meio de cultura CaSa B, seletivo enriquecedor para estreptococos do grupo mutans, foi preparado como descrito por Jensen e Bratthall (1989), sem azul de tripan, como sugerido por Cesco et al., em 1995.

\section{Meio de cultura CaSA B - Composição:}

$\begin{array}{llc}\text { Casitone } & \text { (Difco) } & 15,0 \mathrm{~g} \\ \text { Extrato de Levedura } & \text { (Difco) } & 5,0 \mathrm{~g} \\ \text { L - cisteína } & \text { (Merck) } & 0,2 \mathrm{~g} \\ \text { Sulfito de sódio } & \text { (Merck) } & 0,1 \mathrm{~g} \\ \text { Acetato de sódio } & \text { (Reagen) } & 20,0 \mathrm{~g} \\ \text { Sacarose } & \text { (Açúcar Cristal) } & 200,0 \mathrm{~g} \\ \text { Água destilada q.s.p. } & & 1000,0 \mathrm{~mL}\end{array}$

Por meio da utilização de uma balança elétrica (Marte), os componentes foram colocados em balão de Erlenmeyer, onde foram adicionados 1000,0mL de água destilada. Após homogeneização, o meio foi esterilizado em autoclave a $120^{\circ} \mathrm{C}$, por 20 minutos. Decorrido este período, a autoclave foi aberta cuidadosamente para resfriamento rápido, evitando a caramelização do açúcar. O meio preparado foi, então, armazenado à temperatura ambiente. No momento do uso, adicionou-se $1 \%$ da solução de bacitracina $(0,0033 \mathrm{~g}$ de Bacitracina/Sigma e 10,0 mL de água destilada esterilizada) ao meio sendo, a seguir, realizada a homogeneização do mesmo. O meio de cultura CaSa B preparado foi então colocado em coletores universais esterilizados de $100 \mathrm{~mL}$ (Pleion Indústria e Comércio de Plásticos Ltda.) de forma que, quando da colocação do aparelho ortodôntico nesse coletor, o mesmo ficasse completamente imerso no meio de cultura. O meio foi conservado em refrigerador, à temperatura de $4^{\circ} \mathrm{C}$, sendo utilizado no prazo máximo de 7 dias, uma vez que a bacitracina perde a sua atividade antimicrobiana após esse período.

O meio de cultura seletivo enriquecedor CaSa B foi empregado para avaliar a formação de biofilme por estreptococos do grupo mutans, nas diferentes superfícies dos disjuntores de Haas. 


\section{Preparo do meio de cultura $\mathbf{S B}_{20}$ (Ágar Sacarose Bacitracina) modificado}

Este meio de cultura seletivo, preparado como preconizado por Azevedo (1988) e Torres et al. (1993), foi empregado para confirmar se os microrganismos que se desenvolveram sobre as superfícies dos aparelhos, sob a forma de colônias/biofilmes, realmente eram pertencentes ao grupo mutans.

\section{Meio de Cultura $\mathrm{SB}_{20}$ modificado - Composição:}

$\begin{array}{llc}\text { Casitone } & \text { (Difco) } & 15,0 \mathrm{~g} \\ \text { Extrato de Levedura } & \text { (Difco) } & 5,0 \mathrm{~g} \\ \text { L- cisteína } & \text { (Merck) } & 0,2 \mathrm{~g} \\ \text { Sulfito de sódio } & \text { (Merck) } & 0,1 \mathrm{~g} \\ \text { Acetato de sódio } & \text { (Reagen) } & 20,0 \mathrm{~g} \\ \text { Sacarose } & \text { (Açúcar Cristal) } & 200,0 \mathrm{~g} \\ \text { Ágar - Ágar } & \text { (Difco) } & 15,0 \mathrm{~g} \\ \text { Água destilada q.s.p. } & & 1000,0 \mathrm{~mL}\end{array}$

Por meio da utilização de uma balança elétrica (Marte), com exceção do ágar e da sacarose, os componentes foram pesados e colocados em um cálice com 1000,0mL de água destilada, sendo dissolvidos com auxílio de bastão de vidro. Ao ágar e à sacarose, pesados e colocados em balão de Erlenmeyer, foi adicionada a solução obtida, lavando-se as paredes do balão. A seguir, os balões foram tamponados com algodão, identificados e esterilizados a $120^{\circ} \mathrm{C}$ por 20 minutos. Após o resfriamento até cerca de $50^{\circ} \mathrm{C}, 1,0 \%$ da solução de bacitracina (Sigma) foi adicionada e homogeneizada $(0,0033 \mathrm{~g}$ a $10,0 \mathrm{~mL}$ de água). O meio assim obtido foi vertido assepticamente em placas de Petri de $20 \times 100 \mathrm{~mm}$ esterilizadas, em volumes de 20,0mL. Após a solidificação as placas foram mantidas em refrigerador a $4^{\circ} \mathrm{C}$, sendo utilizadas no período máximo de 7 dias.

\section{Semeadura e Incubação}

Após serem imersos nos coletores universais contendo o meio de cultura CaSa $\mathrm{B}$, os aparelhos foram incubados por 3 a 4 dias, a $37^{\circ} \mathrm{C}$. Decorrido o tempo de incubação, foram submetidos à agitação manual no próprio meio de cultura e retirados, cuidadosamente, dos coletores. 


\section{Contagem das Colônias/Biofilmes de Estreptococos do Grupo Mutans}

A seguir, os aparelhos foram analisados quanto à presença ou não de desenvolvimento de biofilme, com o auxílio de microscópio estereoscópico (Nikon - Japão), sob luz refletida, sendo efetuada a contagem das colônias/biofilmes de estreptococos do grupo mutans.

A contagem foi realizada nas superfícies livres (voltadas para a cavidade bucal), onde o agente antimicrobiano facilmente teria acesso, e nas superfícies não-livres (em contato direto com a mucosa palatina e sulco gengival), onde o acesso do agente antimicrobiano, supostamente, seria fisicamente dificultado. Assim, para análise os aparelhos foram divididos nas seguintes áreas:

- Acrílico: superfície livre (voltada para a cavidade bucal) e não-livre (voltada para o palato);

- Banda: superfície livre (porção extra-sulcular) e não-livre (porção intrasulcular); e

- Parafuso: superfície livre (voltada para a cavidade bucal) e não-livre (voltada para o palato).

Nos fios ortodônticos (fio vestibular e fio palatino), que apresentam secção transversal circular, a contagem foi efetuada em toda a superfície metálica.

Como sugerido por Nelson-Filho et al. (2006) e por Lessa et al. (2007), o número de colônias/biofilmes foi expresso tendo como base os seguintes parâmetros:

- $\quad 0$ : ausência de colônias/biofilmes;

- 1 a 100: quando foi possível efetuar a contagem exata do número de colônias/biofilmes presentes;

- +100: quando as colônias não se confluíram, possibilitando a contagem de valores superiores a 100 colônias/biofilmes; e

- Incontável: quando o desenvolvimento bacteriano foi tão intenso, inclusive com colônias confluentes, impossibilitando a contagem exata do número de colônias/biofimes de estreptococos do grupo mutans.

Esses dados foram anotados em fichas especialmente desenvolvidas para esse estudo (Apêndice B).

A figura 2 apresenta o fluxograma da metodologia empregada no estudo por meio da cultura microbiana. 


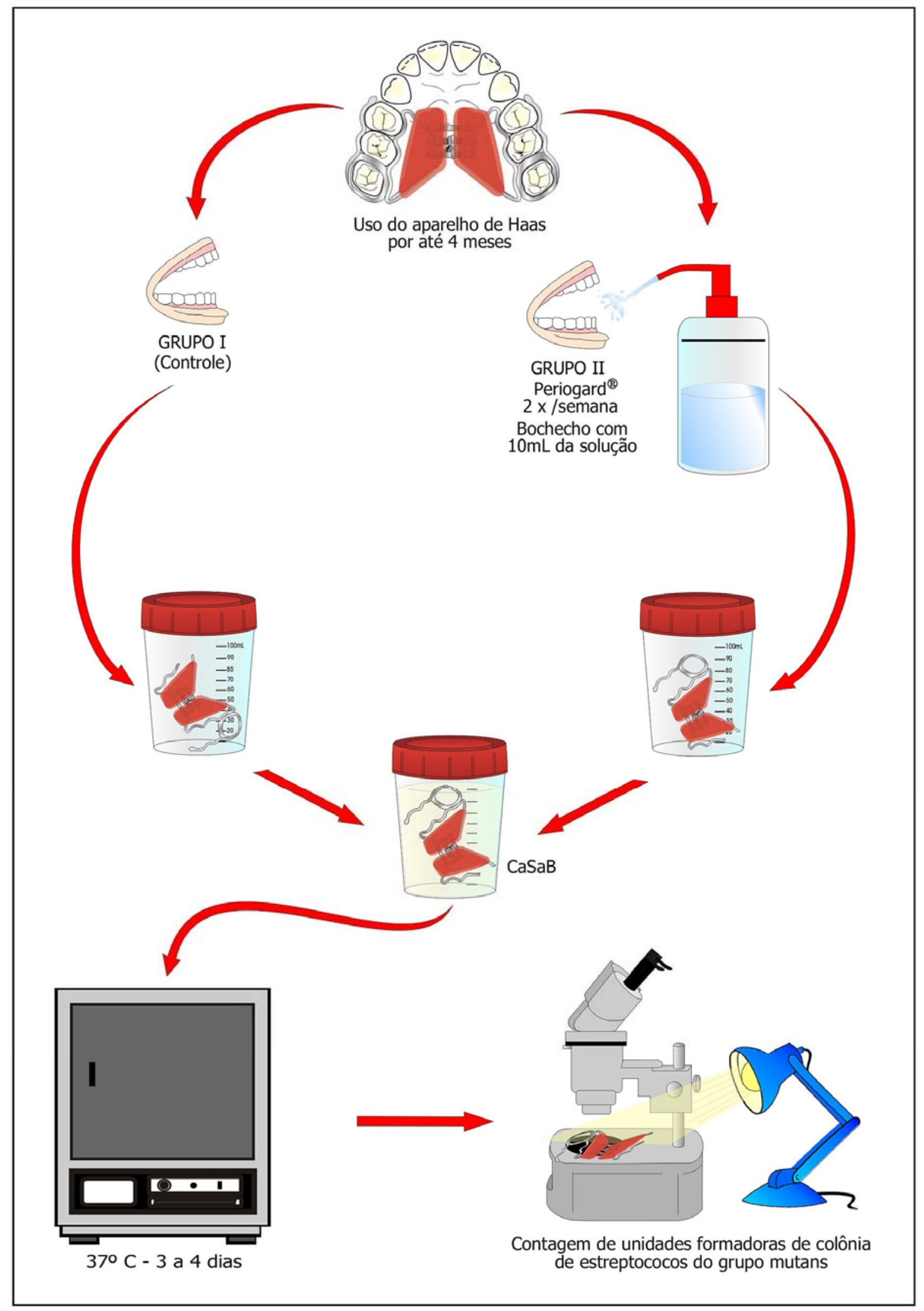

Figura 2 - Fluxograma do estudo clínico randomizado. 


\section{Confirmação da Identidade Microbiana}

A confirmação de que os microrganismos presentes nas diferentes áreas dos aparelhos, contados sob a forma de colônias/biofilmes, realmente eram pertencentes ao grupo mutans, foi realizada transferindo-se algumas colônias/biofilmes com aspecto macroscópico característico do grupo mutans para tubos contendo pérolas de vidro e 2,0mL de Tampão Fosfato Sorensen (PBS), preparado segundo Sober e Harte (1968). Após agitação em aparelho Mixtron-Toptronix (São Paulo - SP), em velocidade 4, por 2 minutos, foi efetuada a semeadura de alíquotas da suspensão resultante no meio de cultura $\mathrm{SB}_{20}$ modificado, seletivo para estreptococos do grupo mutans. Decorridas 72 horas de incubação em microaerofilia, a $37^{\circ} \mathrm{C}$, foi verificado o desenvolvimento de unidades formadoras de colônia, efetuando-se a identificação bioquímica de acordo com Shklair e Keene (1974) e Whittenbury (1964), com modificações propostas por Ito et al. (1993).

\section{Análise Estatística}

Para a análise estatística, os resultados obtidos pós-cultura microbiana da variável colônias/biofilmes foram confrontados por meio do programa estatístico SAS (Statistical Analyses System).

Para a realização da análise estatística com relação à presença ou ausência de colônias/biofilmes, as contagens foram convertidas em escores tendo como base os seguintes parâmetros:

- Escore 0: aparelhos com ausência de formação de colônias/biofilmes;

- Escore 1: de 1 a 100 colônias/biofilmes;

- Escore 2: mais de 100 colônias/biofilmes, em quantidades contáveis.

- Escore 3: nível incontável de colônias/biofimes.

O teste estatístico não-paramétrico de Mann-Whitney foi aplicado para verificação de possíveis diferenças entre os grupos, com relação à formação do biofilme microbiano sobre as superfícies das diferentes áreas (parafuso, resina acrílica, bandas, fio vestibular e fio palatino), como também para verificar se havia diferença entre a formação de colônias/biofilmes sobre as superfícies livres (voltadas para cavidade bucal) e as superfícies não-livres (em contato direto com mucosa palatina e sulco gengival). 0 nível de significância adotado foi de $5 \%$. 


\subsection{Avaliação da Formação de Biofilme in situ - Microscopia Eletrônica de Varredura}

Após a realização do processamento microbiológico e contagem das colônias/biofilmes, 6 aparelhos representativos do desenvolvimento microbiano observado em cada Grupo (I e II), totalizando 12 aparelhos, foram seccionados com alicate obtendo-se partes isoladas de resina acrílica, bandas, parafusos e fios. Essas partes dos aparelhos foram colocadas em frascos contendo solução de glutaraldeído a $3 \%$ e cacodilato de sódio $0,1 \mathrm{M}$. Em seguida, os frascos foram transportados ao Laboratório de Microscopia da Faculdade de Ciências Agrárias e Veterinárias de Jaboticabal (Universidade Estadual Paulista), para processamento e análise em microscopia eletrônica de varredura (MEV).

Decorridas 48 horas de permanência no glutaraldeído, as peças foram lavadas com água destilada e colocadas em frascos contendo álcool em diferentes concentrações $(30,50,70,80,90$ e 100\%), seqüencialmente, por um período de 10 minutos em cada frasco.

As peças foram então submetidas à secagem $\mathrm{com} \mathrm{CO}_{2}$, no ponto crítico, em aparelho EMS 850, e montadas em "stubs" metálicos, com fita adesiva e cola de prata condutora. A seguir, foram submetidas ao processo de metalização em ouro sob vácuo, em aparelho Denton Vacuum Desk II, durante 125 segundos. A análise foi efetuada em microscópio eletrônico (EVO $50^{\circledR}$ - Carl Zeiss SMT) a 20.00kV. Para evidenciar a presença ou ausência de formação de biofilme em MEV, foram efetuadas eletromicrografias das peças, com aumentos variando de 15 a 25000 vezes.

A figura 3 representa o fluxograma da metodologia empregada para o estudo em MEV. 


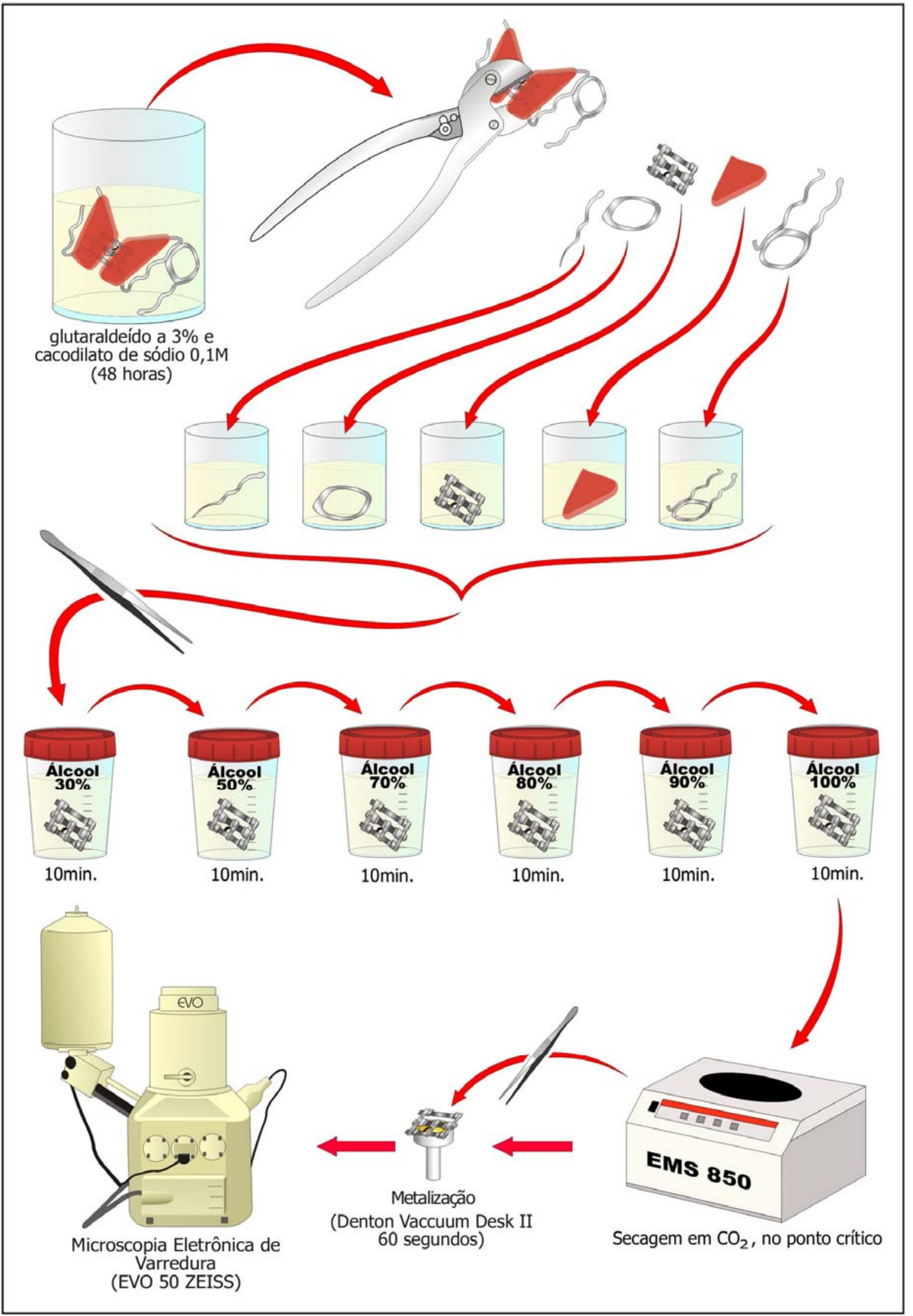

Figura 3 - Fluxograma da metodologia empregada no processamento para microscopia eletrônica de varredura. 


\subsection{Avaliação da presença de Corrosão in situ - Estereomicroscopia Ótica, Microscopia Eletrônica de Varredura (MEV) e Espectrometria de Energia Dispersiva (EDS)}

A análise da presença de corrosão in situ foi efetuada nas partes previamente seccionadas dos aparelhos, na área da união entre o fio, a solda de prata e a banda. Como já salientado, este segmento foi armazenado em um dessecador completo de $300 \mathrm{~mm}$ (Vidrolabor) contendo sílica gel, impedindo o contato com a umidade, até o momento da análise.

Todas as partes destinadas à avaliação do processo corrosivo foram observadas em estereomicroscópio (Laica L2) acoplado a uma máquina fotográfica digital (Sony Cyber Shot 3.3 megapixels DSC-575) com aumento de 40x, para obtenção de fotografias das regiões de contato entre solda-banda, solda-fio e fio/solda/banda, de todos os espécimes, de ambos os grupos, como sugerido por Wichelhaus et al. (2004) e Ferreira (2005).

As fotografias obtidas foram analisadas com relação à presença de áreas com alteração de coloração, com formação de uma superfície oxidada semelhante à ferrugem, sugerindo a presença de corrosão. Esta avaliação qualitativa, empregada em vários estudos (Kim et al., 1999; Eliades et al., 2000; O'Hoy et al., 2003; Wichelhaus et al., 2004; Ferreira, 2005), nos permitiu delimitar as áreas a serem observadas em Microscopia Eletrônica de Varredura (MEV) e em Espectrometria de Energia Dispersiva (EDS).

A presença (+) ou ausência (-) de alteração de coloração sugestiva de corrosão in situ pela Estereomicroscopia Ótica, em ambos os grupos, foram comparadas empregando o Programa SAS (Statistical Analyses System), por meio do teste de Fisher, com nível de significância de $5 \%$.

Em seguida, os espécimes foram transportados ao laboratório de Microscopia da Faculdade de Filosofia, Ciências e Letras de Ribeirão Preto - Departamento de Química (Universidade de São Paulo), para processamento e avaliação em MEV e EDS. A análise foi efetuada em aparelho EVO $50^{\circledR}$ (Carl Zeiss SMT) a 20.00kV, acoplado ao dispositivo IXRF Systems, que permitiu analisar a área determinada com aumentos variando de 60 a 194 vezes em detectores QBSD, com uma profundidade de penetração do feixe de elétrons préestabelecida.

Essa análise foi efetuada para identificar os picos dos seguintes elementos químicos: Níquel (Ni), Ferro (Fe), Cromo (Cr), Oxigênio (O), Carbono (C) e Fósforo (P), na 
região delimitada nos aparelhos de ambos os grupos (I e II). Empregando o programa EDX/2004, foram obtidos gráficos dos picos da presença dos referidos elementos químicos.

A metodologia empregada para o estudo em Estereomicroscopia Ótica, MEV e EDS encontra-se ilustrada na figura 4. 


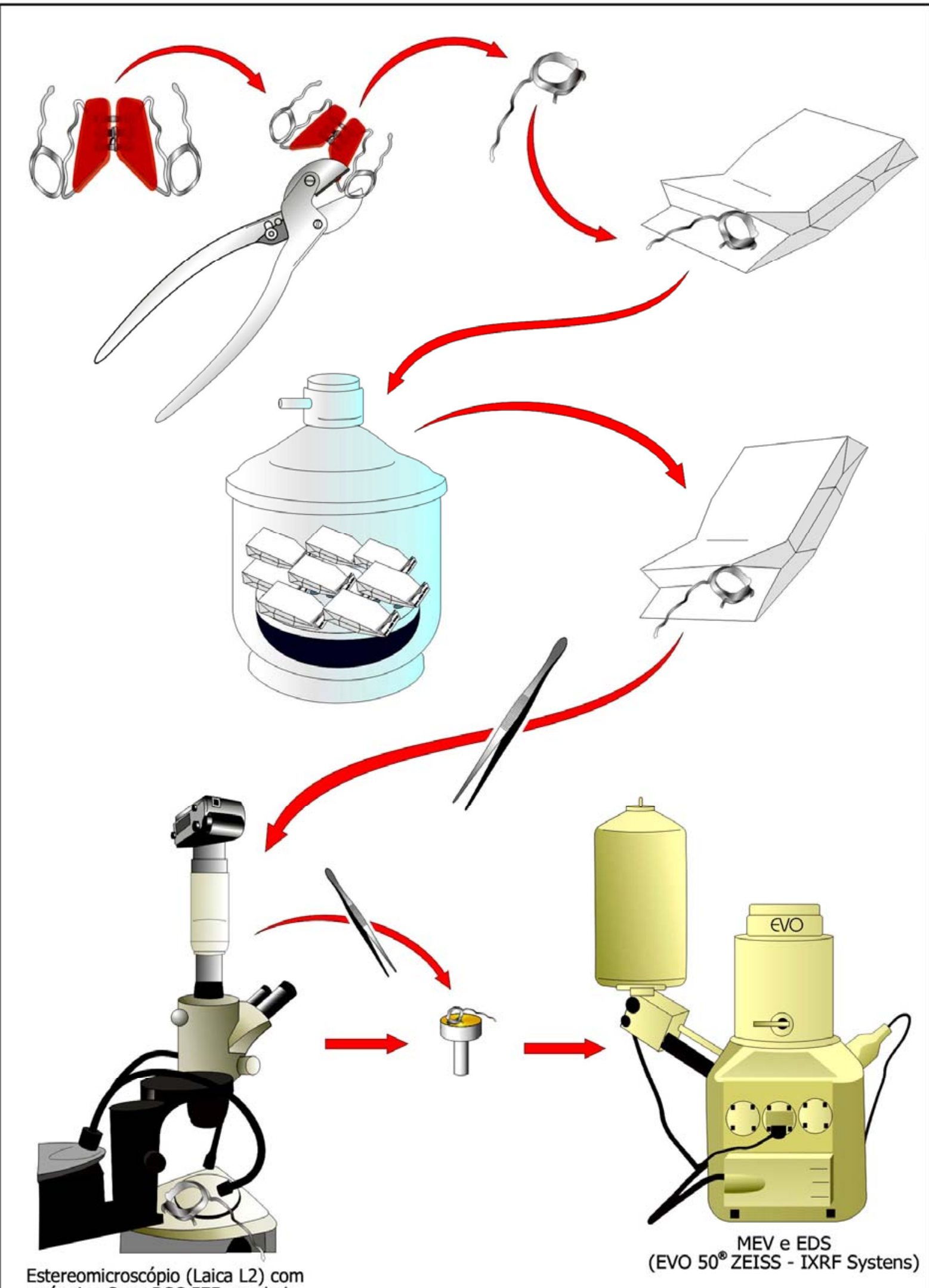
máquina Sony DSC-575 acoplada

Figura 4 - Fluxograma da metodologia empregada para o estudo em Estereomicrospia ótica, MEV e EDS. 


\section{RESULTADOS}




\section{Resultados}

\subsection{Da avaliação da formação de biofilme in situ - Cultura Microbiana}

Os 34 pacientes (100\%) participaram do estudo até a sua conclusão. O número de colônias/biofilmes de estreptococos do grupo mutans, em escores, observados na superfície dos fios ortodônticos e nas superfícies livres (voltadas para a cavidade bucal) e não-livres (em contato direto com a mucosa palatina e sulco gengival) do parafuso, acrílico e bandas dos Grupos I (controle) e II (uso de Periogard ${ }^{\circledR}$ ) estão apresentados nas tabelas 1, 2,3 e 4 .

No Grupo I, colônias/biofilmes de estreptococos do grupo mutans estavam presentes em todos (100\%) os aparelhos ortodônticos (Figuras 5A-G e 6A-H), com escore predominantemente 3. Em ambas as superfícies livres e não-livres da resina acrílica e da banda observou-se intensa contaminação microbiana (escore 3) em 100\% dos casos. Nas superfícies livres do parafuso observou-se escore 3 em 15 espécimes (88,2\% dos casos), enquanto que nas superfícies não-livres observou-se escore 3 em 14 espécimes (82,4\% dos casos). Nos fios palatino e vestibular observou-se escore 3 em $100 \%$ dos casos (Tabelas 1 e 2).

Nos espécimes do Grupo II, onde o Periogard ${ }^{\circledR}$ foi utilizado (Figura 7A-G), 0 nível de contaminação microbiana observado nas superfícies livres (onde 0 agente antimicrobiano teve acesso) foi muito menor que no Grupo I (controle) (Tabelas 3 e 4). 
Tabela 1 - Formação de biofilme in situ por estreptococos do grupo mutans, em escores, nas áreas do parafuso, do acrílico e da banda dos aparelhos disjuntores de Haas do Grupo I (controle).

\begin{tabular}{|c|c|c|c|c|}
\hline Espécime & Superfície & Parafuso & Resina & Banda \\
\hline \multirow{2}{*}{1} & Não-livre & 3 & 3 & 3 \\
\hline & Livre & 3 & 3 & 3 \\
\hline \multirow{2}{*}{2} & Não-livre & 3 & 3 & 3 \\
\hline & Livre & 3 & 3 & 3 \\
\hline \multirow{2}{*}{3} & Não-livre & 0 & 3 & 3 \\
\hline & Livre & 3 & 3 & 3 \\
\hline \multirow{2}{*}{4} & Não-livre & 3 & 3 & 3 \\
\hline & Livre & 3 & 3 & 3 \\
\hline \multirow{2}{*}{5} & Não-livre & 3 & 3 & 3 \\
\hline & Livre & 3 & 3 & 3 \\
\hline \multirow{2}{*}{6} & Não-livre & 3 & 3 & 3 \\
\hline & Livre & 3 & 3 & 3 \\
\hline \multirow{2}{*}{7} & Não-livre & 3 & 3 & 3 \\
\hline & Livre & 3 & 3 & 3 \\
\hline \multirow{2}{*}{8} & Não-livre & 3 & 3 & 3 \\
\hline & Livre & 3 & 3 & 3 \\
\hline \multirow{2}{*}{9} & Não-livre & 3 & 3 & 3 \\
\hline & Livre & 3 & 3 & 3 \\
\hline \multirow{2}{*}{10} & Não-livre & 3 & 3 & 3 \\
\hline & Livre & 3 & 3 & 3 \\
\hline \multirow{2}{*}{11} & Não-livre & 3 & 3 & 3 \\
\hline & Livre & 3 & 3 & 3 \\
\hline \multirow{2}{*}{12} & Não-livre & 0 & 3 & 3 \\
\hline & Livre & 3 & 3 & 3 \\
\hline \multirow{2}{*}{13} & Não-livre & 3 & 3 & 3 \\
\hline & Livre & 3 & 3 & 3 \\
\hline \multirow{2}{*}{14} & Não-livre & 3 & 3 & 3 \\
\hline & Livre & 1 & 3 & 3 \\
\hline \multirow{2}{*}{15} & Não-livre & 3 & 3 & 3 \\
\hline & Livre & 1 & 3 & 3 \\
\hline \multirow{2}{*}{16} & Não-livre & 0 & 3 & 3 \\
\hline & Livre & 3 & 3 & 3 \\
\hline \multirow{2}{*}{17} & Não-livre & 3 & 3 & 3 \\
\hline & Livre & 3 & 3 & 3 \\
\hline
\end{tabular}

Escores: 0 = ausência de biofilme; $1=1$ a 100 colônias/biofilmes; $2=+100$ colônias/biofilmes; 3 = incontável 
Tabela 2 - Formação de biofilme in situ por estreptococos do grupo mutans, em escores, nos fios (vestibular e palatino) dos aparelhos disjuntores de Haas do Grupo I (controle).

\begin{tabular}{|c|c|c|}
\hline Espécime & Fio vestibular & Fio palatino \\
\hline 1 & 3 & 3 \\
\hline 2 & 3 & 3 \\
\hline 3 & 3 & 3 \\
\hline 4 & 3 & 3 \\
\hline 5 & 3 & 3 \\
\hline 6 & 3 & 3 \\
\hline 7 & 3 & 3 \\
\hline 8 & 3 & 3 \\
\hline 9 & 3 & 3 \\
\hline 10 & 3 & 3 \\
\hline 11 & 3 & 3 \\
\hline 12 & 3 & 3 \\
\hline 13 & 3 & 3 \\
\hline 14 & 3 & 3 \\
\hline 15 & 3 & 3 \\
\hline 16 & 3 & 3 \\
\hline 17 & 3 & 3 \\
\hline
\end{tabular}

Escores: 0 = ausência de biofilme; $1=1$ a 100 colônias/biofilmes; $2=+100$ colônias/biofilmes; $3=$ incontável 
Tabela 3 - Formação de biofilme in situ por estreptococos do grupo mutans (escores) nas áreas do parafuso, do acrílico e da banda dos aparelhos disjuntores de Haas do Grupo II (uso de Periogard ${ }^{\circledR}$ ).

\begin{tabular}{|c|c|c|c|c|}
\hline Espécime & Superfície & Parafuso & Resina & Banda \\
\hline \multirow{2}{*}{1} & Não-livre & 0 & 3 & 3 \\
\hline & Livre & 3 & 1 & 1 \\
\hline \multirow{2}{*}{2} & Não-livre & 3 & 3 & 3 \\
\hline & Livre & 3 & 0 & 0 \\
\hline \multirow{2}{*}{3} & Não-livre & 3 & 3 & 3 \\
\hline & Livre & 3 & 1 & 1 \\
\hline \multirow{2}{*}{4} & Não-livre & 3 & 3 & 3 \\
\hline & Livre & 0 & 0 & 0 \\
\hline \multirow{2}{*}{5} & Não-livre & 3 & 3 & 3 \\
\hline & Livre & 3 & 0 & 0 \\
\hline \multirow{2}{*}{6} & Não-livre & 0 & 3 & 3 \\
\hline & Livre & 0 & 0 & 0 \\
\hline \multirow{2}{*}{7} & Não-livre & 3 & 3 & 3 \\
\hline & Livre & 0 & 0 & 0 \\
\hline \multirow{2}{*}{8} & Não-livre & 3 & 3 & 3 \\
\hline & Livre & 0 & 0 & 0 \\
\hline \multirow{2}{*}{9} & Não-livre & 3 & 3 & 3 \\
\hline & Livre & 0 & 0 & 0 \\
\hline \multirow{2}{*}{10} & Não-livre & 0 & 3 & 3 \\
\hline & Livre & 0 & 0 & 0 \\
\hline \multirow{2}{*}{11} & Não-livre & 3 & 3 & 3 \\
\hline & Livre & 0 & 0 & 0 \\
\hline \multirow{2}{*}{12} & Não-livre & 3 & 3 & 3 \\
\hline & Livre & 0 & 0 & 0 \\
\hline \multirow{2}{*}{13} & Não-livre & 3 & 3 & 3 \\
\hline & Livre & 0 & 0 & 0 \\
\hline \multirow{2}{*}{14} & Não-livre & 3 & 3 & 3 \\
\hline & Livre & 0 & 0 & 0 \\
\hline \multirow{2}{*}{15} & Não-livre & 3 & 3 & 3 \\
\hline & Livre & 1 & 0 & 0 \\
\hline \multirow{2}{*}{16} & Não-livre & 3 & 3 & 3 \\
\hline & Livre & 0 & 0 & 0 \\
\hline \multirow{2}{*}{17} & Não-livre & 3 & 3 & 3 \\
\hline & Livre & 1 & 0 & 0 \\
\hline
\end{tabular}

Escores: 0 = ausência de biofilme; 1 = 1 a 100 colônias/biofilmes; 2 = + 100 colônias/biofilmes; 3 = incontável 
Tabela 4 - Formação de biofilme in situ por estreptococos do grupo mutans (escores) nos fios (vestibular e palatino) dos aparelhos disjuntores de Haas do Grupo II (uso de Periogard ${ }^{\circledR}$ ).

\begin{tabular}{|c|c|c|}
\hline Espécime & Fio vestibular & Fio palatino \\
\hline 1 & 3 & 1 \\
\hline 2 & 0 & 0 \\
\hline 3 & 1 & 1 \\
\hline 4 & 1 & 1 \\
\hline 5 & 3 & 3 \\
\hline 6 & 0 & 0 \\
\hline 7 & 0 & 0 \\
\hline 8 & 3 & 3 \\
\hline 9 & 1 & 3 \\
\hline 10 & 0 & 1 \\
\hline 11 & 0 & 0 \\
\hline 12 & 0 & 0 \\
\hline 13 & 0 & 0 \\
\hline 14 & 1 & 0 \\
\hline 15 & 0 & 0 \\
\hline 16 & 3 & 1 \\
\hline 17 & 3 & 3 \\
\hline
\end{tabular}

Escores: 0 = ausência de biofilme; 1 = 1 a 100 colônias/biofilmes;

$2=+100$ colônias/biofilmes; $3=$ incontável 
Figura 5 - CULTURA MICROBIANA - GRUPO I (CONTROLE)

A e B - Intenso desenvolvimento de colônias/biofilmes de estreptococos do grupo mutans sobre as superfícies não-livres (A) e livres (B) do aparelho disjuntor de Haas.

C e D - Vista aproximada das colônias/biofilmes sobre a superfície não-livre (C) e livre (D) do parafuso.

E e F - Vista aproximada das colônias/biofilmes sobre a superfície livre (E) e nãolivre (F) da banda ortodôntica.

G - Colônias/biofilmes de estreptococos do grupo mutans sobre a superfície do acrílico, banda, fio vestibular e fio palatino. 

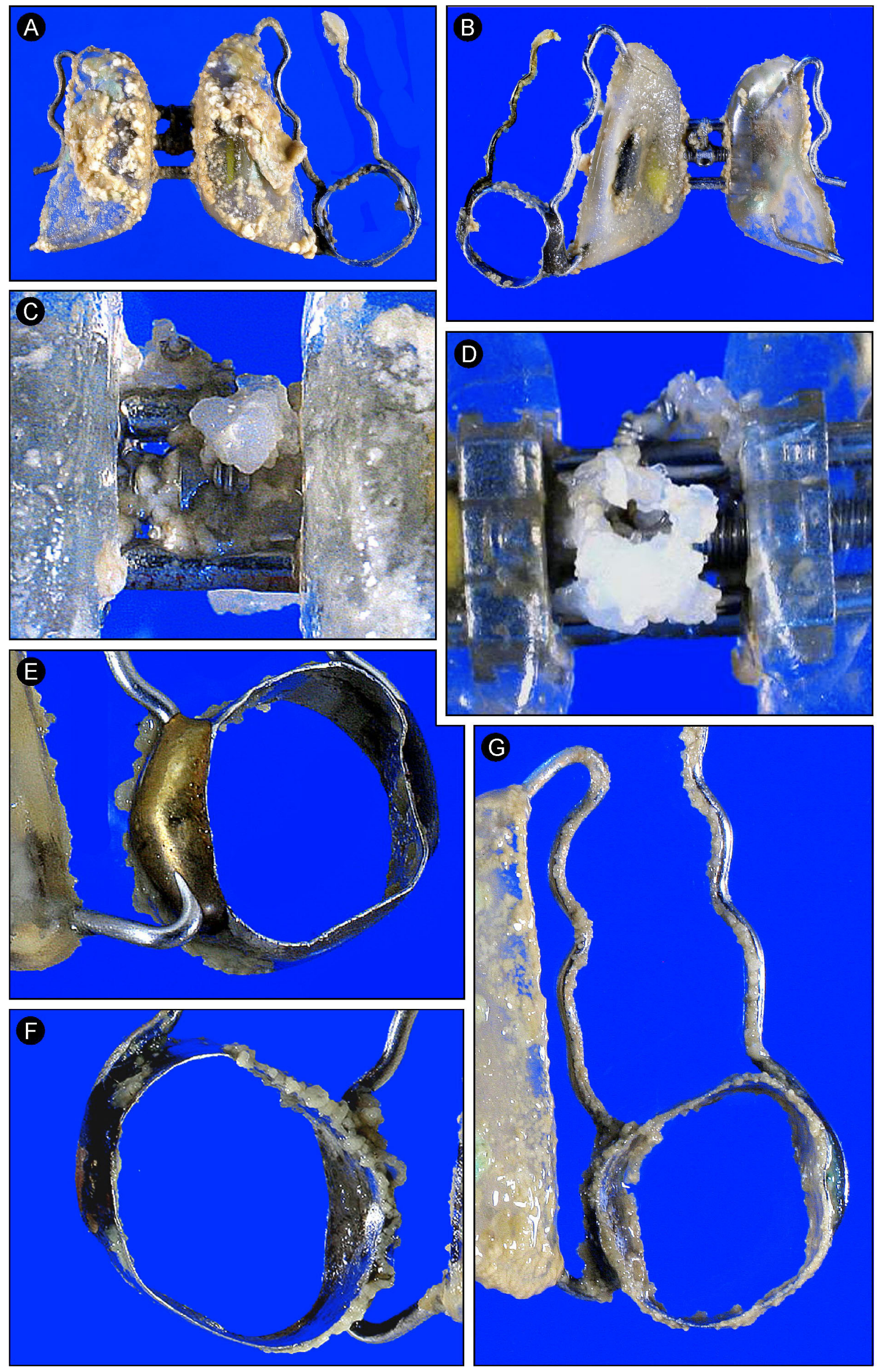
Figura 6 - CULTURA MICROBIANA - GRUPO I (CONTROLE)

A a H - Presença de grande número de colônias/biofilmes de estreptococos do grupo mutans sobre as superfícies do acrílico (A, B, D, E e F), parafuso expansor ( $A$ e $F)$, banda ortodôntica $(C, G$ e $H)$, fio palatino $(A, B$, e $F)$ e fio vestibular ( $A$ e $C)$. 

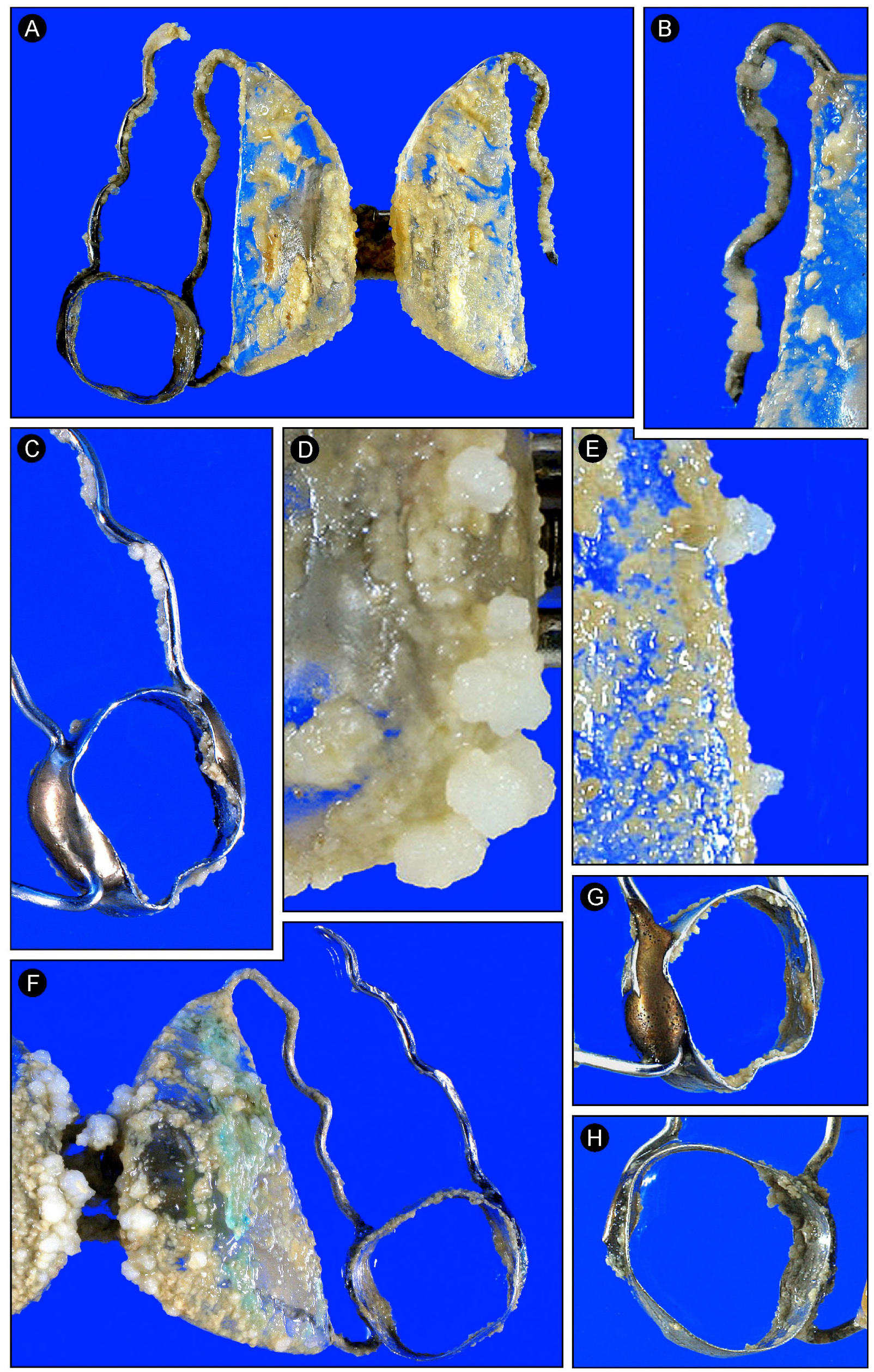


\section{Figura 7 - CULTURA MICROBIANA - GRUPO II (GLUCONATO DE CLOREXIDINA 0,12\%)}

A - Intenso desenvolvimento de colônias/biofilmes de estreptococos do grupo mutans sobre a superfície não-livre do aparelho disjuntor de Haas.

B - Presença de número reduzido de colônias/biofilmes de estreptococos do grupo mutans sobre a superfície livre do aparelho disjuntor de Haas.

C - Vista aproximada do grande número de colônias/biofilmes sobre a superfície não-livre da banda ortodôntica.

D - Vista aproximada da ausência de colônias/biofilmes sobre a superfície livre da banda ortodôntica.

E- Pequeno número de colônias/biofilmes sobre a superfície dos fios vestibular e palatino.

F - Vista aproximada do intenso desenvolvimento de colônias/biofilmes sobre a superfície não-livre do parafuso.

G - Vista aproximada da ausência de colônias/biofilmes de estreptococos do grupo mutans sobre a superfície livre do parafuso. 

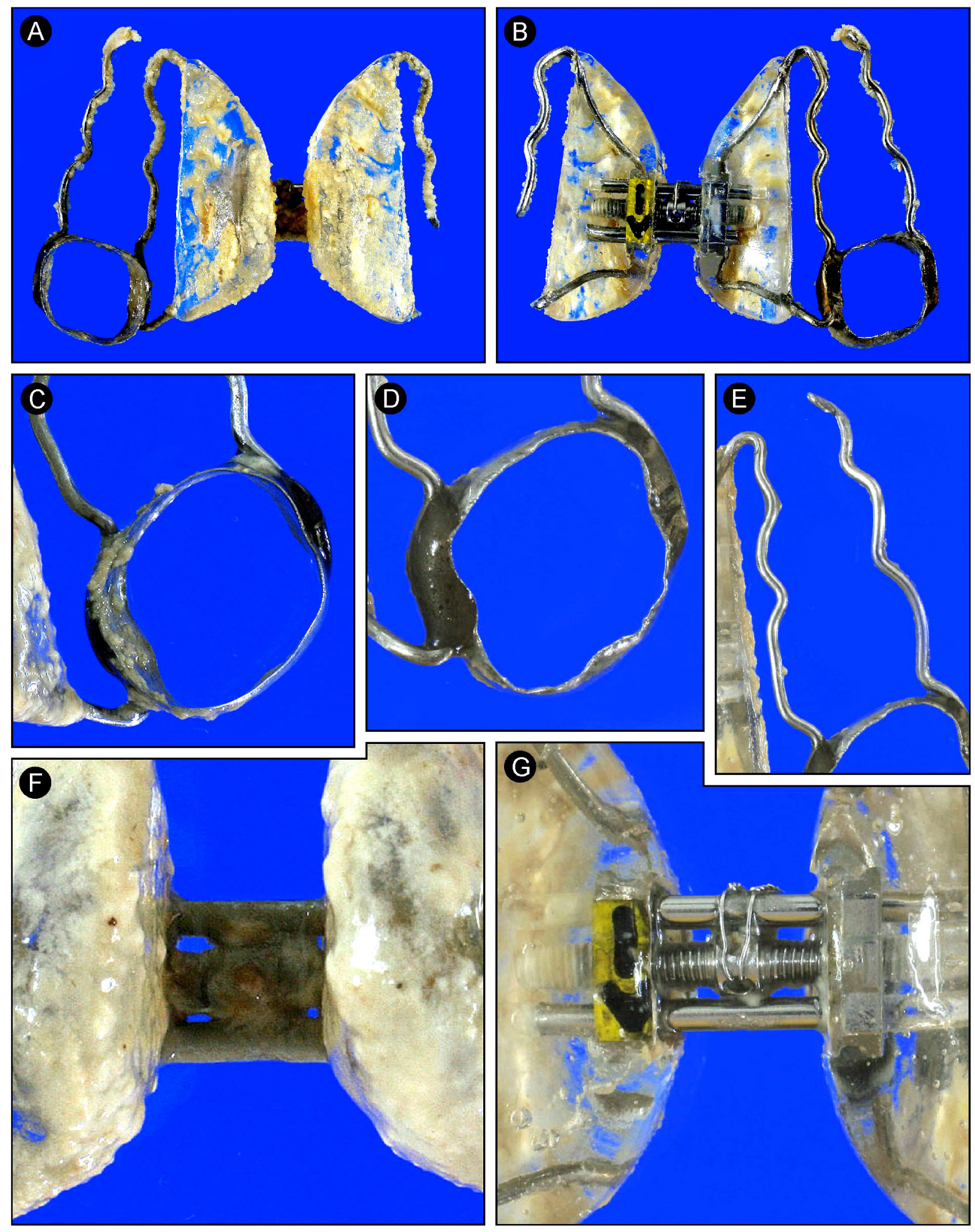
As tabelas 5 e 6 e as figuras 8, 9 e 10 apresentam o resultado da comparação entre os dois grupos, para os fios (vestibular e palatino) e para as superfícies livres e nãolivres das áreas do parafuso, acrílico e banda, em relação aos escores da formação ou não de colônias/biofilmes de estreptococos do grupo mutans.

Com relação às superfícies livres dos Grupos I e II, a comparação evidenciou diferença estatisticamente significante entre os 2 grupos, em todas as áreas analisadas (parafuso, acrílico e bandas) $(\mathrm{p}<0,001)$.

No entanto, quando as superfícies não-livres dos grupos I e II foram comparadas, não houve diferença entre os grupos $(p=0,009)$.

Os resultados obtidos evidenciaram a eficácia da clorexidina no controle do biofilme, in situ, nas superfícies livres, ou seja, porção extra-sulcular da banda $(p<0,001)$ e áreas da resina acrílica $(p<0,001)$ e do parafuso $(p<0,001)$ voltadas para a cavidade bucal. Além disso, a clorexidina reduziu a contaminação dos fios vestibular e palatino $(p<0,001)$. No entanto, observamos que nos espécimes do Grupo II a clorexidina não foi eficaz na área intra-sulcular da banda $(p=0,999)$ e nas áreas da resina acrílica $(p=0,999)$ e do parafuso $(p=0,999)$ voltadas para o palato.

Pôde-se verificar que o Periogard $^{\circledR}$ (Grupo II), de maneira geral, reduziu a formação de colônias/biofilmes nas superfícies livres dos aparelhos ortodônticos, tendo em vista que os escores desse grupo foram estatisticamente diferentes $(p<0,001)$ do Grupo I (controle).

Tabela 5 - Comparação entre o Grupo I (Controle, $n=17$ ) e Grupo II (uso de Periogard ${ }^{\circledR} n=17$ ), na região de fios (vestibular e palatino).

\begin{tabular}{|c|c|c|c|c|c|c|c|}
\hline \multirow[b]{2}{*}{ Fio Palatino } & \multicolumn{3}{|c|}{ Grupo I } & \multicolumn{3}{|c|}{ Grupo II } & \multirow[b]{2}{*}{$\begin{array}{c}p= \\
<0.0001\end{array}$} \\
\hline & $\begin{array}{c}\text { Med } \\
3\end{array}$ & $\begin{array}{c}\text { Q1- Q3 } \\
\text { 3-3 }\end{array}$ & $\begin{array}{c}\text { Min - Max } \\
3-3\end{array}$ & $\begin{array}{c}\text { Med } \\
0\end{array}$ & $\begin{array}{c}\text { Q1-Q3 } \\
0-1\end{array}$ & $\begin{array}{c}\text { Min - Max } \\
0-3\end{array}$ & \\
\hline Fio Vestibular & 3 & $3-3$ & $1-3$ & 1 & $0-3$ & $0-3$ & $<0.0001$ \\
\hline
\end{tabular}


Tabela 6 - Comparação entre o Grupo I (Controle, $n=17$ ) e Grupo II (uso de Periogard ${ }^{\circledR} n=17$ ), nas áreas do parafuso, da resina acrílica e da banda.

\begin{tabular}{|c|c|c|c|c|c|c|c|}
\hline \multirow[b]{3}{*}{$\begin{array}{l}\text { Banda (superfície } \\
\text { livre) }\end{array}$} & \multicolumn{3}{|c|}{ Grupo I } & \multicolumn{3}{|c|}{ Grupo II } & \multirow[b]{2}{*}{$p=$} \\
\hline & Med & Q1- Q3 & Min - Max & Med & Q1-Q3 & Min - Max & \\
\hline & 3 & $3-3$ & $3-3$ & 3 & $3-3$ & $3-3$ & 0.9999 \\
\hline $\begin{array}{l}\text { Banda (superfície } \\
\text { não-livre) }\end{array}$ & 3 & $3-3$ & $3-3$ & 0 & $0-0$ & $0-1$ & $<0.0001$ \\
\hline $\begin{array}{l}\text { Acrílico (superfície } \\
\text { livre) }\end{array}$ & 3 & $3-3$ & $3-3$ & 3 & $3-3$ & $3-3$ & 0.9999 \\
\hline $\begin{array}{l}\text { Acrílico (superfície } \\
\text { não-livre) }\end{array}$ & 3 & $3-3$ & $3-3$ & 0 & $0-0$ & $0-1$ & $<0.0001$ \\
\hline $\begin{array}{l}\text { Parafuso (superfície } \\
\text { livre) }\end{array}$ & 3 & $3-3$ & $0-3$ & 3 & $3-3$ & $0-3$ & 0.9999 \\
\hline $\begin{array}{l}\text { Parafuso (superfície } \\
\text { não-livre) }\end{array}$ & 3 & $1-3$ & $1-3$ & 0 & $0-1$ & $0-3$ & $<0.0001$ \\
\hline
\end{tabular}

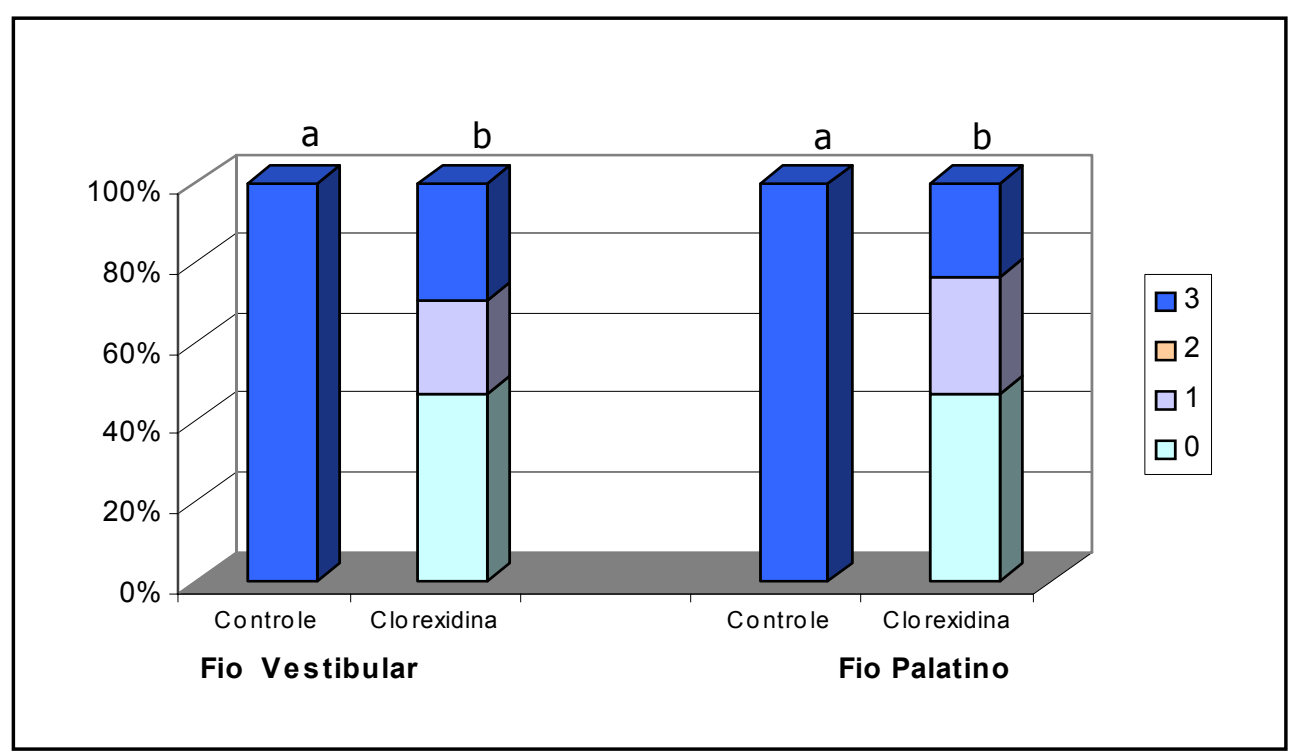

Figura 8 - Comparação entre os escores de formação do biofilme no Grupo I (Controle, $n=17$ ) e Grupo II (uso de Periogard ${ }^{\circledR} n=17$ ), na região de fios ortodônticos (vestibular e palatino). As letras $(a ; b)$ iguais e diferentes representam resultados estatísticos semelhantes e diferentes, respectivamente, entre os grupos I e II. 


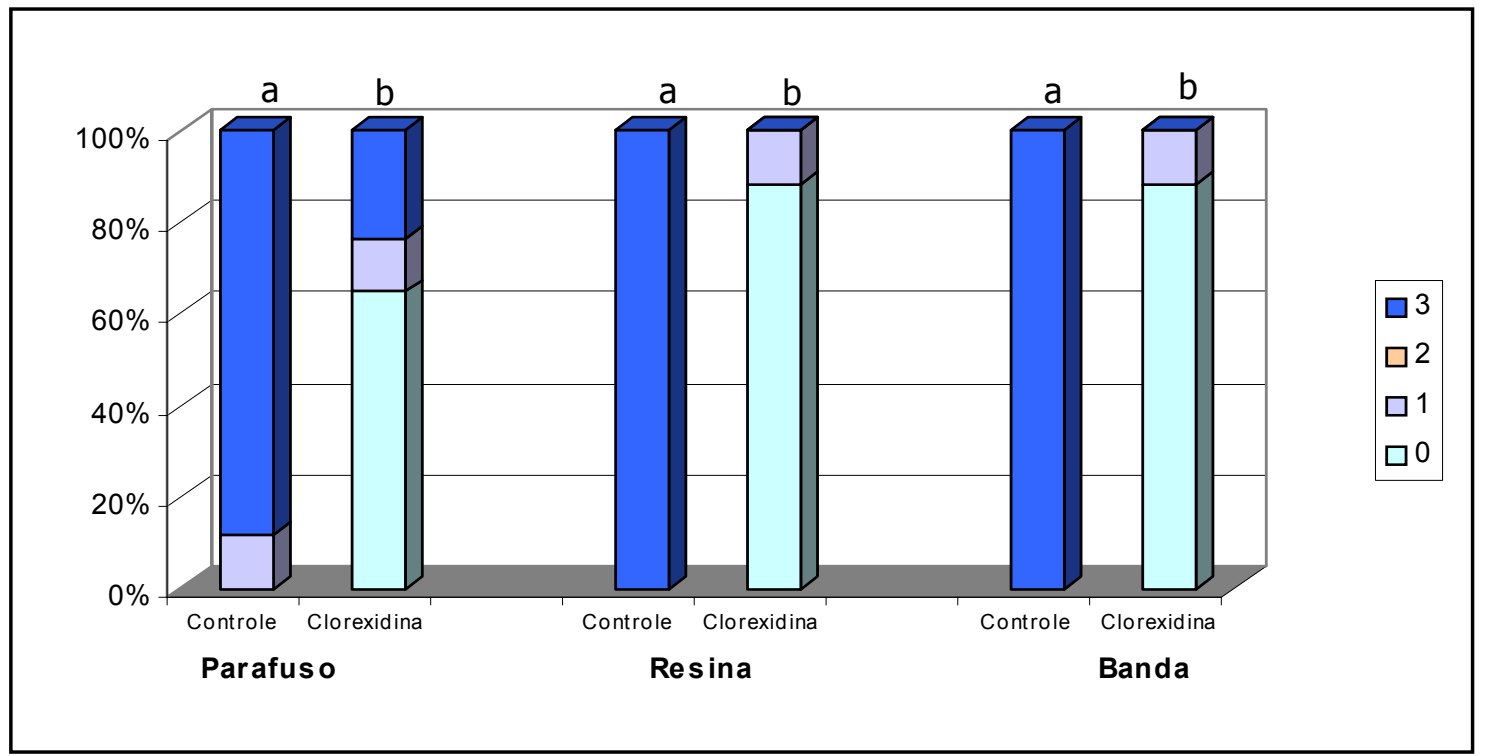

Figura 9 - Comparação entre os escores de formação do biofilme nas superfícies livres do Grupo I (Controle, $n=17$ ) e Grupo II (uso de Periogard ${ }^{\circledR} n=17$ ), das áreas do parafuso, do acrílico e da banda. As letras $(a ; b)$ iguais e diferentes representam resultados estatísticos semelhantes e diferentes, respectivamente, entre os grupos I e II.

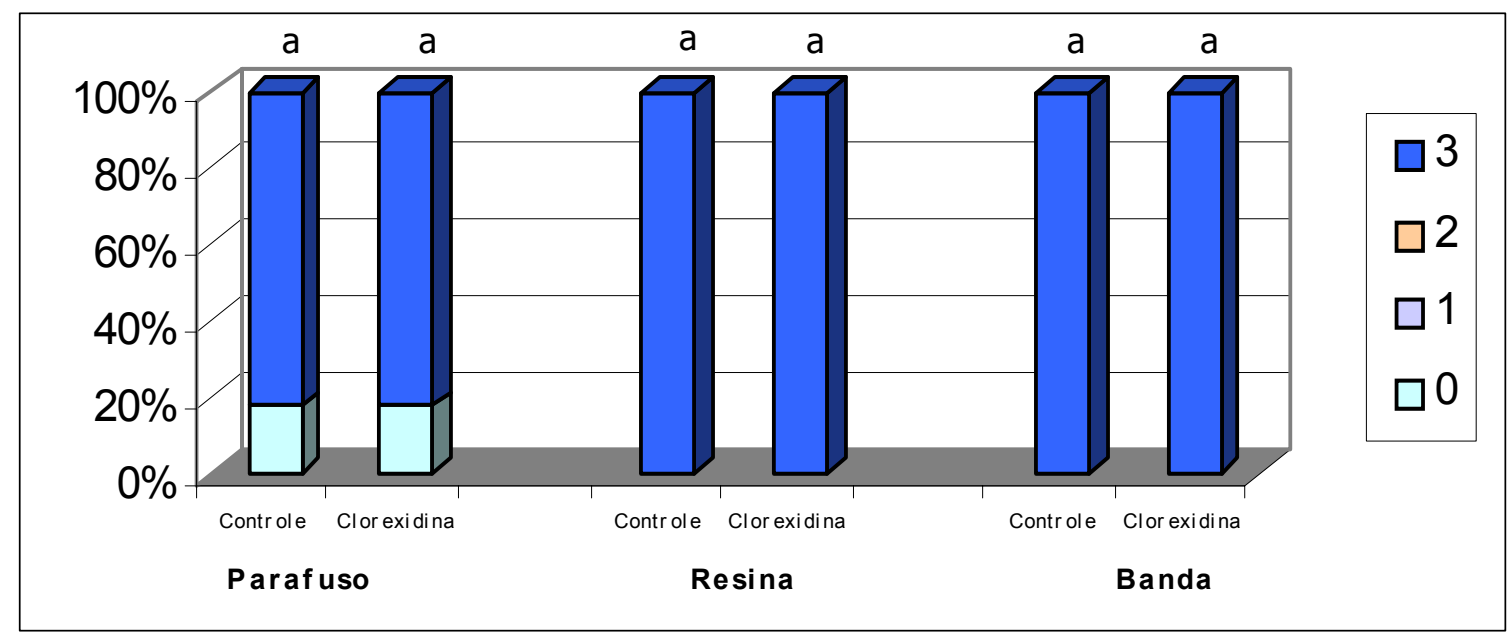

Figura 10 - Comparação entre os escores de formação do biofilme nas superfícies não livres do Grupo I (Controle, $n=17$ ) e Grupo II (uso de Periogard ${ }^{\circledR} n=17$ ), das áreas do parafuso, do acrílico e da banda. As letras iguais (a) representam resultados estatísticos semelhantes entre os grupos I e II.

\section{Confirmação da Identidade Microbiana}

A semeadura de colônias com morfologia macro e microscópica característica, no meio de cultura $\mathrm{SB}_{20}$ modificado, confirmou que as colônias que se desenvolveram nas superfícies dos aparelhos ortodônticos disjuntores de Haas eram realmente pertencentes ao grupo mutans. 


\subsection{Da avaliação da formação de biofilme in situ - Microscopia Eletrônica de Varredura}

Após cultura microbiana, a análise em microscópio eletrônico de varredura das diferentes áreas (acrílico, bandas, parafusos e fios) de 6 aparelhos ortodônticos representativos de cada grupo (controle e Periogard ${ }^{\circledR}$ ), evidenciou que:

- Quando a cultura microbiana foi positiva, com evidenciação de colônias/biofilmes ao microscópio estereoscópico, observou-se também a formação de biofilme bacteriano na superfície do aparelho, em MEV (Figuras 11 B-C, 11 E-H, 12 B-C, 12 E-F, 13B e 13 E-G).

- Nos casos onde não houve formação de colônias/biofilmes ao microscópio estereoscópico, observou-se na MEV ausência de colônias/biofilmes (Figuras 11D, $12 \mathrm{G}$ e $13 \mathrm{H}$ ) ou apenas a presença de microrganismos esparsos (Figuras 12D, 13C e 13I). Esse fato ocorreu apenas nos espécimes do Grupo II. 
Figura 11 - MICROSCOPIA ELETRÔNICA DE VARREDURA APÓS CULTURA MICROBIANA - BANDAS ORTODÔNTICAS - GRUPOS I e II.

A - Banda ortodôntica metalizada em ouro sob vácuo.

B, C, E, F, G e H - Eletromicrografias evidenciando a intensa formação de colônias/biofilmes, em espécimes do Grupo I. Aumentos de 60 a 25000x.

D - Eletromicrografia evidenciando ausência da formação de colônias/biofilmes, em espécime do Grupo II. Aumento de 60x. 

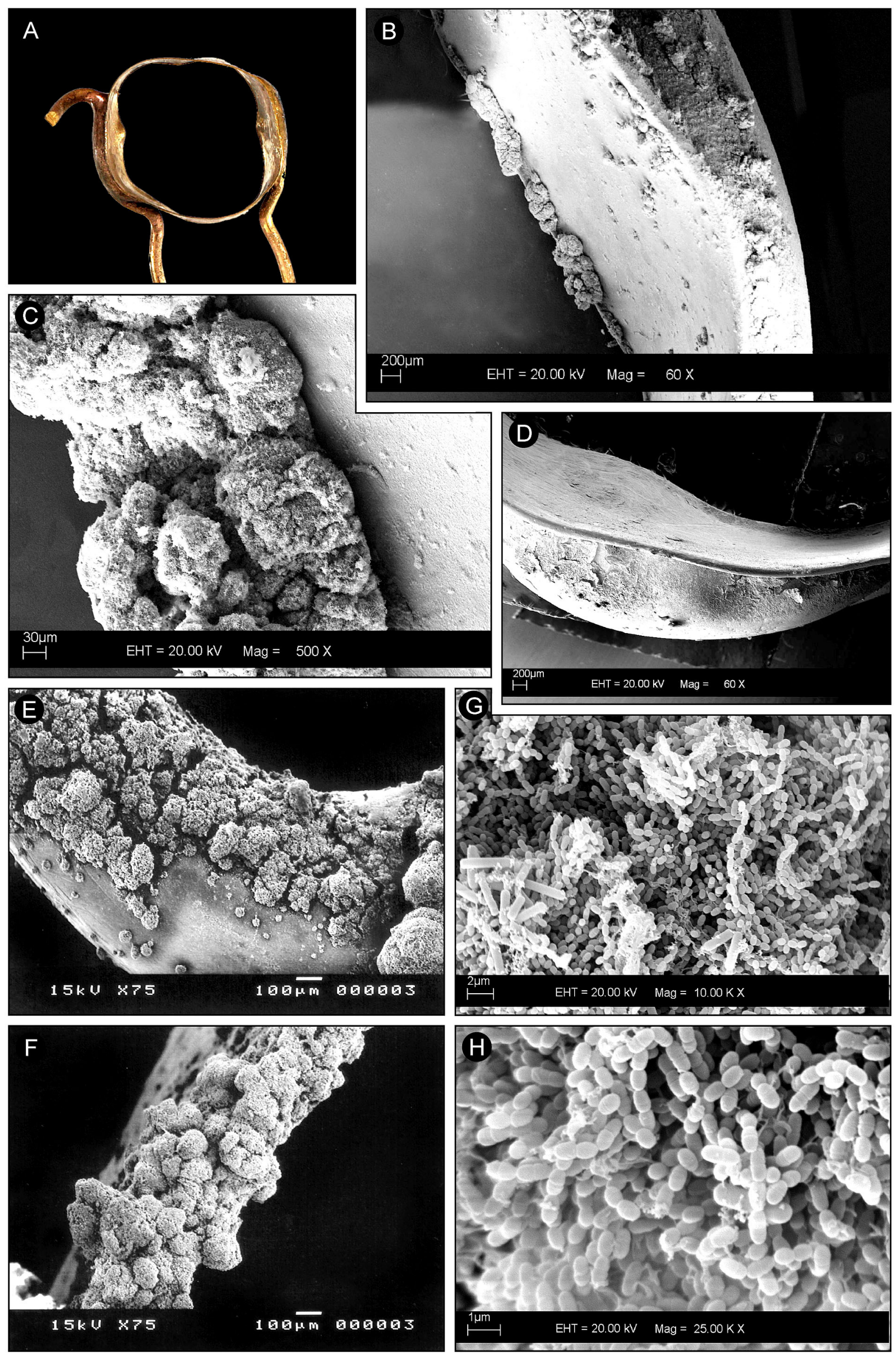
Figura 12 - MICROSCOPIA ELETRÔNICA DE VARREDURA APÓS CULTURA MICROBIANA - FIOS ORTODÔNTICOS - GRUPOS I e II.

A - Fio ortodôntico metalizado em ouro sob vácuo.

B, C, E e F - Eletromicrografias evidenciando a intensa formação de colônias/biofilmes, em espécimes do Grupo I. Aumentos de 15 a 20000x.

D e G - Eletromicrografia evidenciando a formação esparsa (D) ou ausência (G) de colônias/biofilmes, em espécimes do Grupo II. Aumento de 200x. 


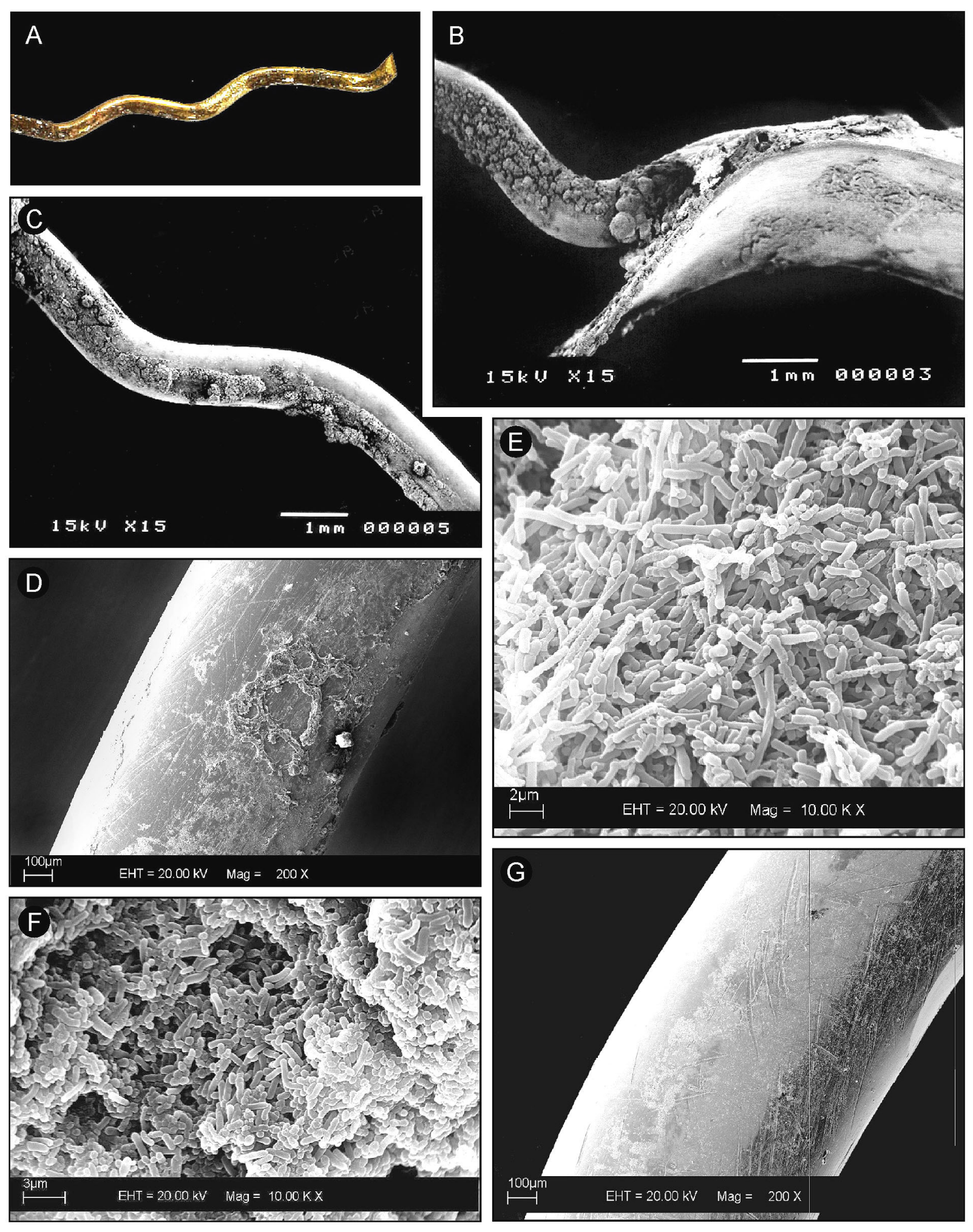




\section{Figura 13 - MICROSCOPIA ELETRÔNICA DE VARREDURA APÓS CULTURA MICROBIANA - RESINA ACRÍLICA E PARAFUSO EXPANSOR - GRUPOS I e II.}

A - Acrílico metalizado em ouro sob vácuo.

B - Eletromicrografia evidenciando a intensa formação de colônias/biofilmes, em espécime do Grupo I. Aumento de 10000x.

C - Eletromicrografia evidenciando formação esparsa de colônias/biofilmes, em espécime do Grupo II. Aumento de 5000x.

D - Parafuso expansor metalizado em ouro sob vácuo.

E, F e G - Eletromicrografias evidenciando a intensa formação de colônias/biofilmes, em espécimes do Grupo I. Aumentos de 55 a 25000x.

H, I - Eletromicrografias evidenciando ausência (H) ou formação esparsa (I) de colônias/biofilmes, em espécimes do Grupo II. Aumento de 60 e 3000x. 

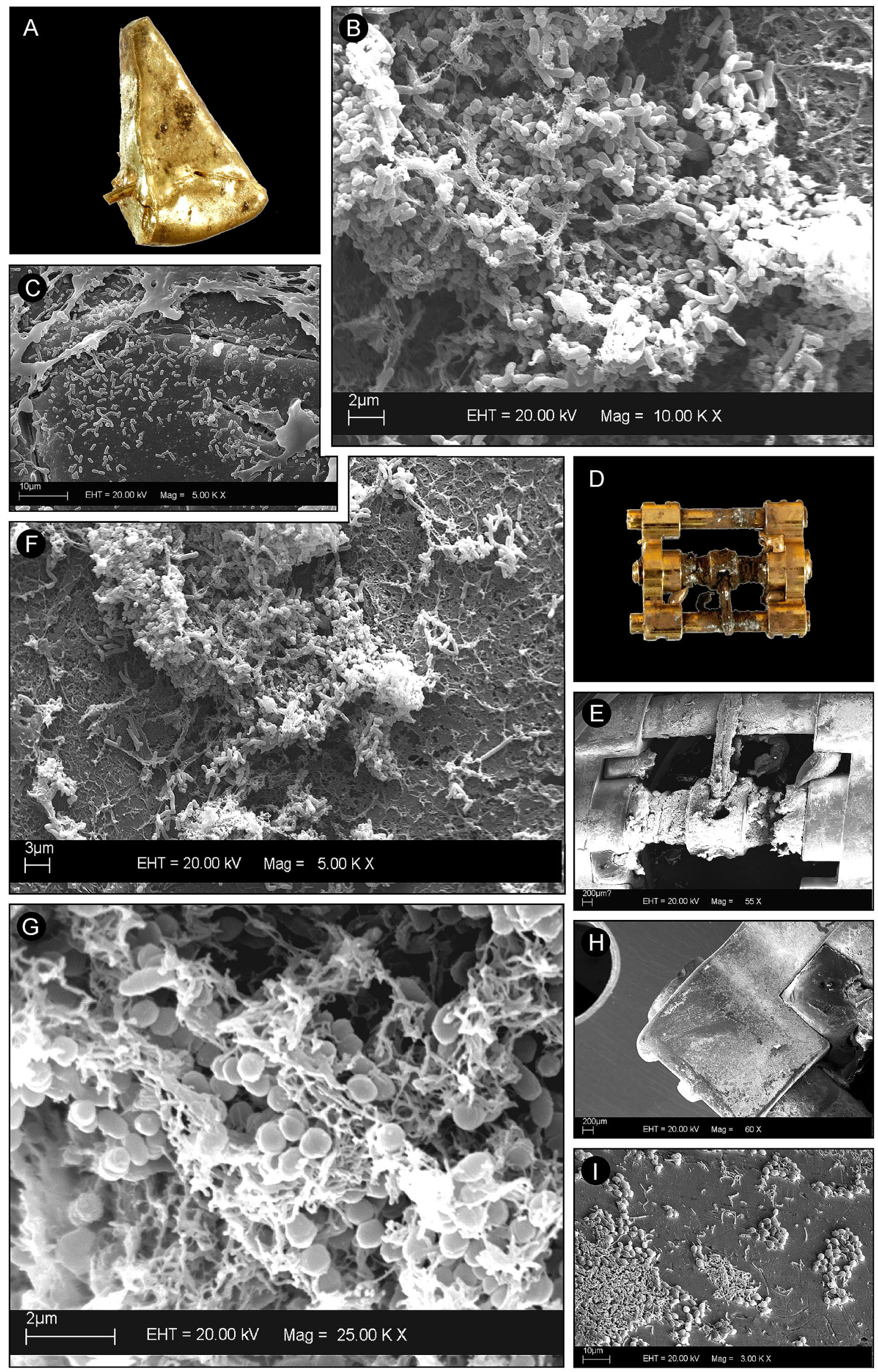


\subsection{Da avaliação da presença de corrosão in situ - Estereomicroscopia Ótica, Microscopia Eletrônica de Varredura (MEV) e Espectrometria de Energia Dispersiva (EDS)}

A análise das fotografias obtidas em estereomicroscopia ótica evidenciou a presença de áreas de alteração de coloração sugestivas de corrosão na região de solda em contato com a banda e com o fio, em regiões onde havia falhas na justaposição dos materiais em contato, em todos os espécimes de ambos os grupos (I e II) (Figuras 14 A-B), sem diferença estatística entre eles $(p=1)$.

As regiões que sugeriram presença de corrosão foram submetidas à avaliação em MEV (Figuras 14 C-D) com análise em EDS (Figuras 14 E-F), a fim de identificar os picos dos elementos químicos níquel ( $\mathrm{Ni})$, ferro $(\mathrm{Fe})$, cromo $(\mathrm{Cr})$ e oxigênio $(\mathrm{O})$, presentes nas áreas selecionadas. 
Figura 14 - ESTEREOMICROSCOPIA, MICROSCOPIA ELETRÔNICA DE VARREDURA E ESPECTROMETRIA DE ENERGIA DISPERSIVA (EDS).

A - Estereomicroscopia evidenciando alteração de coloração na união banda/solda/fio. Aumento de 20x.

B - Vista aproximada da alteração de coloração sugestiva de corrosão na união banda/solda. Aumento de 40x.

C e D - Eletromicrografias evidenciando a região da união banda/solda/fio a ser analisada em EDS. Aumentos de 60 e 194x.

E - Áreas da solda de prata (a), da justaposição dos diferentes materiais em contato (b) e do fio ortodôntico (c), analisadas em EDS com dectores QBSD.

F - Gráficos representativos das leituras qualitativas das áreas da solda de prata (a), da justaposição dos diferentes materiais em contato (b) e do fio ortodôntico (c), evidenciando como se comportam os picos dos elementos químicos. 


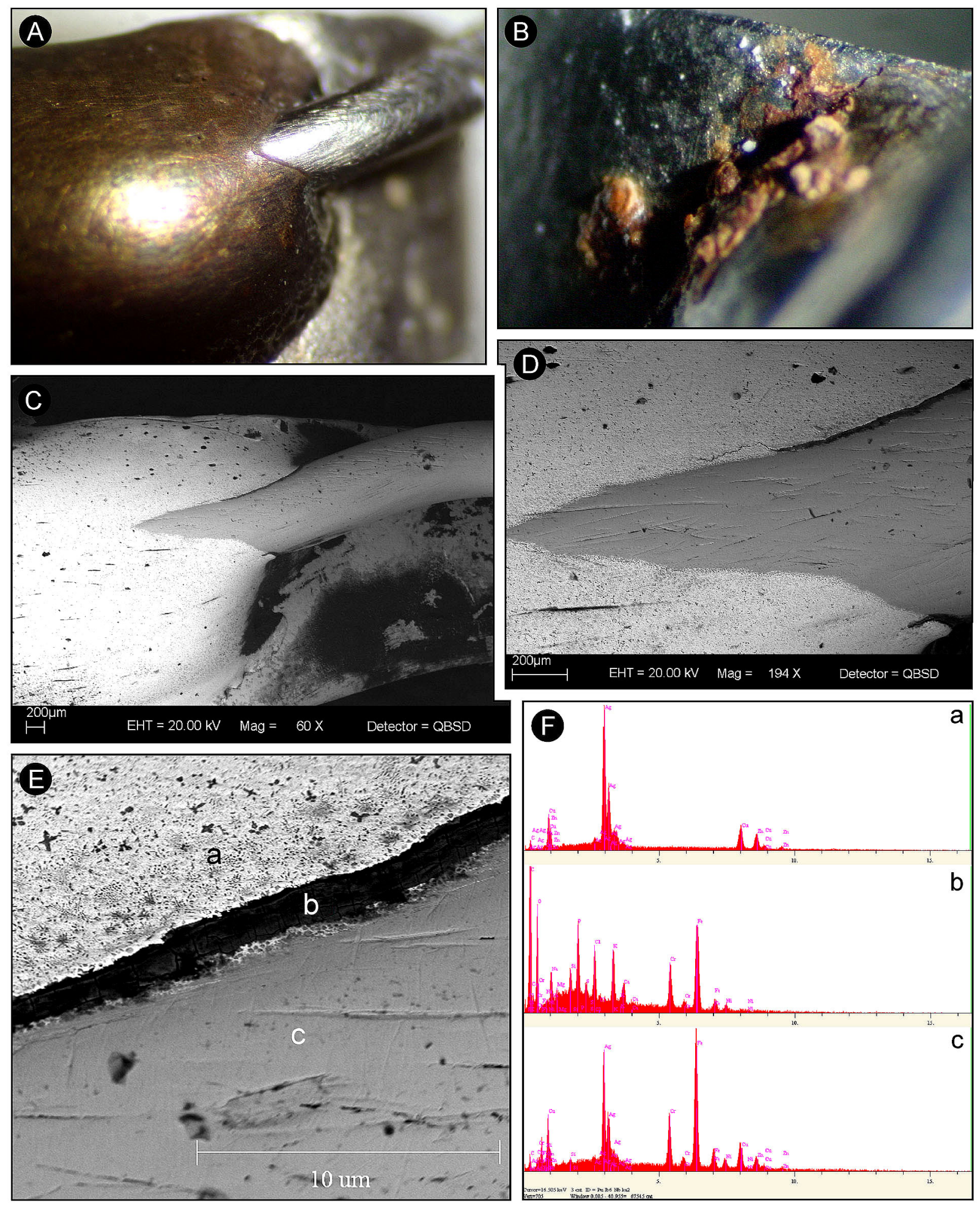


Gráficos representativos das leituras qualitativas dos espécimes dos grupos I e II estão apresentados nas Figuras 15 e 16.

Observou-se, nos espécimes de ambos os grupos (I e II), que as áreas de solda em contato com as bandas e com os fios, apresentaram picos de ferro (Fe), cromo $(\mathrm{Cr})$, oxigênio $(\mathrm{O})$, carbono $(\mathrm{C})$ e fósforo $(\mathrm{P})$. Não foram observados picos expressivos de níquel (Ni) em nenhum dos grupos (I e II).

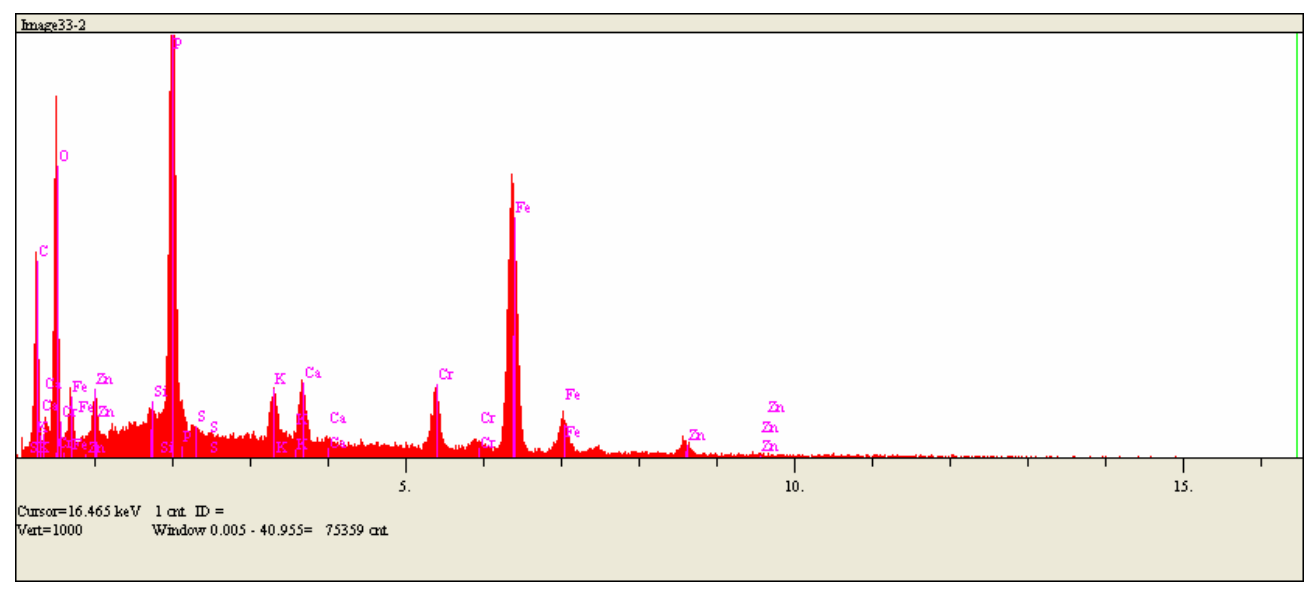

Figura 15 - Leitura quantitativa em EDS, representativa das áreas de alteração de coloração sugestivas de corrosão na região de solda em contato com a banda e com o fio, em espécime do Grupo I (controle).

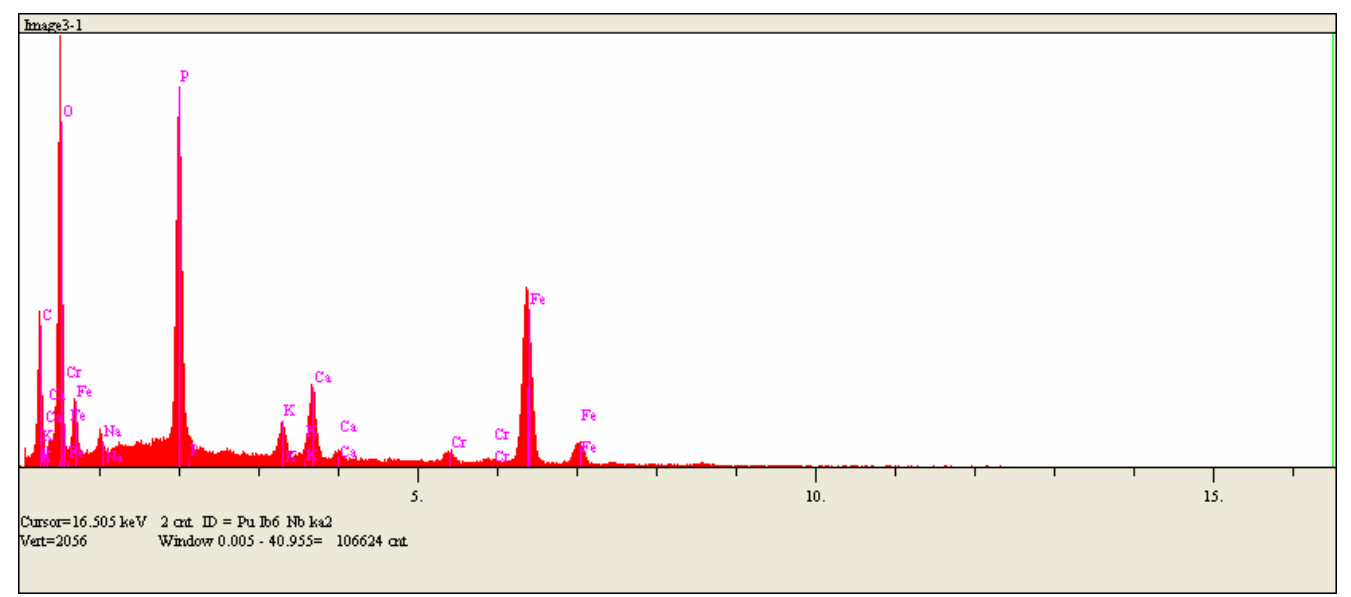

Figura 16 - Leitura quantitativa em EDS, representativa das áreas de alteração de coloração sugestivas de corrosão na região de solda em contato com a banda e com o fio, em espécime do Grupo II (uso de Periogard ${ }^{\circledR}$ ). 
A presença de picos de prata $(\mathrm{Ag})$ nos gráficos de áreas da solda distantes das falhas entre os materiais em contato sugeriram apenas a composição da liga, sem presença de corrosão. Os picos de $\mathrm{Fe}$ e $\mathrm{Cr}$ altos e equivalentes indicam a composição do aço (fio) e ausência de corrosão. A figura 17 ilustra a leitura obtida em uma região do fio ortodôntico do disjuntor de Haas com ausência de corrosão visível ao estereomicroscópio ótico, evidenciando como se comportaram os picos dos elementos químicos, nessa situação.

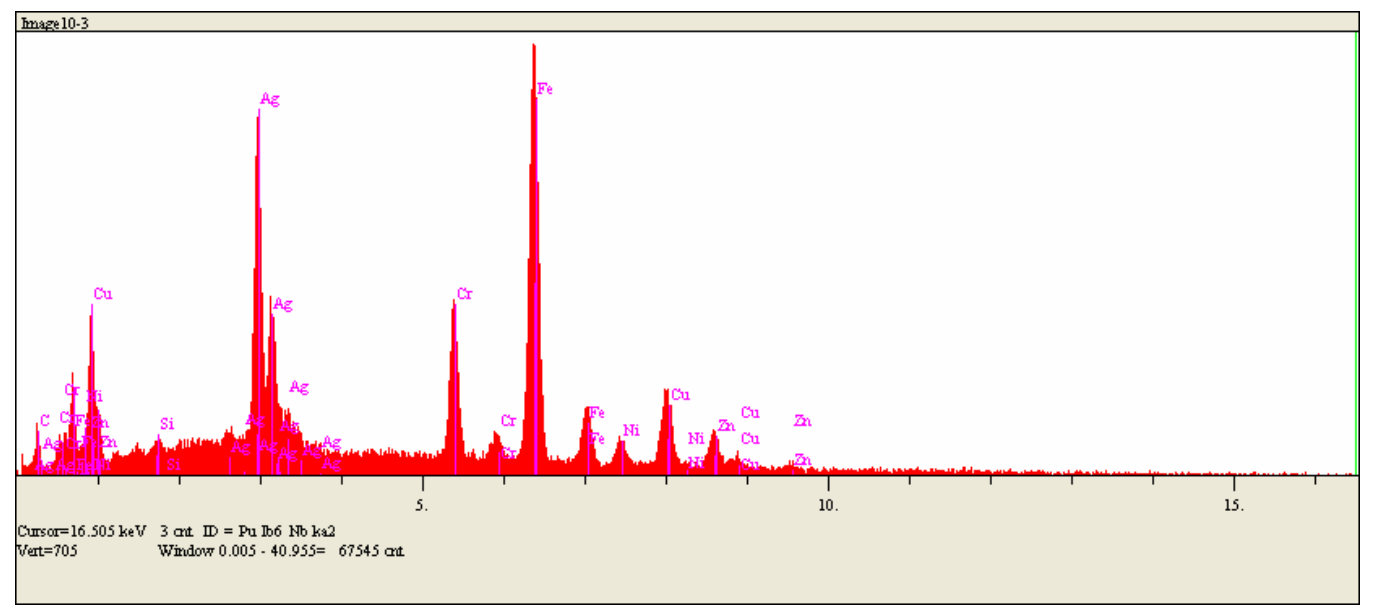

Figura 17 - Leitura quantitativa da composição do aço (fio) com ausência de corrosão.

Pelo exposto, os resultados obtidos permitem inferir que o uso da clorexidina (Grupo II) reduziu a formação de biofilme nos aparelhos analisados, sem elevar os índices de corrosão in situ, com relação ao grupo controle (Grupo I). 


\section{DISCUSSÃO}




\section{Discussão}

\subsection{Da Metodologia}

O aparelho de Haas é um expansor muco-dento-suportado, constituído de parafuso expansor, acrílico na região do palato e hastes metálicas constituídas de fios de aço inoxidável que contornam os dentes tanto pela face vestibular quanto pela face palatina, soldadas a bandas nos dentes de apoio (Haas, 1970). É um método rotineiro de tratamento ortodôntico em crianças e adolescentes, utilizado por vários autores, visando a correção de problemas transversais na maxila (Graber, 1966; Handelman et al., 2000; Cameron et al., 2002; Oliveira et al., 2004; Chung et al., 2004; Lima et al., 2005; Bolan et al., 2005; Silva Filho et al., 2007).

O aparelho é mantido na cavidade bucal por um período de tempo total considerável, estando sujeito à formação de biofilme bacteriano e corrosão. Por essa razão, selecionamos para avaliação nesse estudo pacientes que necessitavam de aparelhos disjuntores de Haas. Adicionalmente, optamos pela realização de um estudo clínico randomizado, pois esse representa o "padrão ouro" (delineamento ideal) das pesquisas que avaliam a eficácia clínica de materiais e técnicas de tratamento (Fletcher et al., 2002).

Embora a cavidade bucal apresente inúmeras espécies de microrganismos (Fejerskov e Kidd, 2005), avaliamos apenas a presença de estreptococos do grupo mutans, em função desses serem considerados os agentes etiológicos primários da cárie dental (Ajdic et al., 2002; Berkowitz, 2003; Fejerskov e Kidd, 2005) e de serem os microrganismos que mais comumente contaminam os aparelhos ortodônticos (Sreenivasan et al., 2004; Ahn et al., 2007).

A contaminação microbiana dos aparelhos ortodônticos pode, à semelhança do que ocorre com as escovas dentais, sofrer a influência do tipo de dentifrício utilizado. Quando o dentifrício apresenta agentes antimicrobianos como o triclosan em sua composição, há uma considerável redução desta contaminação (Sreenivasan et al., 2004; Nelson-Filho et al., 2004). Por essa razão, no presente estudo empregamos dentifrício contendo apenas flúor durante a escovação, em ambos os grupos, a fim de reduzir interferências nos resultados. Além disso, os pacientes do Grupo II efetuaram os bochechos com solução de gluconato de Clorexidina a $0,12 \%$ (Periogard $^{\circledR}$ ) em períodos distantes do momento da escovação dental, pois alguns autores (Jones, 1997; Kolahi e Soolari, 2006) 
relataram que o lauril sulfato de sódio e o monofluorfosfato de sódio, presentes nos dentifrícios, são incompatíveis com a clorexidina.

Os pacientes do Grupo II efetuaram bochechos com solução à base de clorexidina, duas vezes por semana, até a remoção do aparelho. Selecionamos esse agente antimicrobiano em função de ser o mais eficaz no controle da placa bacteriana e da gengivite (Rölla e Melsen, 1975; Addy, 1986; Jones, 1997; Auschill et al., 2005) e ser considerado o antimicrobiano "padrão ouro" (Jones, 1997; Mosrefi, 2002).

Segundo Featherstone (2006), a eficácia do uso domiciliar da clorexidina pode ter seu potencial subestimado, tendo em vista a necessidade da colaboração do paciente. No presente estudo, os pacientes do Grupo II realizaram 2 bochechos por semana com a clorexidina: um na FORP/USP, sob supervisão do pesquisador, e um em seu domicílio, sob supervisão do responsável, geralmente a mãe. Assim, os pacientes foram constantemente monitorados, o que minimizou também interferências nos resultados obtidos.

Para a avaliação microbiológica, em nosso estudo, não foi empregada a técnica de diluição, onde os espécimes são submetidos à agitação mecânica ou ultra-sônica para dessorção dos microrganismos e as suspensões resultantes são diluídas e semeadas em meio de cultura sólido. Os aparelhos foram incubados diretamente no meio de cultura líquido, para avaliação da formação do biofilme in situ sobre suas diferentes superfícies, como sugerido por Lessa et al. (2007), Magno et al. (2007) e Peixoto (2007).

Diferentes meios de cultura sólidos têm sido empregados para a detecção de estreptococos do grupo mutans, tais como o ágar MSB (Gold et al., 1973; Tedjosasongko e Kozai, 2002), o ágar SB 20 (Davey e Rogers, 1984; Sanches et al., 2001), o ágar SB $_{20}$ modificado (Azevedo, 1988; Torres et al., 1993), o MS-MUTV (Takada e Hirasawa, 2005) e o TYCSB (Wan et al., 2003), entre outros. Utilizamos o Caldo Sacarose Bacitracina (CaSa B), já empregado nos trabalhos de Sato et al. (2005), Brêtas et al. (2005), Nelson-Filho et al. (2006), Lessa et al. (2007), Magno et al. (2007) e Peixoto (2007), por ser este um meio de cultura líquido, seletivo enriquecedor, o qual possibilita o desenvolvimento do biofilme bacteriano diretamente sobre a superfície dos aparelhos ortodônticos. Este meio de cultura serve de substrato para os estreptococos do grupo mutans e limita o crescimento de outros tipos de microrganismos, em função da presença da sacarose e da bacitracina (antibiótico), em sua composição.

Para a avaliação da corrosão, empregamos análises in situ em estereomicroscopia, MEV e EDS, as quais são metodologias largamente utilizadas para a avaliação de propriedades tribológicas de materiais (Kim et al., 1999; Eliades et al., 2000; O'Hoy et al., 2003; Wichelhaus et al., 2004; Ferreira, 2005). 
A avaliação dos espécimes em MEV com análise em EDS é um método utilizado para avaliar a composição química dos materiais, comparando a intensidade de raios $X$ característicos, que são gerados pela irradiação de um feixe de elétrons específico sobre determinada área do espécime, identificando cada elemento químico presente na superfície. Trata-se de um método qualitativo rápido, fácil e não destrutivo (Suga et al., 2000), que tem sido empregado na área de Ortodontia para análise da composição e da ocorrência de corrosão em fios e brackets (Vinnichenko et al., 2003; Eliades et al., 2004; Gioka et al., 2004; Wichelhaus et al.,2004; Lin et al., 2006; Siargos et al., 2007).

A avaliação da corrosão foi efetuada apenas na área específica da união fio/banda/solda, baseada nos resultados do trabalho de Ferreira (2005). Esse autor avaliou in vitro a resistência à corrosão de materiais metálicos utilizados em aparelhos ortodônticos fixos com arcos ortodônticos pré-contornados de aço inoxidável, cromo-níquel, níquel-titânio e titânio-beta. Ensaios eletroquímicos, curvas de polarização anódica e corrente $x$ tempo foram realizados, seguidos por avaliação em microscopia ótica, MEV e EDS. O autor concluiu que os aparelhos ortodônticos fixos apresentaram resistência ao processo corrosivo, apesar da diversidade de materiais empregados na sua composição. O processo corrosivo foi observado apenas na região onde a solda a ponto foi utilizada para fixar o tubo terminal na banda molar, ambos materiais constituídos de aço inoxidável.

\subsection{Dos Resultados da avaliação da formação de biofilme in situ - Cultura Microbiana e MEV}

\section{Do Grupo I (Controle)}

Vários autores têm se preocupado em avaliar o efeito do uso de aparelhos ortodônticos nos níveis salivares de microrganismos ou no acúmulo de biofilme sobre os elementos dentais (Macpherson et al., 1990; Rosenbloom e Tinanoff, 1991; Anhoury et al., 2002; Ahn et al., 2002; Jordan e Leblanc, 2002; Leung et al., 2006; Sudjalim et al., 2007), o que eleva a probabilidade de desenvolvimento de lesões de cárie (Southard et al., 1986; Ulukapi et al., 1997; Steinberg e Eyal, 2004; Ahn et al., 2007).

No entanto, a presença de microrganismos, sob a forma de biofilme in situ, diretamente sobre a superfície dos materiais constituintes de aparelhos ortodônticos tem sido pouco estudada (Gwinnett e Ceen, 1979; Brêtas et al., 2005; Auschill et al., 2005; Peixoto, 2007; Lessa et al., 2007; Magno et al., 2007), envolvendo apenas brackets, 
ligaduras elastoméricas e placas de acrílico de aparelhos removíveis. Até o momento não há trabalhos publicados na literatura específica avaliando a contaminação microbiana por estreptococos do grupo mutans, in situ, em aparelhos disjuntores de Haas.

O aparelho disjuntor de Haas é composto de uma parte polimérica (resinosa) e de partes metálicas (bandas, fios e parafuso). Segundo Rosa et al. (2005), a dificuldade de higienização e o uso por períodos prolongados desse aparelho fixo favorecem a formação de um biofilme bacteriano de difícil remoção, situado em íntimo contato com a mucosa bucal, principalmente na área voltada para o palato (áreas do parafuso e do acrílico). Esses locais muitas vezes retêm restos alimentares e células descamadas, oferecendo condições ideais para o desenvolvimento de um biofilme estável. No presente estudo esse fato pôde ser observado nos pacientes tanto do Grupo I (controle) quanto do Grupo II (uso do Periogard ${ }^{\circledR}$ ) onde, no momento da remoção dos aparelhos da cavidade bucal, verificamos clinicamente a presença de acúmulo de resíduos e placa bacteriana, em grande quantidade, na área da resina acrílica voltada para o palato, causando inflamação nessa região.

Segundo Leung et al. (2006), o tratamento com aparelhos fixos pode aumentar a invasão de células epiteliais da cavidade bucal por microrganismos. Essa invasão é um importante fator de virulência, que dificulta ainda mais o controle desses microrganismos, inclusive pelo sistema imune do indivíduo.

No presente estudo, os 17 aparelhos do Grupo I apresentaram intensa contaminação por estreptococos do grupo mutans, em todas as superfícies livres (voltadas para a cavidade bucal) e as superfícies não-livres (em contato direto com a mucosa palatina e sulco gengival), incluindo bandas, acrílico e parafuso expansor, com predominância de escore 3 no estudo de cultura microbiana, comprovados em MEV. Esses resultados foram também observados nos fios (vestibular e palatino). A comparação desses resultados com a literatura específica somente é possível na área da placa de acrílico, tendo em vista a ausência de trabalhos publicados avaliando biofilme em outras partes de aparelhos fixos.

Com relação à parte polimérica (acrílica) dos aparelhos, o material mais comumente utilizado para sua confecção é o polimetilmetacrilato (PMMA), sob a forma de esferas de pó e monômero líquido (metilmetacrilato) (Jagger et al., 1999). A maneira como geralmente esses componentes são misturados pode levar a uma falta de uniformidade na conversão da matriz resinosa, com presença de monômero residual. Como resultado, pode haver descoloração da resina, possibilidade de reações alérgicas (Brantley e Eliades, 2001) e maior sorpção de água (Dogan et al., 1995), com interferência nas propriedades mecânicas dos polímeros. 
Assim, falhas nessa mistura podem favorecer o aparecimento de porosidades que, quando presentes na superfície do aparelho, dificultam ou impossibilitam sua limpeza diária adequada, permitindo a retenção de resíduos e o desenvolvimento de microrganismos, os quais podem penetrar e se manter viáveis a uma profundidade que varia de 1 a 2 micrometros (Davenport, 1972), se comportando como uma esponja (Martins-Ortiz et al., 2004). Segundo Arendorf e Addy (1985) e Jorge et al. (1987), o acrílico do aparelho, mesmo quando adequadamente polido, atua como uma superfície rígida não-descamativa, propícia à formação de biofilme, o que pode ser considerado um fator adicional para aquisição de estomatites, como infecções fúngicas na mucosa bucal.

Os resultados do presente estudo evidenciaram que as partes poliméricas dos disjuntores de Haas do Grupo I (controle) tornaram-se intensamente contaminadas por microrganismos, com exuberante desenvolvimento de biofilme, tanto na superfície livre quanto na superfície não-livre. Esses resultados são concordantes com os obtidos por Lessa et al. (2007) e Peixoto (2007), que observaram uma grande quantidade de colônias/biofilmes de estreptococos do grupo mutans na superfície de acrílico de aparelhos ortodônticos removíveis, em $100 \%$ dos pacientes do grupo controle, cujos aparelhos foram borrifados com água de torneira esterilizada, após serem utilizados por 7 dias.

Com relação às bandas metálicas, segundo Fulford et al. (2003), o simples ato de selecioná-las clinicamente, testando sua adaptação à estrutura dental, ocasiona sua contaminação por microrganismos oriundos da cavidade bucal. Nossos resultados evidenciaram que após permanecer em média por 4 meses na cavidade bucal, as bandas se encontraram altamente contaminadas por estreptococos do grupo mutans, com escore 3 em $100 \%$ dos casos.

Assim como no acrílico e nas bandas, nas demais áreas dos aparelhos do Grupo I (fios e parafuso), observamos intensa contaminação por estreptococos do grupo mutans sob a forma de biofilme in situ.

Assim, podemos afirmar que o método mecânico (escovação), isoladamente, mostrou-se ineficaz para a adequada remoção do biofilme bacteriano nos aparelhos disjuntores de Haas.

Esses dados apresentam relevância clínica, pois a falta de controle do acúmulo de microrganismos nesses locais favorece a instalação de um foco de infecção intrabucal, que não pode ser ignorado. Embora a simples presença do biofilme in situ não seja suficiente para predizer o desenvolvimento de lesões de cárie, a elevada quantidade de microrganismos cariogênicos observada em todos os espécimes do Grupo I nos permite inferir que os pacientes portadores de aparelhos ortodônticos fixos apresentam maior risco 
de desenvolver lesões de cárie. Assim, programas preventivos individuais, constando de orientação de higiene bucal mecânica (escovação e uso de fio dental) e química (uso de agentes antimicrobianos auxiliares no controle do biofilme), durante o tratamento ortodôntico, são essenciais.

Deve-se ressaltar, ainda, que nunca houve uma análise das conseqüências sistêmicas do uso de aparelhos contaminados, por longos períodos de tempo. Na realidade, na prática clínica da Ortodontia sequer valoriza-se, registra-se ou mensura-se um provável aumento na ocorrência primária ou recorrente de gripes, resfriados, candidoses, irritações da mucosa, amidalites e outras infecções oportunistas, durante o tratamento ortodôntico (Martins-Ortiz et al., 2004).

Um outro aspecto agravante é que os microrganismos podem ter acesso à corrente circulatória após procedimentos odontológicos, incluindo extrações dentais, cirurgias periodontais, raspagem, tratamento endodôntico e colocação/retirada de bandas ortodônticas.

A esse respeito, Rosa et al. (2005) avaliaram a ocorrência de bacteriemia após a remoção de aparelhos de Haas, salientando que há uma forte possibilidade de que o trauma ocorrido durante sua remoção possa ter correlação com bacteriemias transitórias. Esse fato implica na necessidade de cuidados adicionais, como antibioticoterapia profilática e uso de clorexidina previamente à remoção dos aparelhos, principalmente em pacientes especiais, incluindo aqueles que apresentam risco de complicações cardíacas ou risco de endocardite bacteriana.

Conforme salientado por Martins-Ortiz et al. (2004), no consultório odontológico não são tratados apenas pacientes sistemicamente saudáveis, mas também cardiopatas, diabéticos e imunodeprimidos, entre outros, justificando a necessidade de cuidados adicionais. Assim, em pacientes portadores de aparelhos ortodônticos fixos, os quais não podem ser removidos da boca para serem higienizados, o controle da contaminação microbiana por meio do uso de agentes químicos é fundamental, não apenas para reduzir o risco de doenças prevalentes como cárie dental e doença periodontal, mas também para preservar a saúde geral do paciente. 


\section{Do Grupo II (bochechos com Periogard ${ }^{\circledR}$ )}

Em função das dificuldades para o controle mecânico (escovação e uso do fio dental) do biofilme dental em pacientes ortodônticos, agentes químicos com ação sobre estreptococos do grupo mutans têm sido empregados como coadjuvantes (Gjermo et al., 1974). No entanto, as pesquisas são focadas apenas no controle químico dos microrganismos salivares e do biofilme desenvolvido sobre a superfície dental (Lundström et al.,1980; Brightman et al.,1991; Morrow et al.,1992; Anderson et al., 1997; Beyth et al., 2003), sendo o controle do biofilme na superfície dos aparelhos ortodônticos fixos por substâncias antimicrobianas, até o momento, um assunto pouco explorado.

A clorexidina é uma biguanida (Hidalgo e Dominguez, 2001) descoberta na década de 40 (Parson, 1974) que, a partir do estudo clássico de Löe et al. (1976), teve seu uso popularizado na Odontologia, particularmente em função do seu amplo espectro de ação, ou seja, sua eficácia contra microrganismos gram-positivos, gram-negativos, aeróbios, anaeróbios facultativos, leveduras e vírus (Hidalgo e Dominguez, 2001; Decker et al., 2005; Kara et al., 2006; Kolahi e Soolari, 2006). Uma característica importante é que os S. mutans são altamente sensíveis à clorexidina, como relatado por Emilson (1977), Kara et al. (2006) e Featherstone (2006).

A atividade antimicrobiana da clorexidina, in vivo, em parte é decorrente do seu efeito prolongado (substantividade), que é a propriedade de se adsorver, reversivelmente, à mucosa bucal, película dentária, proteínas salivares e hidroxiapatita (Rolla et al., 1975), sendo lentamente liberada na cavidade bucal por até 24 horas (Gjermo et aL, 1974). Quando utilizada topicamente, a clorexidina é uma substância segura, com baixo potencial de toxicidade (Loe et al, 1976; Fardal e Turnbull, 1986; Thylstrup e Fejerskov, 2001), não induzindo à seleção de cepas mutantes resistentes (Sreenivasan e Gaffar, 2002).

Em um estudo da área de periodontia, Auschill et al. (2005) avaliaram, in vivo, a eficácia de uma solução para bochecho à base de clorexidina a 0,2\% (Chlorhexamed) na redução do biofilme in situ, em aparelhos especiais de acrílico. Sete voluntários utilizaram diferentes aparelhos de acrílico e efetuaram 2 bochechos por dia, durante 1 minuto, por 48 horas, com a referida solução. Decorrido esse período, os aparelhos foram corados com 2 substâncias fluorescentes, que evidenciam seletivamente bactérias vivas (verdes) e mortas (vermelhas), sendo a espessura do biofilme avaliada pela microscopia confocal. Os autores concluíram que a clorexidina atuou no biofilme bacteriano in situ. Nossos resultados são concordantes com os obtidos por Auschill et al. (2005), tendo em vista que observamos diferença estatisticamente significante na quantidade de biofilme, após uso de clorexidina a 
$0,12 \%$, sob a forma de bochechos (Grupo II), nos fios $(p<0,001)$ e superfícies livres das bandas $(p<0,001)$, acrílico $(p<0,001)$ e parafuso $(p<0,001)$, em comparação ao Grupo I (controle), evidenciando a eficácia desse procedimento.

Nossos resultados são concordantes também com os obtidos por Lessa et al. (2007) e Peixoto (2007), que utilizaram a solução de gluconato de clorexidina a $0,12 \%$ (Periogard ${ }^{\circledR}$ ) para desinfecção da base de resina acrílica de aparelhos removíveis. No trabalho de Lessa et al. (2007) a clorexidina foi borrifada no aparelho uma única vez, pelo pesquisador. Por outro lado, Peixoto (2007) avaliou 2 protocolos domiciliares de uso da clorexidina, borrifada nos aparelhos uma ou duas vezes por semana, pelo paciente. Em ambos os trabalhos a clorexidina foi eficaz na redução numérica de contagem de colônias/biofilmes de estreptococos do grupo mutans na superfície do acrílico de aparelhos removíveis, em $100 \%$ dos casos, como também ocorreu no presente estudo, nas superfícies livres da resina em todos os espécimes do grupo II.

Concordamos com Chin et al. (2007) quando relatam que o uso da clorexidina é um procedimento válido para manutenção da saúde bucal de pacientes sob tratamento ortodôntico.

No entanto, por se tratar de um aparelho fixo, no presente estudo a solução de gluconato de clorexidina a $0,12 \%$ (Periogard ${ }^{\circledR}$ ) não teve acesso à resina acrílica nas superfícies não-livres do grupo II, que se encontrava em íntimo contato com a mucosa palatina, não apresentando diferença estatisticamente significante $(p=0,999)$ quando comparada aos valores do grupo I (controle). Isso possivelmente pode ser explicado pelo íntimo contato dessas áreas do aparelho com as estruturas anatômicas da cavidade bucal, dificultando a ação tanto da higienização mecânica (escovação) quanto da clorexidina.

Paralelamente, a pigmentação dental é um efeito colateral conhecido dos produtos contendo clorexidina (Löe e Schiott, 1970; Flotra et al., 1971; Gjermo, 1974; Brightman et al., 1991; Beyth et al., 2003) e sua ocorrência tem sido evidenciada in vitro (Addy et al., 1989) e in vivo (Jenkins et al., 1993). No estudo de Olympio et al. (2006), embora a pigmentação tenha sido observada pelos pesquisadores após o uso de dentifrício contendo 0,95\% de clorexidina por períodos de 6 a 24 meses, a maior parte dos voluntários não percebeu essa pigmentação. Nossos resultados são concordantes com os relatados por esses autores, pois embora tenhamos observado uma leve pigmentação na área da resina composta e dos dentes dos pacientes após o término do estudo, essa pigmentação não foi notada ou percebida pelos voluntários. 
Esses resultados nos permitem inferir que os bochechos com gluconato de clorexidina a $0,12 \%$, do ponto de vista clínico, apresentam eficácia em todas as superfícies dos aparelhos que se encontram fisicamente expostas à ação do agente antimicrobiano, podendo ser indicados como coadjuvante à escovação dental. No entanto, em áreas de mais difícil acesso, tanto a escovação quanto o agente antimicrobiano não tiveram ação.

\subsection{Dos Resultados da avaliação da presença de corrosão in situ - Estereomicroscopia ótica, Microscopia Eletrônica de Varredura e Espectrometria de Energia Dispersiva (EDS)}

A corrosão é definida como uma reação, química ou eletroquímica, entre um material, normalmente um metal, e o ambiente, produzindo deterioração do material e de suas propriedades. A maioria dos biomateriais expostos aos fluidos corporais estão sujeitos à corrosão, por meio de um processo eletroquímico com reação de oxidação. Tendo em vista que apenas o ouro puro e a platina são estáveis sob quase todas as condições, os materiais metálicos utilizados para confecção de aparelhos ortodônticos, quando colocados na cavidade bucal, podem sofrer corrosão (Geis-Gerstorfer, 1994). Ressalta-se que os aços inoxidáveis são altamente resistentes à corrosão em uma variedade de ambientes, especialmente na atmosfera. No aço, o cromo (Cr) é o elemento de liga (Callister Jr, 2002).

Em Odontologia, dentre os fatores mais importantes que afetam a escolha de metais e ligas odontológicas encontram-se a biocompatibilidade, as propriedades mecânicas e a resistência à corrosão (Ferreira, 2005). Atualmente, estudos da resistência à corrosão de fios e brackets ortodônticos compostos e/ou revestidos por aço-inox, níquel-titânio, titânio e cobre-níquel-titânio têm sido desenvolvidos, com o objetivo de encontrar o material de maior biocompatibilidade com o meio bucal (Kim et al., 1999; Lin et al., 2006; Darabara et al., 2007; Siargos et al., 2007). Porém, a maioria dos trabalhos são realizados in vitro, com saliva artificial e metodologia para simulação do meio bucal, com resultados que não podem ser extrapolados para situações clínicas.

Os metais em contato com fluidos bucais por um longo período de tempo apresentam em suas superfícies a formação de produtos de corrosão coloridos, ou seja, manchas de colorações variadas. Em 1982, Maijer e Smith avaliaram doze casos clínicos de pacientes com higiene bucal moderada/inadequada observando um predomínio de manchas na base dos brackets, possivelmente em função do ambiente ácido produzido pelos microrganismos do biofilme, o que poderia alterar o ambiente de uma situação passiva 
estável para uma condição mais propensa à corrosão. No presente estudo in situ, alterações de coloração em estereomicroscopia ótica, sugestivas da presença de corrosão, foram observadas na área de união fio/solda/banda, em ambos os grupos I e II, sem diferença estatística $(p=1)$.

A deterioação dos aparelhos ortodônticos tem se tornado um aspecto crítico na pesquisa em Ortodontia, devido às potenciais reações biológicas adversas associadas principalmente ao níquel (Bass et al., 1993; Dunlap et al., 1989). Recentemente, esse tópico ganhou mais importância em função das evidências que sugerem uma associação do níquel com a progressão da síndrome da fadiga crônica (Marcusson et al., 1999). Pacientes com essa síndrome apresentam uma alta freqüência de anomalias do sistema imune, incluindo alergia ao níquel (Wataha et al., 1997, 1999; Kohilas et al., 1999).

A maioria dos estudos in vivo tem avaliado a ocorrência da corrosão nos diferentes acessórios ortodônticos com conseqüente liberação de níquel (Eliades et al., 2000, 2002; Fors e Persson, 2006) ou níquel e cromo (Keruso et al., 1997; Agaoglu et al., 2001), que são íons também com efeitos dermatológicos, toxicológicos e mutagênicos. $O$ níquel é o metal mais comum causador das dermatites alérgicas de contato enquanto o cromo é o agente etiológico em casos de alergia em 10\% dos homens e 3\% das mulheres (Norseth, 1981; Keruso et al., 1997).

A liberação de níquel na cavidade bucal de pacientes sob tratamento ortodôntico pode ser originada de fios de níquel-titânio, de fios de aço inoxidável e de brackets de aço, entre outros (Veien et al.,1994; Lindsten e Kurol, 1997; Grimsdottir et al.,1992). Até o momento os trabalhos demonstram que há liberação de íons níquel e cromo para o meio de contato, porém tanto in vitro (Barret et al., 1993; Darabara et al., 2007) quanto in vivo (Keruso et al., 1997; Agaoglu et al.,2001; Eliades et al., 2000, 2002; Fors e Persson, 2006) os valores liberados não alcançaram níveis tóxicos destes metais, tanto na saliva quanto no soro, sendo semelhantes àqueles encontrados em indivíduos saudáveis.

No presente estudo em EDS, não foram observados picos de níquel in situ, nas regiões de solda dos aparelhos disjuntores de Haas, utilizados por aproximadamente 4 meses, em nenhum dos espécimes, de ambos os grupos. Esses resultados in situ são concordantes com os obtidos in vivo por Kerosuo et al. (1997), que avaliaram a concentração de níquel e cromo na saliva de pacientes, evidenciando que os aparelhos ortodônticos utilizados por até 30 dias não aumentaram significantemente o nível geral das concentrações de níquel e cromo na saliva.

A Espectrometria de Energia Dispersiva é um método de avaliação que qualifica quimicamente a composição do material em avaliação, sendo um método 
complementar na avaliação da presença de corrosão (Kim et al., 1999; Eliades et al., 2004; Gioka et al., 2004; Siargos et al., 2007). Em condições ideais, os picos de Fe e Cr na área de solda devem ser altos e equivalentes. Gráficos com altos picos de $\mathrm{Fe}$ e médios picos de $\mathrm{Cr}$ e presença de $\mathrm{O}$ sugerem a ocorrência de processo corrosivo pela formação de óxido férrico $\left(\mathrm{Fe}_{2} \mathrm{O}_{3}\right)$ ou óxido de ferro hidratado $\left(\mathrm{Fe}_{2} \mathrm{O}_{3} \times \mathrm{H} 2 \mathrm{O}\right.$ ), indicando ferrugem (Kuzy et al., 2002; Darabara et al., 2007). A presença de $\mathrm{P}$ com altos picos de Fe e médios picos de Cr sugere a ocorrência de processo corrosivo, pela formação de fosfato de ferro $\left(\mathrm{FePO}_{4}\right)$ (Vinnichenko et al., 2003). Esses picos foram observados na área de solda, em todos os espécimes de ambos os grupos.

No presente estudo, os picos de C (carbono) observados foram maiores nos espécimes do Grupo I, possivelmente em função da maior presença de biofilme bacteriano. Picos do elemento $\mathrm{P}$ (fósforo) foram muito expressivos nas amostras, possivelmente proveniente da saliva e/ou do cimento fosfato de zinco utilizado na cimentação das bandas de todos os aparelhos, nesse estudo. A presença dos picos de Ag nos gráficos de áreas da solda distantes das falhas entre os materiais em contato sugerem apenas a composição da liga, sem presença de corrosão.

Nossos resultados em EDS são concordantes com os obtidos em 2005 por Ferreira, que avaliou in vitro a resistência à corrosão de materiais metálicos utilizados em aparelhos ortodônticos fixos com arcos ortodônticos pré-contornados de aço inoxidável, cromo-níquel, níquel-titânio (superelástico e termoativado) e titânio-beta (titânio-molibdênio - TMA - GAC). Ensaios eletroquímicos, curvas de polarização anódica e corrente $x$ tempo, foram realizados, seguidos por avaliação em microscopia ótica, MEV e EDS. O autor concluiu que os aparelhos ortodônticos fixos apresentaram resistência ao processo corrosivo, apesar da diversidade de materiais empregados na sua composição. A corrosão foi constatada somente na região onde a solda a ponto foi utilizada para fixar o tubo terminal na banda molar, ambos materiais constituídos de aço inoxidável.

Finalizando, a análise dos resultados obtidos no presente estudo in situ, nos permitiu verificar a eficácia do uso da solução do gluconato de clorexidina a $0,12 \%$ $\left(\right.$ Periogard ${ }^{\circledR}$ ) na formação do biofilme in situ em aparelhos Disjuntores de Haas, particularmente nas superfícies livres, expostas à ação da clorexidina, sem influenciar a presença de corrosão. Tendo em vista que a Odontologia atual encontra-se na era da Promoção de Saúde, estudos adicionais são necessários, a fim de idealizar e avaliar protocolos que possibilitem, do ponto de vista clínico, o controle do biofilme formado nas superfícies não-livres, em contato com a mucosa ou com o sulco gengival, de pacientes portadores de aparelhos ortodônticos fixos. 


\section{Conclusão}




\section{Conclusão}

Com base nas metodologias empregadas (Cultura Microbiana, Microscopia Eletrônica de Varredura, Estereomicroscopia Ótica e Espectrometria de Energia Dispersiva) e nos resultados obtidos nas condições específicas deste estudo clínico randomizado, pôde-se concluir que:

- As diferentes superfícies dos aparelhos disjuntores de Haas (acrílico, bandas, parafusos expansores e fios) apresentaram intensa contaminação in situ por estreptococos do grupo mutans, em $100 \%$ dos casos no Grupo I (controle).

- $\mathrm{O}$ uso do gluconato de clorexidina a $0,12 \%$, sob a forma de bochechos (Grupo II), foi eficaz no controle da contaminação microbiana das superfícies livres (voltadas para a cavidade bucal) dos aparelhos fixos. No entanto, nas áreas do acrílico e do parafuso voltadas para o palato, e nas áreas intra-sulculares das bandas, a clorexidina não apresentou resultados satisfatórios, evidenciando a necessidade de estudos adicionais.

- Alterações de coloração e nos picos dos elementos químicos sugestivas de corrosão foram observadas nos espécimes de ambos os Grupos (I e II), na área da união entre o fio, a solda de prata e a banda dos aparelhos, sem diferença entre os grupos, evidenciando que o uso da clorexidina não influenciou na presença de corrosão in situ. 


\section{REFERENCIAS}




\section{REFERÊNCIAS*}

1. Addy M, Wade WG, Jenkins S, Goodfield S. Comparison of two commercially available chlorhexidine mouthrinses: I. Staining and antimicrobial effects in vitro. Clin Prev Dent. 1989;11(5):10-4.

2. Addy M. Chlorhexidine compared with other locally delivered antimicrobials. A short review. J Clin Periodontol 1986;13(10):957-64.

3. Agaoglu, G., Arun, T., Izgü, B., et al. Nickel and chromium levels in the saliva and serum of patients with fixed orthodontic appliances. Angle Orthod 2001;71:375 - 379 . Erratum in: Angle Orthod 2002;72:377.

4. Ahn SJ, Kho HS, Lee SW, Nahm DS. Roles of salivary proteins in the adherence of oral streptococci to various brackets. J Dent Res. 2002;81(6):411-5.

5. Ahn SJ, Lim BS, Lee SJ. Prevalence of cariogenic streptococci on incisor brackets detected by polymerase chain reaction. Am J Orthod Dentofacial Orthop 2007;131:736-41.

6. Ahn SJ, Lim BS, Lee SW, Nahm DS. Quantitative determination of adhesion paterns of cariogenis streptococci to various orthodontic adhesives. Angle Orthodontist. 2006; 76(5):869-75.

7. Ahn SJ, Lim BS, Yang HC, Chang Y-II. Quantitative analysis of the adhesion of cariogenic streptococci to orthodontic metal brackets. Angle Orthodontist. 2005; 75:666-71.

8. Ajdic D, McShan WM, McLaughlin RE, Savis G, Chang J, Carson MB et al. Genome sequence of Streptococcus mutans UA 159, a cariogenic dental pathogen. PNAS 2002;99:14434-9.

9. Anderson GB, Bowden J, Morrison EC, Caffesse RG. Clinical effects of chlorhexidine mouthwashes on patients undergoing orthodontic treatment. Am J Orthod Dentofacial Orthop 1997;111(6):606-12.

10. Anhoury P, Nathanson D, Hughes CV, Socransky S, Feres M, Chou LL. Microbial profile on metallic and ceramic bracket materials. Angle Orthodontist 2002; 72(4): 338-43.

11. Arendorf T, Addy M. Candidal carriage and plaque distribution before, during and after removable orthodontic appliance therapy. J Clin Periodontol. 1985;12:360-8.

12. Ärtun J, Brobakken BO. Prevalence of carious white spots after orthodontic treatment with multibonded appliances. Eur J Orthod. 1986;8(4):229-34.

\footnotetext{
* Normas internas do Programa de Pós-Graduação em Odontopediatria da FORP/USP(2003), de acordo com o International Committee of Medical Journal Editors. Uniform requiriments for manuscripts submited by Medical Journal, 1997. Disponível em : <http//www.mja.com.au/public/information/uniform.htm/>. Acesso em 16 de junho de 2003, e com a Associação Brasileira de Normas Técnicas - NBR 6023,ago.2002.
} 
13. Auschill TM, Hein M, Hellwig E, Follo M, Scullean A, Arweiler NB. Effect of two antimicrobials agents on early in situ biofilms formation. J Clin Periodontol. 2005; 32: 147-52.

14. Azevedo RVP. O emprego da bacteriocinotipagem (mutacinotipagem) no rastreamento epidemiológico de estreptococos do grupo mutans [tese]. São Paulo: FO - Univ. de São Paulo; 1988.

15. Badawi $H$, Evans RD, Wilson M, Ready D, Noar JH, Pratten J. the effect of orthodontic bonding materials on dental plaque accumulation and composition in vitro. Biomaterials 2003; 3345-50.

16. Barrett RD, Bishara SE., Quinn JK. Biodegradation of orthodontic appliances. Part I. Biodegradation of nickel and chromium in vitro. Am.J.Orthod. Dentofacial Orthop., 1993;103:8-14.

17. Basdra EK, Huber $\mathrm{H}$, Komposch G. Fluoride released from orthodontic bonding agents alters the enamel surface and inhibits enamel demineralization in vitro. Am J Orthod Dentofacial Orthop. 1996;109(5):466-72.

18. Bass JK, Fine $\mathrm{H}$, Cisneros GJ. Nickel hypersensitivity in the orthodontic patient.Am J Orthod Dentofacial Orthop 1993;103(3):280-5.

19. Bergman M. Corrosion in the oral cavity - potential local and systemic effects. International Dental Journal, 1986;36:41-4.

20. Berkowitz RJ. Causes, treatment and prevention early childhood caries: a microbiology prespective. J Can Dent Assoc 2003;69:304-7.

21. Beyth N. Redlich M, Harari O, Friedman M, Steinberg D.Effect of sustained-release chlorhexidine varnish on Streptococcus mutans and Actinomyces viscosus.jn orthodontic patients. Am J Orthod Dentofacial Orthop. 2003;123:345-348.

22. Bolan M, Ferreira MC, Almeida IC, D'Agostini Derech C, Ribeiro GL. Palatal expansion and the Klippel-Trenaunay-Weber syndrome. Am J Orthod Dentofacial Orthop 2005;128(3):385-7.

23. Brantley WA, Eliades T. Orthodontic materials: scientific and clinical aspects. Stuttgart: Thieme 2001;271-86.

24. Brêtas SM, Macari S, Elias AM, Ito IY, Matsumoto MAN. Effect of 0,4\% stannous fluoride gel on Streptococci mutans in relation to elastomeric rings and steel ligatures in ortjodontic patients. J Orthod Dentofacial Orthop. 2005; 127:428-33.

25. Brightman , Terezhalmy GT, Greenwell H, Jacobs M, Endlow DH. The effects of a 0.12 per cent chlorhexidine gluconate mouthrinse on orthodontic patients aged 11 through 17 with established gingivitis. Am J Orthod Dentofacial Orthop.1991;100:324-329.

26. Callister Jr WD. Ciência e Engenharia de Materiais: uma introdução. $5^{a}$ ed., Editora LTC, 2002, 589p. 
27. Cameron CG, Franchi L, Baccetti T, McNamara JA Jr. Long-term effects of rapid maxillary expansion: a posteroanterior cephalometric evaluation. Am J Orthod Dentofacial Orthop 2002; 121(2):129-35.

28. Cesco RT, Bignelli P, Santos CP, Ito IY. Toothbrushes: avaluation of contamination level by streptococci of mutans group. In: WORLD CONGRESS ON PREVENTIVE DENTISTRY, 5 ${ }^{\text {TH}} ;$ 1995, São Paulo. Proceedings... São Paulo,1995.p. 103.

29. Chin MY, Sandham A, de Vries J, van der Mei HC, Busscher HJ. Biofilm formation on surface characterized micro-implants for skeletal anchorage in orthodontics.Biomaterials. 2007;28(11):2032-40.

30. Chin MYH, Busscher HJ, Evans R, Noar J, Pratten J. Early biofilm formation and effects of antimicrobial agents on orthodontic bonding materials in a parallel plate flow chamber. European Journal of Orthodontics 2006;28:1-7.

31. Chung $\mathrm{CH}$, Font B. Skeletal and dental changes in the sagittal, vertical, and transverse dimensions after rapid palatal expansion. Am J Orthod Dentofacial Orthop2004;126(5):569-75.

32. Darabara MS, Bourithis LI, Zinelis S, Papadimitriou GD. Metallurgical characterization, galvanic corrosion, and ionic release of orthodontic brackets coupled with $\mathrm{Ni}-\mathrm{Ti}$ archwires. J Biomed Mater Res Part B Appl Biomater 2007;81(1):126-34.

33. Davenport JC. The denture surface. Br Dent J. 1972;133:101-5.

34. Davey AL, Rogers AH. Multiple tipes of the bacterium Streptococccus mutans in the human mouth and their intra family transmission. Arch Oral Biol 1984; 29: 453-60.

35. Decker EM, von Ohle $C$, Weiger $R$, Wiech I, Brecx M. A synergistic chlorhexidine/chitosan combination for improved antiplaque strategies.J Periodontal Res. 2005;40(5):373-7.

36. Diedrich P. Microbial colonisation and various cleaning procedures for orthodontic appliances. Fortschr Kieferorthop 1989;50:231-9.

37. Dills SS, Olshan AM, Goldner S, Brogdon C. Comparison of the antimicrobial capability of an abrasive paste and chemical-soak denture cleaners. J Prosthet Dent. 1988;60(4):467-70.

38. Dogan A, Bek B, Cevik NN, Usanmaz A. The effect of preparation conditions of acrylic denture base materials on the level of residual monomer, mechanical properties and water absorption. J Dent 1995;23(5):313-8.

39. Dunlap CL, Vincent SK, Barker BF. Allergic reaction to orthodontic wire: report of case. J Am Dent Assoc 1989;118(4):449-50.

40. Eliades $T$, Athanasiou A.E. In vivo aging of orthodontic alloys: implications for corrosion potential, nickel release, and biocompatibility. Angle Orthod 2002;72(3):222 - 237.

41. Eliades $T$, Eliades $G$, Athanasiou AE, Bradley TG. Surface characterization of retrieved NiTi orthodontic archwires. Eur J Orthod 2000;22(3):317-26. 
42. Eliades $T$, Eliades $G$, Watts DC. Intraoral aging of the inner headgear component: a potential biocompatibility concern? Am J Orthod Dentofacial Orthop 2001;119(3):3006.

43. Eliades T, Zinelis S, Papadopoulos MA, Eliades G, Athanasiou AE. Nickel content of asreceived and retrieved $\mathrm{NiTi}$ and stainless steel archwires: assessing the nickel release hypothesis. Angle Orthod. 2004;74(2):151-4.

44. Emilson CG. Susceptibility of various microorganisms to chorhexidine. Scand J Dent Res. 1977; 85: 255-65.

45. Fardal O, Turnbull RS. A review of the literature on use of chlorhexidina in dentistry. Journal of America Dental Association 1986; 112: 863.

46. Fardal O, Turnbull RS. A review of the literature on use of chlorhexidina in dentistry. Journal of America Dental Association 1986; 112: 863.

47. Featherstone JDB. Delivery challenges for fluoride, chlorhexidine and xylitol. BMD Oral Health 2006; 15;6 Suppl 1:S8.

48. Fejerskov O, Kidd E. Cárie Dentária. A doença e seu tratamento clínico. São Paulo: Ed Santos, 2005.

49. Ferreira J.T.L. Avaliação da resistência à corrosão de materiais metálicos utilizados em aparelhos ortodônticos fixos.[Tese de doutorado]. Rio de Janeiro:UF R], 2005.

50. Fletcher RH, Fletcher SW, Wagner EH. Epidemiologia clínica: elementos essenciais. $3^{\mathrm{a}}$ ed. Porto Alegre: Artmed; 2002.

51. Flotra L, Gjermo P, Rolla G, Waerhaug J. Side effects of chlorhexidine mouth washes.Scand J Dent Res. 1971;79(2):119-25.

52. Fors $R$, Persson M. Nickel in dental plaque and saliva in patients with and without orthodontic appliances. Eur J Orthod. 2006;28(3):292-7.

53. Fulford MR, Ireland AJ, Main BG. Decontamination of tried-in orthodontic molar bands. European Journal of Orthodontics 2003; 25: 621-2.

54. Geis-Gerstorfer J. In vitro corrosion measurements of dental alloys. Journal of Dentistry, 1994; 22:247-51.

55. Gioka C, Bourauel C, Zinelis S, Eliades T, Silikas N, Eliades G. Titanium orthodontic brackets: structure, composition, hardness and ionic release. Dent Mater. 2004 Sep;20(7):693-700.

56. Gjermo P. Chlorhexidine in dental practice. J Clin Periodontol. 1974; 1: 143-52.

57. Gold OJ, Jordan HV, van Houte JA. Seletive medium for Streptococccus mutans. Arch Oral Biol 1973; 18:1357-64.

58. Gorelick $L$, Geiger AM, Gwinnett AJ. Incidence of white spot formation after bonding and banding. Am J Orthod 1982; 81:93-8. 
59. Graber T.M. Principles and Practice. Philadelphia: W.B.Saunders Co; 1966.

60. Grimsdottir MR, Gjerdet NR, Hensten-Pettersen A. Composition and in vitro corrosion of orthodontic appliances. Am J Orthod Dentofacial Orthop 1992;101(6):525-32.

61. Gwinnett AJ, Ceen RF. Plaque distribution on bonded brackets: a scanning microscope study. Am J Orthod 1979;75(6):667-77.

62. Haas A.J. Palatal expansion: Just the beginning of dentofacial orthopedics. Am J Orthod 1970; 57:.219-255.

63. Handelman CS, Wang L, BeGole EA, Haas AJ. Nonsurgical rapid maxillary expansion in adults: report on 47 cases using the Haas expander. Angle Orthod.2000;70(2):129-44.

64. Hidalgo E, Dominguez C. Mechanisms underlying chlorhexidine induced citotoxity. Toxicol in Vitro 2001;15: 271-6.

65. Huang $\mathrm{HH}$. Surface characterizations and corrosion resistance of nickel-titanium orthodontic archwires in artificial saliva of various degrees of acidity. J Biomed Mater Res A 2005;74(4):629-39.

66. Huser MC, Baehni PC, Lang R. Effects of orthodontic bands on microbiologic and clinical parameters. Am J Orthod Dentofacial Orthop 1990;97:213-8.

67. Hwang C, Shin J, Cha J. Metal release from simulated fixed orthodontic appliances. Am J Orthod Dentofacial Orthop 2001;120(4):383-390.

68. Iijima M, Endo K, Yuasa T, Ohno H, Hayashi K, Kakizaki M, Mizoguchi I. Galvanic corrosion behavior of orthodontic archwire alloys coupled to bracket alloys. Angle Orthod. 2006;76(4):705-11.

69. Ito IY, Alburquerque Jr RF, Alonso Verri R. Estreptococos: modificação na técnica de identificação das cepas isoladas da cavidade oral. In: JORNADA ODONTOLÓGICA DE RIBEIRÃO PRETO,15aa,1993, Ribeirão Preto. Anais... Ribeirão Preto: USP, 1993.p.5.

70. Jagger DC, Harrison A, Jandt KD. The reinforcement of dentures. J Oral Rehabil. 1999;26(3):185-94.

71. Jenkins S, Addy M, Newcombe R. Evaluation of a mouthrinse containing chlorhexidine and fluoride as an adjunct to oral hygiene. J Clin Periodontol. 1993 Jan;20(1):20-5.

72. Jensen B, Bratthall D. Anew method for estimation of mutans streptococci in human saliva, J Den Res 1989;68:468-71.

73. Jones CG. Chorhexidine: is it still the gold standard? Periodontol 2000 1997; 15:55-62.

74. Jordan C, Leblanc DJ. Influences of orthodontics appliances on oral populations of mutans streptococci, Oral Microbiol Immunol 2002;17:65-71. 
75. Jorge AOC, Almeida NQ, Unterkircher CS, Schimizu MI. Influência do uso dos aparelhos ortodônticos sobre a presença da Cândida albicans na cavidade bucal. Rev APCD 1987;41:308-10.

76. Kao CT, Ding SJ, He H, Chou MY, Huang TH. Cytotoxicity of orthodontic wire corroded in fluoride solution in vitro. Angle Orthod 2007;77(2):349-54.

77. Kara D, Luppens SBI, ten Cate JM. Differences between single and dual species biofilms of Streptococcus mutans and Veillonella parvula in growth, acidogenicity and susceptibility to chlorhexidine. Eur j Oral Sci 2006;14:58-63.

78. Kedici SP, Aksut AA, Kilicarslan MA, Bayramoglu G, Gokdemir K. Corrosion behaviour of dental metals and alloys in different media. J Oral Rehabil. 1998;25(10):800-8.

79. Kerusuo M., Moe, G. Hensten-Pettersen, A. Salivary nickel and chromium in subjects with different types of fixed appliances. Am. J. Orthod. Dentofacial Orthop. 1997; 111:595 - 598.

80. Kim H, Johnson JW. Corrosion of stainless steel, nickel-titanium, coated nickel-titanium and titanium orthodontic wires. Angle Orthod 1999;69:39-44.

81. Kohilas K, Lyons M, Lofthouse R, Frondoza CG, Jinnah R, Hungerford DS. Effect of prosthetic titanium wear debris on mitogen-induced monocyte and lymphoid activation. J Biomed Mater Res 1999;47(1):95-103.

82. Kolahi J, Soolari A. Rinsing with chorhexidine gluconate solution after brushinh and flossing theeth: a systematic review of effectiveness. Quintessence international 2006;37(8):605-12.

83. Kuzy RP, Ambrose WW, La Vanier LA, Newman JG, Whitley JQ. Analyses of rampant corrosion in stain-steel retainers of orthodontic patients. J Biomed Mater Res 2002;62:106-108.

84. Lessa FC, Enoki C, Ito IY, Faria G, Matsumoto MA, Nelson-Filho P. In-vivo evaluation of the bacterial contamination and disinfection of acrylic baseplates of removable orthodontic appliances. Am J Orthod Dentofacial Orthop 2007 Jun;131(6):705.e11-7.

85. Leung NM, Chen R, Rudney JD. Oral bacteria in plaque and invading bucal cells young orthodontic patients. Am J Orthod Dentofacial Orthop. 2006;130:698.e18.

86. Lima AL, Lima Filho RM, Bolognese AM. Long-term clinical outcome of rapid maxillary expansion as the only treatment performed in Class I malocclusion. AngleOrthod 2005;75(3):416-20.

87. Lin $\mathrm{MC}$, Lin $\mathrm{SC}$, Lee $\mathrm{TH}$, Huang $\mathrm{HH}$. Surface analysis and corrosion resistance of different stainless steel orthodontic brackets in artificial saliva. Angle Orthod 2006;76(2):322-9.

88. Lindsten $\mathrm{R}$, Kurol J. Orthodontic appliances in relation to nickel hypersensitivity. A review. J Orofac Orthop 1997;58(2):100-8. 
89. Löe $H$, Schiott CR, Glavind L, Kaning T. Two years oh use of chlorhexidine in man. Genrral design and effects. J Periodont Res. 1976;11:135-4.

90. Löe $H$, Schiott CR. The effect of mouthrinses and topical application of chlorhexidine on the development of dental plaque and gingivitis in man. J Periodontal Res. $1970 ; 5(2): 79-83$.

91. Loesche WJ. Role of Streptococcus mutans in human dental decay. Microbiol Rev 1986;50:353-380.

92. Lundström $\mathrm{F}$, Hamp SE, Nyman S. Systematic plaque control in children undergoing long-term orthodontic treatment. Eur J Orthod. 1980;2(1):27-39.

93. Macpherson LMD, MacFarlane TW, Stephen KW. An intra-oral appliance study of the plaque microflora associated with early enamel demineralization. J Dent Res 1990; 69(11):1712-1716.

94. Magno AFF, Enoki C, Ito IY, Matsumoto MAN, Faria G, Nelson-Filho P. in vivo evaluation of contamination of super slick elastomeric rings by mutans streptococci in orthodontics patients. Am J Orthod Dentofacial Orthoped. 2007; in press.

95. Maijer R, Smith DC. Corrosion of orthodontic bracket bases. Am. J. Orthod 1982;81: 43-81982.

96. Marcusson JA, Lindh G, Evengard B. Chronic fatigue syndrome and nickel allergy. Contact Dermatitis. 1999;40(5):269-72.

97. Marsh PD. Dental plaque as a biofilm and a microbial community - implications for health and disease. BMC Oral Health 2006; 6 (Suplemento 1): S14.

98. Martins-Ortiz MF, Freitas PZ, Nelson-Filho P, Consolaro A. Por que se preocupar com a higienização dos aparelhos? Dental Press Orthodon Ortop Facial 2004;9:30-32.

99. Mattingly JA, Sauer GJ, Yancey JM, Arnold RR. Enhancement of Streptococcus mutans colonization by direct bonded orthodontic appliances. J Dent Res 1983;62:1209-11.

100. Mc Neill K, Hamilton IR. Acid tolerance response of biofilms cells of Streptocococs mutans. FEMS Microbiol Lett 2003;221: 25-30.

101. Mitchell L. Decalcification during orthodontic treatment with fixed appliances - an overview. Br J Orthod 1992;19:199-205.

102. Mizahi E. Enamel demineralization following orthodontic treatment. Am J Orthod 1982;82:62-67.

103. Morrow D, Wood DP, Speechley M. Clinical effect of subgingival chlorhexidine irrigation on gingivitis in adolescent orthodontic patients. Am J Orthod Dentofacial Orthop 1992;101(5):408-13.

104. Moshrefi A. Chlorhexidine. J West Soc Periodontol Periodontal Abstr 2002; 50:5-9.

105. Naranjo AA, Triviño $M L$, Jaramillo $A$, Betancourth $M$, Botero JE. Changes in the subgingival microbiota and periodontal parameters before and 3 months after bracket placement. Am J Orthodontics and Dentofacial Orthopedics 2006; 130:275.e17275.e22. 
106. Nelson Filho P, Isper AR, Assed S, Faria G, Ito IY. Effect of triclosan dentifrice on toothbrush contamination. Pediatric Dentistry, 2004;26(1):11-16.

107. Nelson-Filho P, Faria G, Silva RAB, Rossi MA, Ito IY. Evaluation of the contamination and disinfection methods of toothbrushes used by 24 -to- 48-month - old children. Journal of Dentistry for children 2006; 73:3.

108. Norseth T. The carcinogenicity of chromium. Environ Health Perspect 1981;40:121-30.

109. Ogaard B, Larsson E, Henriksson T, Birkhed D, Bishara SE. Effects of combined application of antimicrobial and fluoride varnishes in orthodontic patients. Am J Orthod Dentofacial Orthop 2001;120:279.

110. Ogaard B, Rolla G, Arends J, ten Cate JM. Orthodontic appliances and enamel demineralization. Part 2. Prevention and treatment of lesions. Am J Orthod Dentofacial Orthop 1988;94:1238.

111. O'Hoy PY, Messer HH, Palamara JE. The effect of cleaning procedures on fracture properties and corrosion of NiTi files. Int Endod J 2003;36(11):724-32.

112. Oliveira NL, Da Silveira AC, Kusnoto B, Viana G. Three-dimensional assessment of morphologic changes of the maxilla: a comparison of 2 kinds of palatal expanders. Am J. Orthod Dentofacial Orthop.2004; 126(3):354-62.

113. Olympio KP, Bardal PA, de M Bastos JR, Buzalaf MA. Effectiveness of a chlorhexidine dentifrice in orthodontic patients: a randomized-controlled trial. J Clin Periodontol. 2006;33(6):421-6.

114. Olympio KPK, Bardal PAP, de M Bastos JR, Henreques JFC, Cardoso VES, Silva PA, Bardal PAP \& Ramires I. Caries y enfermidad periodontalcausadas por tratamiento ortodóntico en ausencia de un programa educativo-perventivo. Revista Odontológica Dominicana 2003;9:31-38.

115. Parson JC. Chemoterapy of dental plaque - a review. J Periodontol 1974; 45: 177-86.

116. Peixoto, ITA. Avaliação de protocolos clínicos para a desinfecção de aparelhos ortodônticos removíveis (cultura microbiana e MEV). [dissertação]. Ribeirão Preto: FORP - Univ. de São Paulo; 2007.

117. Pratten J, Smith AW, Wilson M. Response of single species biofilms and microcosm dental plaques to pulsing with chlorhexidine. J Antimicrob Chemother. 1998 Oct; 42(4):453-9.

118. Rolla $G$, Melsen $B$. The mechanism of the plaque inhibition by chlorhexidine. J Dent Res 1975;54:57-62.

119. Rosa EA, Rached RN, Tanaka O, Fronza F, Fronza F, Araujo Assad R. Preliminary investigation of bacteremia incidence after removal of the Haas palatal expander.Am J Orthod Dentofacial Orthop. 2005 Jan;127(1):64-6. 
120. Rosenbloom RG, Tinanoff N. Salivary Streptococcus mutans levels in patients before, during, and after orthodontic treatment. Am J Orthod Dentofacial Orthop. 1991;100:35-7.

121. Sanches MH, Peres SHCS, Peres AS, Bastos JRM. Descontaminação das escovas dentais por imersão em soluções anti-sépticas. RGO 2001;49:167-71.

122. Sato S, Pedrazi V, Guimarães Lara EH, Panzeri $H$, Ferreira de Albuquerque RJr, Ito IY. Antimicrobial spray for toothbrush disinfection: an in vivo evaluation. Quintessence Int. 2005; 36(10):812-6.

123. Shklair IL, Keene HJ. A biochemical scheme for the separation of the five varieties of Streptococcus mutans. Arch Oral Biol $1974 ; 19: 1079-81$.

124. Siargos B, Bradley TG, Darabara M, Papadimitriou G, Zinelis S. Galvanic corrosion of metal injection molded (MIM) and conventional brackets with nickel-titanium and copper-nickel-titanium archwires. Angle Orthod 2007;77(2):355-60.

125. Silva Filho OG, Lara TS, Silva HC, Bertoz FA. Comportamento da sutura palatina mediana em crianças submetidas à expansão rápida da maxila: avaliação mediante imagem de tomografia computadorizada. Dental Press Ortodon Ortop Facial 2007;12(3):94-103.

126. Sober HÁ, Harte RA. Hanbook of biochemistry: selected data for molecular biology. Clevlend: Chemical Rubber; 1968.

127. Southard TE, Cohen ME, Ralls SA, Rouse LA. Effects of fixed-appliance orthodontic treatment on DMF indices. Am J Orthod Dentofacial Orthop. 1986;90:122-6.

128. Sreenivasan PK, Gaffar A. Antiplaque biocides and bacterial resistence: a review. J Clin Periodontol. 2002; 29:965-74.

129. Sreenivasan PK, Mattai J, Nabi N, Xu T, Gaffar A. A simple approach to examine early microbial formation biofilm and effects of treatments. Oral Microbiol Immunol 2004; 19: 297-302.

130. Steinberg D, Eyal S. initial biofilms formation of Streptococcus sobrinus on various orthodontics appliances. Journal of Oral Rehabilitation 2004; 31:1041-5.

131. Sudjalim TR, Woods MG, Manton DJ, Reynolds EC. Prevention of demineralization around orthodontic brackets in vitro. Am J Orthod Dentofacial Orthop. 2007;131(6):705.e1-9.

132. Suga $\mathrm{M}$, Torii $\mathrm{K}$, Kumihashi $\mathrm{T}$, Kakibayashi $\mathrm{H}$. Highly accurate composition analysis of $(\mathrm{Pb}, \mathrm{Zr}) \mathrm{TiO}_{3}$ Using a Scanning Electron Microscope/Energy Dispersive X-Ray Spectrometer. Jpn J Phys 2000;39:316-319.

133. Takada K, Hirasawa M. A novel selective medium for isolation of Streptococcus mutans. J Microbiol Methods. 2005;60(2):189-93.

134. Tedjosasongko $U$, Kozai $K$. Inicial acquisition and transmition of mutans streptococci in children at day nursey. J Dent Child 2002; 69:284-8. 
135. Thomazinho A, Ferreira JTL, Stuani MBS, Matsumoto MAN. In: Assed S. Odontopediatria - Bases Científicas para Prática Clínica. São Paulo: Artes Médicas; 2005.p. 879-992.

136. Thylstrup A, Fejerskov O. Cariologia Clínica. 2nd ed. São Paulo: Editora Santos; 2001.

137. Torres AS, Pizzolitto AC, Ellias AM, Ito IY. Estreptococos do grupo mutans: avaliação do ágar $\mathrm{SB}_{20}$ e $\mathrm{MSB}$ na determinação de ufc na saliva e na placa dental de adolescentes. Rev Brás Odontol 1993;50:18-21.

138. Turkkahraman H, Sayin MO, Bozkurt FY, Yetkin Z, Kaya S, Onal S. Archwire ligation techniques, microbial colonization, and periodontal status in orthodontically treated patients. Angle Orthod. 2005 Mar;75(2):231-6.

139. Ulukapi H, Koray $F$, Efes B. Monitoring the caries risk of orthodontic patients. Quintessence Int. 1997;28:27-9.

140. Veien NK, Borchorst E, Hattel T, Laurberg G. Stomatitis or systemically-induced contact dermatitis from metal wire in orthodontic materials. Contact Dermatitis 1994;30(4):210-3.

141. Vinnichenko MV, Pham MT, Chevolleau T, Poperenko LV, Maitz MF. In situ ellipsometric investigation of stai9nless steel corrosion behavior in buffered solutions with amino acids. Applied Surface Science 2003;207:176-182.

142. Wan AKL, Seonw WK, Purdie DM, Bird PS, Walsh GK, Tudehope DI. A longitudinal study of streptococos mutans colonization in infants after tooth eruption. J Dent Res 2003; 82: 504-8.

143. Wataha JC, Lockwood PE, Marek M, Ghazi M. Ability of Ni-containing biomedical alloys to activate monocytes and endothelial cells in vitro. J Biomed Mater Res. 1999;45(3):251-7.

144. Wataha JC, Sun ZL, Hanks CT, Fang DN.Effect of Ni ions on expression of intercellular adhesion. J Biomed Mater Res. 1997;36:145-51.

145. Whittenbury R. Hydrogen peroxide formation and catalase activity in the lactic acid bacteria. J Gen Microbiol. 1964;35:13-26.

146. Wichelhaus A, Brauchle G, Mertmann M, Sander FG. Corrosion of orthodontic pliers using different sterilization procedures. J Orofac Orthop 2004;65(6):501-11.

147. Zachrisson BU. Cause and prevention of damage to teeth and supporting structures during orthodontic treatment. Riv Ital Stomatol 1977;46(5):45-59.

148. Zimring JF, Isaacson RJ. Forces produced by rapid maxillary expansion. III. Forces present during retention. Angle Orthod 1969;35:178-186. 


\section{APENDICES}

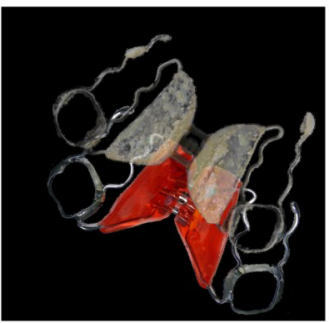




\title{
Anexo A- Aprovação do Comitê de Ética
}

\author{
UNIVERSIDADE DE SÃO PAULO \\ FACULDADE DE ODONTOLOGIA DE RIBEIRÃO PRETO \\ COMITÊ DE ÉTICA EM PESQUISA \\ Avenida do Café, $s / n^{\circ}$ - Telefone: (016) 3602-3963 \\ 14040-904 - Ribeirão Preto - SP - Brasil \\ Fax: (016) 3633-0999
}

OF.CEP/14206/FORP/29052006

Prezado(a) Professor(a),

Ref.: Processo n० 2006.1.391.58.9

De ordem da Senhora Coordenadora do Comitê de Ética em Pesquisa desta Faculdade, informamos que o referido Comitê, em sua 67 a Sessão realizada no dia 26 de maio de 2006, deliberou aprovar o Projeto de Pesquisa envolvendo seres humanos, intitulado: "Avaliação da contaminação bacteriana e da corrosão em aparelhos disjuntores de Haas.", a ser desenvolvido por Vossa Senhoria, na Faculdade de Odontologia de Ribeirão Preto, devendo o atestado para publicação final ser expedido pelo Comitê de Ética em Pesquisa, após a entrega e aprovação do Relatório Final pelo referido Comitê.

Na oportunidade, lembramos da necessidade de entregar na Secretaria do Comitê, com o formulário preenchido pelo pesquisador responsável, o Relatório Parcial no dia 31/05/07 e o Relatório Final no dia 31/05/08.

Atenciosamente,

$$
\text { caun boroce }
$$

Glauce Della Rosa

Secretária do Comitê de Ética em Pesquisa

Ilmo. Sr.

Prof. Dr. PAULO NELSON FILHO

Professor Titular do Departamento de Clínica Infantil, Odontologia Preventiva e Social - FORP/USP

GDR/gdr 


\title{
AUTORIZAÇÃO PARA REPRODUÇÃO
}

Autorizo a reprodução e/ou divulgação total ou parcial da presente obra, por qualquer meio convencional ou eletrônico, desde que citada a fonte.

\author{
Cristhiane Ristum Bagatin Rossi \\ Universidade de São Paulo \\ Faculdade de Odontologia de Ribeirão Preto \\ Departamento de Clínica Infantil, Odontologia Preventiva e Social \\ Ribeirão Preto/Julho de 2007 \\ Avenida do Café s/n - CEP 14040-904 \\ e-mail: crisbagatin@yahoo.com.br
}

